\title{
Geotechnics of municipal sludges and residues for landfilling
}

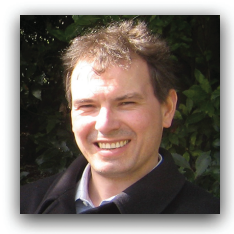

Brendan C. O’Kelly PhD, FTCD, CEnv, CEng, MICE

Associate Professor, Department of Civil, Structural and Environmental

Engineering, Trinity College Dublin, Dublin, Ireland (bokelly@tcd.ie)

This paper presents a comprehensive review of reported field and laboratory investigations and theoretical work concerning the geotechnical behaviour/properties of water treatment residue (WTR), biosolids and sewage sludge materials, which are by-products of municipal water and wastewater treatment processes. After describing the backgrounds to the generation of these materials and various disposal options (with a focus on landfilling), including associated geotechnical issues, their physical, geotechnical index, compaction, undrained strength and effective-stress strength properties are described, including the effects of oxidation, biodegradation and viscous gellike pore fluid for biosolids/sewage sludge material. Characteristic compressibility, consolidation and permeability behaviour/properties are also presented for these materials and linked with microstructure and the chemicals added during the treatment processes. The paper then focuses on various geotechnical issues pertinent to landfill (monofill) disposal of these materials, including undrained strength requirements, design strength, on-site and laboratory strength measurements and water content-strength correlations. Since such correlations are material specific, with the geotechnical properties of biosolids, sewage sludge and WTR materials varying between water/wastewater treatment plants, they cannot be applied more widely with confidence. Alternative approaches to predicting undrained strength are described, including a power-law strength relationship with water content, which can be applied more generally.

\section{Notation}

$C_{\mathrm{c}} \quad$ compression index

$c_{\mathrm{v}} \quad$ coefficient of consolidation

$c^{\prime} \quad$ cohesion intercept

$F \quad$ factor of safety

$G_{\mathrm{S}} \quad$ specific gravity of solids

$h \quad$ cone penetration depth

$I_{\mathrm{L}} \quad$ liquidity index

$K$ cone factor

$k$ permeability coefficient

$L L \quad$ liquid limit

OWC optimum water content for compaction

$P I \quad$ plasticity index

$P L \quad$ plastic limit

$R^{2} \quad$ coefficient of determination

SC solids content

$S_{\text {ur }}$

$S_{\mathrm{u}(t)}$ remoulded undrained strength

undisturbed undrained strength mobilised after time period $t$

undrained strength in triaxial compression

undrained strength in vane shear

remoulded undrained strength for water content $w_{1}$ remoulded undrained strength for water content $w_{2}$ total volatile solids

time to failure

weight of fall cone

$\begin{array}{ll}W_{\mathrm{LN}} & \text { relative water content parameter } \\ w & \text { gravimetric water content } \\ w_{\mathrm{n}} & \text { natural water content } \\ \alpha & \text { adhesion factor } \\ \mu & \text { rate dependence parameter } \\ \rho & \text { bulk density } \\ \rho_{\mathrm{d}} & \text { maximum dry density } \\ \sigma_{\mathrm{v}}^{\prime} & \text { vertical effective stress } \\ \phi^{\prime} & \text { peak effective friction angle } \\ \phi_{\mathrm{cv}}^{\prime} & \text { critical state effective friction angle } \\ \phi_{\mathrm{u}} & \text { undrained friction angle (total stress) }\end{array}$

\section{Introduction}

Main types and origin of municipal sludges and residues This paper concerns itself with the geotechnical properties and behaviour of water treatment residue (WTR), human biosolids and sewage sludge materials, which account for the vast majority of municipal sludge and residue materials produced worldwide. WTR materials are derived from the filter backwash water, chemical coagulation, flocculation, settling and water-softening processes used in the production of potable water (Ratnayaka et al., 2009). These materials usually comprise silt and clay-sized particles (typically quartz and calcite), colloidal organic matter and smaller quantities of chemicals (aluminium sulfate or ferric chloride coagulants, polyelectrolyte coagulant aids and 
conditioning agents, such as activated silica, sodium silicate, bentonite, calcium/sodium hydroxide, sulfuric acid, lime or soda ash) that are added during the treatment of the source water (O'Kelly, 2008a). The type and amount of chemicals added depends on the nature of the source water, but primarily on its turbidity and hardness. The coagulants cause the colloidal particles present to aggregate into flocs (with the polyelectrolyte also acting as a binding agent to increase their inherent shear strength) that are more readily separated out by settling processes, removing not only the impurities but also the chemical additives. The residue so formed is categorised as aluminium sulfate (alum) or iron WTR material depending on the coagulant salt, with the former being the most widely used coagulant in the water treatment industry. Lime-softening sludge, composed of typically $80-95 \mathrm{wt} \%$ calcite (Raghu and Hsieh, 1986), is the result of softening hard water before its distribution as drinking water.

Biosolids and sewage sludge materials are highly organic residue by-products of municipal waste water treatment, with the organic fraction originating principally from human faeces (primary sludge) and bacterial biomass (secondary sludge) and the inorganic fraction derived from materials such as soil, sediment and inorganic residuals (Haynes et al., 2009). According to the US Environmental Protection Agency (EPA) (2015), sewage sludge refers to the solids separated out during the treatment processes, whereas biosolids refers to treated sewage sludge material that meets regulatory pollutant- and pathogen-control requirements for land application and surface disposal. Since 'biosolids' is a more recent term (formally introduced in 1991), many materials described as sewage sludge in earlier literature may be more correctly categorised as biosolids, although sufficient information on the treatment processes employed at the different waste water treatment plants (WWTPs) is often not reported to allow definitive conclusions in this regard.

Chemical conditioning of the sludge by-products at treatment works achieves better dewatering efficiency using belt-filter press, centrifuge or other technologies, in order to reduce their mass (volume) and, consequently, reduce storage, handling and transport costs, before various disposal routes. The water content reduction achievable at treatment plants using these technologies varies, but typically lower the water content to a few hundred per cent (Metcalf and Eddy, Inc., 2004; O'Kelly and Quille, 2009), explaining why the improvement of dewatering processes is still necessary.

\section{Typical geotechnical behaviour}

Compared with most inorganic soils, dewatered biosolids, sewage sludge and WTR materials are challenging and unconventional geomaterials generally having extremely high water content, high organic matter content, low specific gravity of solids, low bulk and dry densities and extremely high plasticity. Further, they typically exhibit very low shear strength, very high compressibility, swelling and shrinkage potentials and have very to extremely low permeability (Arulrajah et al. (2011, 2013), Aydilek et al. (2000),
Chen et al. (2014), Diliūnas et al. (2010), Disfani et al. (2013, 2015), Kayser et al. (2011), Klein and Sarsby (2000), Koenig and Bari (2001), Lin et al. (2014), Lo et al. (2002), O'Kelly (2006, 2008a, 2008b, 2010, 2013a, 2014a, 2016a, 2016b), O'Kelly and Quille (2009, 2010), Wang et al. (1992), Wang and Tseng (1993), Wichmann and Riehl (1997), Zhan et al. (2014), to name a few). For landfilled material, chemicals added during the water/ wastewater treatment processes tend to enhance the strength properties but reduce the level and rate of consolidation achievable on-site (O'Kelly and Quille, 2010). According to Elliott et al. (1990), the mineralisation rates of organic carbon and nitrogen in alum WTRs are similar to those of natural soils. Biosolids and sewage sludge materials have a higher organic matter content and a propensity to degrade and produce biogas for $\mathrm{pH}<11$ (Disfani et al., 2015; Kayser et al., 2011), such that their compositions and hence engineering behaviour/properties change over time, with the rate and intensity of these changes largely governed by prevailing geoenvironmental conditions (Diliūnas et al., 2010; O'Kelly, 2005a, 2006, 2016c). Another distinctive feature of biosolids and sewage sludge materials is their viscous gel-like pore fluids produced by the high concentration of dissolved solids, high bonding or adsorption of the liquid phase within and around the aggregate flocs and some form of biological coagulation between the pore fluid and organic solids (Klein and Sarsby, 2000; O'Kelly, 2008b, 2013a; Sarsby, 2005).

\section{Management of these waste streams and principal disposal options}

The amounts of biosolids, sewage sludge and WTR materials produced annually in the world has increased dramatically over recent decades because of population growth, urbanisation, greater demand for potable water, stricter regulations on the quality of potable water and waste water discharges, and hence, the demand for new treatment plants and necessity for continuous upgrading of existing facilities. Management of these increasing amounts of sludge and residue materials is a key issue. Principal disposal options for these materials are

- indefinite storage in shallow or deep lagoons (Claydon et al., 1997; Klein and Sarsby, 2000; Lin et al. 2014; Zhan et al., 2014)

v volume reduction by mechanical and (/or) thermal means followed by landfilling, either at dedicated monofills (O'Kelly, 2004, 2005b, 2010, 2016d; Lin et al. 2014; Wang et al., 1992; Zhan et al., 2014), dedicated deposition areas at sanitary landfills (O'Kelly, 2008a) or co-disposal with municipal solid waste (MSW) in which these residue materials are usually intermixed with MSW streams (Koenig and Kay, 1995; Koenig et al., 1996; Lo et al., 2002; Loll, 1986, 1991)

- the preferred route of beneficial use as agricultural land fertiliser (Elliott et al., 1990), for composting to produce a humus-like product resembling soil, in forestry and soil redevelopment (e.g. mine reclamation)

- incineration. 
The combination of very high water and organic matter contents and very low strength, on the one hand, and high to very high potential of compacted material to deform (settle) excessively under applied loads on the other makes biosolids and sewage sludge materials problematic for use in virtually any form of construction (Kayser et al., 2011). Biosolids and sewage sludge amended with additives such as lime, fly ash, cement and (or) slag can be used as construction materials (Lim et al., 2002) - for example, as landfill cover (Chen et al., 2014; Diliūnas et al., 2010; He et al., 2015; Kim et al., 2005) or as structural fill material in road embankments (Arulrajah et al., 2013; Disfani et al., 2013, 2015; Wanigaratne and Udamulla, 2012), with special protection required in the event that there is potential for leaching/ flow to adjoining water bodies (Arulrajah et al., 2011). Alum and lime WTR has the potential for use as a liner material for sanitary landfills (Raghu et al., 1987). Potential reuse options for limesoftening sludge material include as buffer for acidic soil, as stabilising material for ground improvement, as conditioner for sewage sludge, as cover material for landfills and brownfields (Fei et al., 2016) and as engineering fill to support light loads (Raghu and Hsieh, 1986). Another option for the beneficial use of biosolids and alum WTR materials is as a partial replacement material for clay in the manufacture of fired-clay bricks (Chiang et al., 2009; Ukwatta et al., 2015, 2016).

\section{Geotechnical considerations for landfilling route}

The landfill disposal route is subject to stringent regulation, coupled with rising landfill gate costs. Difficulties in sourcing new landfill sites means that the fill height and (/or) slope angle of many existing landfills are being increased to accommodate the placement of further material (e.g. Zhan et al. (2014)). The biosolids, sewage sludge and WTR materials must be adequately dewatered at the municipal works to reduce transport and landfill-disposal costs, to gain sufficient shear strength for efficient handling, placement and trafficability requirements at the landfill site and for geotechnical stability of the landfill slopes. Greater levels of dewatering also reduce the amount of leachate subsequently generated in the landfill environment. Since the dewatered sludge and residue materials are soil-like, their behaviour in lagoons, monofills and sanitary landfills can be assessed with reasonable accuracy using soil mechanics theory and conventional on-site and geotechnical laboratory testing, provided due care and attention are given to their distinctive properties. These include the significant effect of biodegradation on the engineering behaviour/properties of landfilled biosolids and sewage sludge materials, with copious amounts of biogas generated, and must be carefully considered in the landfill design.

Pertinent regulations, including the Council of the European Communities Landfill and Waste Management Directives (EC, 1999, 2006), have tended mainly to focus on ensuring that no harmful substances from these landfills reach the biosphere or hydrosphere in unacceptable quantities, hence the importance of having efficient well-maintained biogas extraction, leachate drainage and surface water control systems in place. Co-disposal with MSW may have particular benefits to the operation of bioreactor landfills as a source of moisture, although the increase in overall liquid content and resulting increase in pore pressure and decrease in shear strength can significantly reduce the factor of safety $(F)$ value on slope instability if not controlled properly. For high water content sludge material disposed of in a tip, an example of the severe problems caused by failure of the impoundment bund is the flow slide for the $25 \mathrm{~m}$ high sewage sludge tip at Deighton (Yorkshire, UK) in 1992, where failure of the soil/ash bund allowed $250000 \mathrm{~m}^{3}$ of sewage sludge material to travel $200 \mathrm{~m}$ in a few minutes, engulfing an adjacent sewage works and blocking a $30 \mathrm{~m}$ wide river (Claydon et al., 1997). Improper placement of these materials in sanitary landfills or dedicated monofills may lead to problems such as, desiccation cracking and excessive differential settlements that may damage the landfill capping layer, generation of copious amounts of biogas by biosolids/sewage sludge materials and odour emission because of gas leakage from containment regions. Where biogas cannot escape, pore fluid pressures accumulate and cause heave of the landfill cover layer until a pathway develops for gas release. Localised differential settlement of the cover layer encourages surface water to infiltrate into the landfill body, potentially increasing the pore water pressure and piezometric head in the waste mass, which would have the effect of reducing the $F$ value on slope instability even further.

One of the most important geotechnical parameters governing the economics of successful land remediation and landfill or monofill operations is shear strength, which governs the slope gradients possible, as well as the construction methods that can be employed. Other parameters, such as compression, consolidation and permeability are also important in that the compression and consolidation affect the water content and void ratio and, hence, the strength and stability of the landfill body. Pertinent guidelines (e.g. EC, 1999, 2006) preclude sanitary landfill operators from accepting sludge materials having gravimetric water contents greater than $300 \%$ (solid content SC: $<25 \%$; ratio of the dry mass to the bulk sludge mass, as percentage), set as an indirect guide to the minimum shear strength required for efficient handling, placement of the material in a landfill and its geotechnical stability. However, in practice, the $300 \%$ maximum water content requirement is generally not a reliable guide for achieving minimum shear strengths necessary for landfilling. For instance, O'Kelly and Quille (2010) reviewed undrained strength against water content data presented for different alum WTR materials by Novak and Calkins (1975), Wang et al. (1992), Wichmann and Riehl (1997) and O'Kelly (2008a). They found that the undrained strength of these materials ranged $6-80 \mathrm{kPa}$ at $300 \%$ water content. Hence, as is widely acknowledged, the geotechnical criterion used in assessing waste materials for landfilling and other utilisation or disposal operations must be based on strength requirements (i.e. minimum undrained shear strength) (EA, 2010; O'Kelly, 2004, 2005b, 2010, 2016d; O'Kelly and Quille, 2010; Wichmann and Riehl, 1997). 


\section{Aims and objectives of this paper}

This paper presents a comprehensive review of reported field and laboratory investigations and theoretical work concerning the geotechnical behaviour/properties of biosolids, sewage sludge and WTR materials, specifically their physical, geotechnical index, compaction, undrained strength and effective stress strength properties, including effects of ongoing biodegradation. For WTR materials, this paper focuses on alum-generated residues (which constitute the bulk of such materials produced in the industry), but also describes the behaviour/properties expected for alum-lime, iron and polymer-generated WTRs. For details on the geotechnical behaviour of lime-softening sludge, the reader is referred to Raghu and Hsieh (1986), Ramer and Wang (2000), Wu et al. (2007) and Fei et al. (2016). This paper also presents characteristic compressibility, consolidation and permeability behaviour/properties of dewatered biosolids, sewage sludge and alum WTR materials. All these data are pertinent to the codisposal route at sanitary landfills, but for this case, the effects of other important factors such as mode of placement (layer thickness, processes of mixing and scarifying after placement etc.) must also be considered for the composite waste. Armed with an understanding of the geotechnical behaviour/properties of these challenging geomaterials, the paper then focuses on various geotechnical issues pertinent to landfill (monofill) disposal, including strength requirements, on-site and laboratory strength measurements, design strength and strength predictions by way of correlations with measured water content.

\section{Physical, geotechnical index and compaction properties}

Variability of municipal sludge and residue materials Selected geotechnical properties of biosolids, sewage sludge and WTR materials produced from various treatment plants around the world are listed in Table 1. A review of recent literature on the behaviour/properties of these materials with additives for solidification/stabilisation purposes has been presented by O'Kelly (2016c). The mineralogical and organic matter compositions of these materials are determined by the source of the water/ wastewater from which they were derived, types and extents of treatment processes employed, amounts of ions, suspended solids and colloidal materials removed and the types of chemicals added for the treatment and dewatering processes. For instance, the three most abundant compounds in alum WTR material are $>30 \mathrm{wt} \%$ silica, 10-56 wt $\%$ aluminium oxide and approximately $5 \mathrm{wt} \%$ iron (III) oxide (Babatunde and Zhao, 2007; Ippolito et al., 2011; Komlos et al., 2013; Watanabe et al., 2011), whereas for iron WTR material, the three most abundant compounds present are $>30 \mathrm{wt} \%$ iron (III) oxide, $10-20 \mathrm{wt} \%$ aluminium oxide and a varying amount of silica (Babatunde and Zhao, 2007; Ippolito et al., 2011). These differences in mineralogy and chemical compositions greatly influence the physical and geotechnical characteristics of the material produced. Hence, the characteristics of biosolids, sewage sludge and WTR materials vary from one treatment plant to another, and even for a specific plant from time to time, because of natural variations in the composition of the raw water/wastewater (Arulrajah et al., 2011; O'Kelly, 2006). For instance, in investigating links with geology/mineralogy for three distinct water sources, O'Kelly and Quille (2010) found that alum WTR materials derived from two separate peaty catchments (i.e. upland catchment of saturated peat over granite bedrock and lowland catchment of raised and riverine bogs over karstified limestone) had marginally lower plasticity and higher undrained strength for a given water content compared with WTR material derived from an upland catchment of limestone bedrock. Another influencing factor is the age of material deposited in stockpiles, pits, lagoons, landfills or monofills (determines amounts of drying, consolidation and/or biodegradation that have occurred post-treatment).

\section{Water content determinations}

For water content determinations on organic soils, charring, oxidation and (/or) vaporisation of susceptible organic matter may occur for the standard oven-drying temperature ranges of $110 \pm$ $5^{\circ} \mathrm{C}$ (ASTM, 2014) and $105-110^{\circ} \mathrm{C}$ (BSI, 1990a) specified for testing of inorganic soils. This would have the effect of producing apparent higher water content values. Some workers have adopted lower oven-drying temperatures in the range $50-90^{\circ} \mathrm{C}$ (e.g. $50^{\circ} \mathrm{C}$ (Arulrajah et al., 2011, 2013; Maghoolpilehrood et al., 2014, 2015; Suthagaran et al., 2009) and $60^{\circ} \mathrm{C}$ (Zhan et al., 2014)) for testing of biosolids and sewage sludge in an attempt to mitigate against this potential error, although all the relevant water is not fully evaporated from the oven-dried material at temperatures $<100^{\circ} \mathrm{C}$, which counteracts the intended purpose (i.e. an apparent lower water content value may be deduced instead). For instance, O'Kelly (2005c) showed that the mass of residual pore water in a test specimen of sewage sludge material oven dried at $60^{\circ} \mathrm{C}$ was greater than the mass loss due to any charring, oxidation and/or vaporisation of susceptible organic matter at $105^{\circ} \mathrm{C}$. Further, some WTR materials can have unusual oven-drying behaviour - for example, the mass of alum WTR test specimens investigated by O'Kelly (2014b) showed no signs of equilibrating after a 34-d drying period at $105^{\circ} \mathrm{C}$. From oven-drying tests on various biosolids, sewage sludge, WTR and other highly organic soil materials, O'Kelly (2014b) and O'Kelly and Sivakumar (2014) demonstrated that oven drying at $105-110^{\circ} \mathrm{C}$ is acceptable for routine water content determinations and is also preferable (for the reason cited above) over oven-drying temperatures of $\leq 80^{\circ} \mathrm{C}$. This is consistent with US EPA (2001) and ASTM (2014) standard test methods and also with the findings of Skempton and Petley (1970) and Hobbs (1986) for water content determinations on peats and other organic soils.

\section{Soil description}

\section{Particle size distribution}

Various challenges in performing wet sieving, sedimentation and laser diffraction analysis testing for the determination of the particle size distribution of biosolids and sewage sludge materials have been discussed by Kayser (2012) and O'Kelly (2016a). With 


\begin{tabular}{|c|c|c|c|c|c|c|c|c|c|}
\hline Material & $\begin{array}{l}\text { Liquid } \\
\text { limit: \% }\end{array}$ & $\begin{array}{l}\text { Plastic } \\
\text { limit: \% }\end{array}$ & $\begin{array}{l}\text { Plasticity } \\
\text { index: \% }\end{array}$ & $\begin{array}{l}\text { Specific } \\
\text { gravity }\end{array}$ & TVS: \% & $\mathrm{pH}$ & $\begin{array}{l}\text { Silt- and } \\
\text { clay-sized } \\
\text { particles: } \\
\text { wt } \%\end{array}$ & $\begin{array}{c}\text { Rate } \\
\text { dependence } \\
\text { parameter, } \\
\mu^{\mathrm{b}}\end{array}$ & $\begin{array}{c}\text { Soil } \\
\text { classification }^{\text {b }} \\
\text { (BSI, 2015) }\end{array}$ \\
\hline $\begin{array}{l}\text { Sewage sludge } 1 \\
\text { (O'Kelly 2006, 2008b, } \\
\text { 2013a, 2013c) }\end{array}$ & 315 & 55 & 260 & $1 \cdot 55$ & 70 & $8 \cdot 0$ & - & - & $\begin{array}{l}\text { Organic clay of } \\
\text { extremely } \\
\text { high plasticity }\end{array}$ \\
\hline $\begin{array}{l}\text { Sewage sludge } 2 \\
\text { (Chen et al., 2014) }\end{array}$ & 115 & 75 & 40 & $2 \cdot 05$ & $61-70$ & - & 48 & - & $\begin{array}{l}\text { Organic silt of } \\
\text { extremely } \\
\text { high plasticity }\end{array}$ \\
\hline $\begin{array}{l}\text { Sewage sludge } 3 \\
\text { (Diliūnas et al., 2010) }\end{array}$ & 352 & 215 & 137 & $1 \cdot 69$ & $57 \cdot 0$ & $7-8$ & - & - & $\begin{array}{l}\text { Organic silt of } \\
\text { extremely } \\
\text { high plasticity }\end{array}$ \\
\hline $\begin{array}{l}\text { Sewage sludge } 4 \\
\text { (Lin et al., 2013) }\end{array}$ & - & - & 256 & 1.61 & $43 \cdot 0$ & - & - & - & - \\
\hline $\begin{array}{l}\text { Sewage sludge } 5 \\
\text { (Zhan et al., 2014) }\end{array}$ & 353 & 106 & 247 & $1 \cdot 73-1.95$ & $32 \cdot 3-51 \cdot 0$ & - & 75 & - & $\begin{array}{l}\text { Organic clay of } \\
\text { extremely } \\
\text { high plasticity }\end{array}$ \\
\hline $\begin{array}{l}\text { Sewage sludges 6a-6e } \\
\text { (from drying beds) } \\
\text { (Stone et al., 1998) }\end{array}$ & $66-165^{a}$ & $57-117^{a}$ & $0-48^{a}$ & $0.93-2.04$ & $14 \cdot 3-67 \cdot 2$ & - & $0 \cdot 5-3 \cdot 5$ & - & $\begin{array}{l}\text { Organic silt of } \\
\text { high to } \\
\text { extremely } \\
\text { high plasticity }\end{array}$ \\
\hline $\begin{array}{l}\text { Sewage sludge } 7 \\
\text { (He et al., 2015) }\end{array}$ & $515 \cdot 1$ & $94 \cdot 8$ & $420 \cdot 3$ & $1 \cdot 61$ & - & - & - & - & $\begin{array}{l}\text { Organic clay of } \\
\text { extremely } \\
\text { high plasticity }\end{array}$ \\
\hline Biosolids $1^{d}$ & 458 & 68 & 390 & 1.68 & 63 & $7 \cdot 8$ & 78 & $\begin{array}{c}0.39 \\
(w=100 \%)\end{array}$ & $\begin{array}{l}\text { Organic clay of } \\
\text { extremely } \\
\text { high plasticity }\end{array}$ \\
\hline $\begin{array}{l}\text { Biosolids } 2 \\
\text { (Kayser et al., 2011) }\end{array}$ & 666 & 105 & 561 & $1 \cdot 62$ & $66-70$ & $8 \cdot 3$ & $>92 \cdot 1$ & $\begin{array}{c}0.38 \\
(w=355 \%)\end{array}$ & $\begin{array}{l}\text { Organic clay of } \\
\text { extremely } \\
\text { high plasticity }\end{array}$ \\
\hline $\begin{array}{l}\text { Biosolids } 2(w=355 \%) \\
\text { amended with } \\
20 \% \text { lime } \\
\text { (Kayser et al., 2011) }\end{array}$ & - & - & - & - & $50-55$ & $12 \cdot 4$ & - & $0 \cdot 34$ & - \\
\hline $\begin{array}{l}\text { Biosolids } 3 \text { (air-dried) } \\
\text { (Kim et al., 2005) }\end{array}$ & 99 & 49 & 50 & $1 \cdot 56$ & $38-41$ & $7 \cdot 9-8 \cdot 1$ & - & - & $\begin{array}{l}\text { Organic silt of } \\
\text { extremely } \\
\text { high plasticity }\end{array}$ \\
\hline $\begin{array}{l}\text { Biosolids } 4 \text { (GLSEC, } \\
\text { 2003) }\end{array}$ & $71-119^{a}$ & $54-85^{a}$ & $17-53^{a}$ & $1 \cdot 81-2 \cdot 17$ & $32-34$ & - & $40-50$ & - & $\begin{array}{l}\text { Organic silt of } \\
\text { high to } \\
\text { extremely } \\
\text { high plasticity }\end{array}$ \\
\hline $\begin{array}{l}\text { Aged biosolids } 1 \\
\text { (stockpiled) (Arulrajah } \\
\text { et al., 2011, 2013) }\end{array}$ & $100-110^{a}$ & $79-83^{a}$ & $21-27^{a}$ & $1 \cdot 86-1 \cdot 88$ & $35 \cdot 4-38 \cdot 5$ & $4 \cdot 67$ & $37-50$ & - & $\begin{array}{l}\text { Organic silt of } \\
\text { extremely } \\
\text { high plasticity }\end{array}$ \\
\hline
\end{tabular}

\footnotetext{
${ }^{a}$ Measured for air-dry material

${ }^{\mathrm{b}}$ Deduced in present investigation

c Reported as possessing slight to little plasticity

d From forthcoming article entitled 'Shear strength of biosolids for monofill design' by Oettle, O'Kelly and Ramos
}

Table 1. Selected geotechnical properties of various biosolids, sewage sludge and WTR materials (continued on next two pages) 


\begin{tabular}{|c|c|c|c|c|c|c|c|c|c|}
\hline Material & $\begin{array}{l}\text { Liquid } \\
\text { limit: \% }\end{array}$ & $\begin{array}{l}\text { Plastic } \\
\text { limit: \% }\end{array}$ & $\begin{array}{l}\text { Plasticity } \\
\text { index: \% }\end{array}$ & $\begin{array}{l}\text { Specific } \\
\text { gravity }\end{array}$ & TVS: \% & $\mathrm{pH}$ & $\begin{array}{l}\text { Silt- and } \\
\text { clay-sized } \\
\text { particles: } \\
\text { wt\% }\end{array}$ & $\begin{array}{c}\text { Rate } \\
\text { dependence } \\
\text { parameter, } \\
\mu^{\mathrm{b}}\end{array}$ & $\begin{array}{c}\text { Soil } \\
\text { classification }^{\mathrm{b}} \\
(\mathrm{BSI}, 2015)\end{array}$ \\
\hline $\begin{array}{l}\text { Aged biosolids } 2 \\
\text { (stockpiled) } \\
\text { (Wanigaratne and } \\
\text { Udamulla, 2012) }\end{array}$ & $79 \cdot 8^{a}$ & $\begin{array}{l}\text { Non- } \\
\text { plastic }^{a}\end{array}$ & $0^{a}$ & 1.93 & $25 \cdot 5$ & - & - & - & $\begin{array}{l}\text { Organic silt } \\
\text { (non plastic) }\end{array}$ \\
\hline $\begin{array}{l}\text { Aged biosolids } 3 \\
\text { (air-dried in stockpile) } \\
\text { (Maghoolpilehrood } \\
\text { et al., 2013) }\end{array}$ & 100 & 80 & 20 & $1 \cdot 77$ & 27 & - & - & - & $\begin{array}{l}\text { Organic silt of } \\
\text { extremely } \\
\text { high plasticity }\end{array}$ \\
\hline $\begin{array}{l}\text { Aged biosolids } 4 \\
\text { (air-dried in stockpile) } \\
\text { (Maghoolpilehrood } \\
\text { et al., 2014, 2015) }\end{array}$ & $61 \cdot 5^{a}$ & $25 \cdot 1^{a}$ & $36 \cdot 4^{a}$ & $2 \cdot 58$ & $9 \cdot 9-10 \cdot 4$ & $7 \cdot 38$ & 40 & - & $\begin{array}{r}\text { Organic clay of } \\
\text { high plasticity }\end{array}$ \\
\hline $\begin{array}{l}\text { Aged biosolids } 5 \\
\text { (stockpiled, >12 } \\
\text { years) (Ukwatta et al., } \\
\text { 2015) }\end{array}$ & $46-67^{a}$ & $21-41^{a}$ & $25-33^{a}$ & $2 \cdot 43-2 \cdot 52$ & $6 \cdot 3-14 \cdot 4$ & - & $10-18$ & - & $\begin{array}{l}\text { Organic clay of } \\
\text { intermediate } \\
\text { to high } \\
\text { plasticity }\end{array}$ \\
\hline $\begin{array}{l}\text { Aged biosolids } 6 \\
\text { (stockpiled) } \\
\text { (Ukwatta et al., 2016) }\end{array}$ & $53^{a}$ & $27^{a}$ & $26^{a}$ & $2 \cdot 51$ & $7 \cdot 1$ & - & 10 & - & $\begin{array}{r}\text { Organic clay of } \\
\text { high plasticity }\end{array}$ \\
\hline $\begin{array}{l}\text { Alum WTR } 1 \\
\text { (O'Kelly, 2008a) }\end{array}$ & 490 & 240 & 250 & $1 \cdot 86$ & 57 & $8 \cdot 6$ & - & - & $\begin{array}{l}\text { Organic silt of } \\
\text { extremely } \\
\text { high plasticity }\end{array}$ \\
\hline $\begin{array}{l}\text { Alum WTR } 2 \\
\text { (O'Kelly, 2010) }\end{array}$ & 550 & 260 & 290 & 1.99 & 45 & $7 \cdot 1$ & - & - & $\begin{array}{l}\text { Organic silt of } \\
\text { extremely } \\
\text { high plasticity }\end{array}$ \\
\hline $\begin{array}{l}\text { Alum WTR } 3 \\
\text { (O'Kelly, 2010) }\end{array}$ & 430 & 220 & 210 & 1.90 & 46 & $7 \cdot 2$ & - & - & $\begin{array}{l}\text { Organic silt of } \\
\text { extremely } \\
\text { high plasticity }\end{array}$ \\
\hline $\begin{array}{l}\text { Alum WTR } 4 \\
\text { (O'Kelly, 2014a, } \\
\text { 2014b, 2016c) }\end{array}$ & 513 & 268 & 245 & $1 \cdot 86$ & 57 & $8 \cdot 6$ & - & $\begin{array}{c}0.20 \\
(w=222 \%)\end{array}$ & $\begin{array}{l}\text { Organic silt of } \\
\text { extremely } \\
\text { high plasticity }\end{array}$ \\
\hline $\begin{array}{l}\text { Alum WTR } 5 \text { (Wang } \\
\text { et al., 1992; Wang } \\
\text { and Tseng, 1993) }\end{array}$ & 550 & 239 & 311 & $2 \cdot 26$ & - & - & - & - & $\begin{array}{l}\text { Organic silt of } \\
\text { extremely } \\
\text { high plasticity }\end{array}$ \\
\hline $\begin{array}{l}\text { Alum WTR } 6 \\
\text { (Wang et al., 1992) }\end{array}$ & 423 & 137 & 286 & $2 \cdot 33$ & - & - & - & - & $\begin{array}{l}\text { Organic silt of } \\
\text { extremely } \\
\text { high plasticity }\end{array}$ \\
\hline $\begin{array}{l}\text { Alum WTR } 7 \\
\text { (Basim, 1999) }\end{array}$ & 371 & 228 & 143 & $1 \cdot 88$ & 38 & - & 81 & - & $\begin{array}{l}\text { Organic silt of } \\
\text { extremely } \\
\text { high plasticity }\end{array}$ \\
\hline $\begin{array}{l}\text { Alum WTR } 8 \\
\text { (Basim, 1999) }\end{array}$ & 206 & 115 & 91 & $2 \cdot 00$ & 30 & - & 69 & - & $\begin{array}{l}\text { Organic silt of } \\
\text { extremely } \\
\text { high plasticity }\end{array}$ \\
\hline
\end{tabular}




\begin{tabular}{|c|c|c|c|c|c|c|c|c|c|}
\hline Material & $\begin{array}{l}\text { Liquid } \\
\text { limit: \% }\end{array}$ & $\begin{array}{l}\text { Plastic } \\
\text { limit: \% }\end{array}$ & $\begin{array}{l}\text { Plasticity } \\
\text { index: \% }\end{array}$ & $\begin{array}{l}\text { Specific } \\
\text { gravity }\end{array}$ & TVS: \% & $\mathrm{pH}$ & $\begin{array}{c}\text { Silt- and } \\
\text { clay-sized } \\
\text { particles: } \\
\text { wt\% }\end{array}$ & $\begin{array}{c}\text { Rate } \\
\text { dependence } \\
\text { parameter, } \\
\mu^{b}\end{array}$ & $\begin{array}{c}\text { Soil } \\
\text { classification }^{\mathrm{b}} \\
(\mathrm{BSI}, 2015)\end{array}$ \\
\hline $\begin{array}{l}\text { Alum WTR } 9 \text { (Roque } \\
\text { and Carvalho, 2006) }\end{array}$ & $107 \cdot 5$ & $81 \cdot 7$ & $25 \cdot 8$ & $2 \cdot 27$ & 10 & - & 86 & - & $\begin{array}{l}\text { Organic silt of } \\
\text { extremely } \\
\text { high plasticity }\end{array}$ \\
\hline $\begin{array}{l}\text { Alum and lime WTR } 1 \\
\text { (Basim, 1999) }\end{array}$ & 329 & 200 & 129 & $2 \cdot 38$ & 30 & - & 98 & - & $\begin{array}{l}\text { Organic silt of } \\
\text { extremely } \\
\text { high plasticity }\end{array}$ \\
\hline $\begin{array}{l}\text { Alum and lime WTR } 2 \\
\text { (Raghu and Hsieh, } \\
\text { 1986) }\end{array}$ & - & - & c & 1.90 & $33 \cdot 5$ & - & 84 & - & - \\
\hline $\begin{array}{l}\text { Alum and polymer } \\
\text { WTR } 1 \text { (Basim, 1999) }\end{array}$ & 690 & 20 & 670 & $2 \cdot 12$ & 38 & - & 56 & - & $\begin{array}{l}\text { Organic clay of } \\
\text { extremely } \\
\text { high plasticity }\end{array}$ \\
\hline $\begin{array}{r}\text { Polymer WTR } 1 \\
\text { (Basim, 1999) }\end{array}$ & 161 & 57 & 104 & $2 \cdot 26$ & 31 & - & 71 & - & $\begin{array}{l}\text { Organic clay of } \\
\text { extremely } \\
\text { high plasticity }\end{array}$ \\
\hline $\begin{array}{l}\text { Iron WTR } 1 \\
\text { (Wang et al., 1992) }\end{array}$ & 108 & 47 & 61 & $2 \cdot 72$ & - & - & - & - & $\begin{array}{l}\text { Organic silt of } \\
\text { extremely } \\
\text { high plasticity }\end{array}$ \\
\hline $\begin{array}{l}\text { Lime-softening } \\
\text { sludge } 1 \text { (Raghu } \\
\text { and Hsieh, 1986) }\end{array}$ & 38 & 31 & 7 & $2 \cdot 65$ & $9 \cdot 3$ & - & 51 & - & $\begin{array}{l}\text { Silt of } \\
\text { intermediate } \\
\text { plasticity }\end{array}$ \\
\hline $\begin{array}{l}\text { Lime-softening sludge } 2 \\
\text { (Fei et al., 2016) }\end{array}$ & 38 & 32 & 6 & $2 \cdot 57$ & - & 11 & 83 & - & $\begin{array}{l}\text { Silt of } \\
\text { intermediate } \\
\text { plasticity }\end{array}$ \\
\hline
\end{tabular}

Table 1. Continued

these materials comprised of flocs of clay-/silt-sized particles having high organic matter content, the question inevitably arises as to what constitutes an individual particle for the purposes of determining the grading curve for the test material. Nevertheless, referring to the grading curves in Figures 1(a) and 1(b), the solid particles in biosolids, sewage sludge and WTR materials are predominantly fine-grained $(<0.06 \mathrm{~mm}$ in nominal size $)$, with a significant proportion within the clay size range $(<2 \mu \mathrm{m})$. Referring to Figure 1(c), the grading curves reported for air-dry sewage sludge material and biosolids/sewage sludge materials sourced from drying beds and stockpiles of aged material can suggest that these are sandy silt (Arulrajah et al., 2013; GLSEC, 2003) or very gravelly sand (Stone et al., 1998) materials, but this misclassification can be explained by insufficient disaggregation of the soil clumps in preparing the test materials for particle size distribution analysis. When the appropriate levels of disaggregation are achieved in preparing the test material, grading curves for such materials more closely resemble those of the wet materials - for example, see grading curve for aged biosolids 4 in Figure 1(a). Referring to Figure 1(b), the grading of the different WTR materials presented appears related to the coagulant type, with lime softening, alum-polymer, alum and alum-lime treatments generally producing successively finer residue materials.

\section{Organic matter content}

The organic matter content of biosolids, sewage sludge and WTR materials is usually evaluated indirectly as total volatile solids (TVS) by using ignition loss tests. TVS values typically range from 40 to $70 \%$ for young biosolids and sewage sludge materials and $6 \%$ (>12 years) to $40 \%$ for aged biosolids, with the very high organic matter content mainly explaining the extremely high water content and plasticity exhibited by these materials. For aged biosolids 1, Arulrajah et al. (2011) reported a TVS of $\sim 27 \%$ and total organic carbon of $17 \cdot 4 \%$ (with standard deviation of $2 \cdot 3 \%$ ), indicating a conversion factor relating TVS to total organic carbon for this particular material of $\sim 1 \cdot 55$. Traditionally, for natural soils, a conversion factor of 1.724 is used, on the assumption that organic matter contains an average of $58 \%$ organic carbon (Nelson and Sommers, 1996), although there is no universal conversion factor value, with it varying from soil to soil and also depending on the type of organic matter present. 
Geotechnical Research

Volume 3 Issue 4
Geotechnics of municipal sludges and

residues for landfilling

O'Kelly

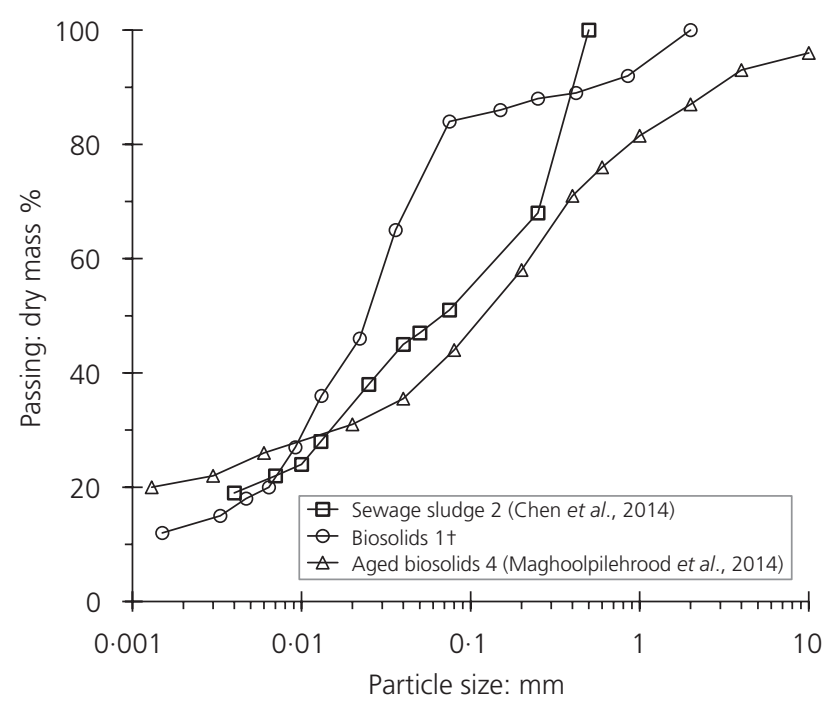

(a)

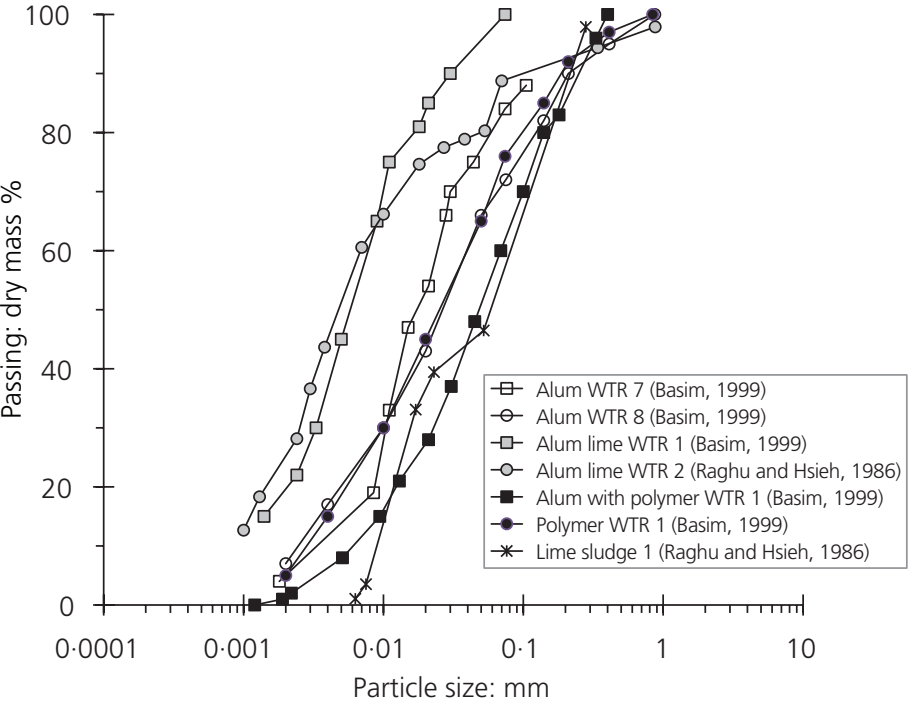

(b)

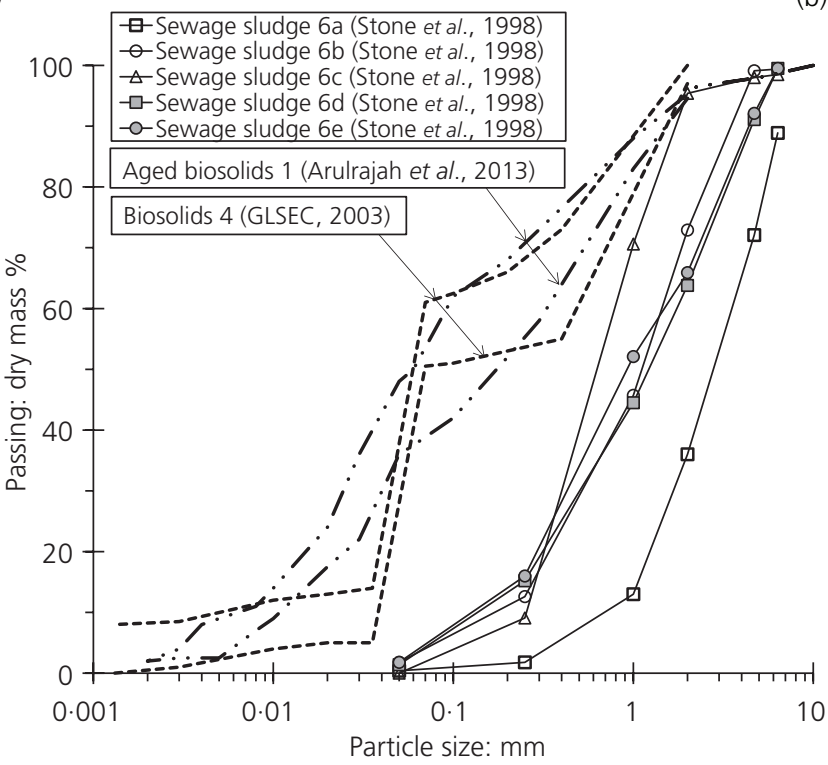

(c)

Figure 1. Particle size distribution curves: (a) wet biosolids and sewage sludge, (b) WTRs produced for various chemical treatments, (c) air-dried and stockpiled biosolids and sewage sludge materials (†from forthcoming article entitled 'Shear strength of biosolids for monofill design' by Oettle, O'Kelly and Ramos)
Compared with biosolids and sewage sludge materials, the organic matter content of WTR materials is generally significantly lower. The high reported TVS values of 30-57\% (alum WTRs 1-4, 7 and 8), 30 and 33.5\% (alum-lime WTRs 1 and 2) and $35 \%$ (alum and polymer WTR 1) significantly overestimate the organic matter content of these WTR materials. This is largely explained by the alum present (which typically comprises 5-15 $\mathrm{wt} \%$ of alum WTR material (Wang et al., 1992)) losing significant amounts of structural water or hydroxyl groups at the furnace temperature of $440^{\circ} \mathrm{C}$ used to ignite the test specimens. More reliable measurements of the organic matter content for WTR materials are usually obtained using Walkley and Black's method (see BSI (1990b)), which employs dichromate oxidation, or by correlating TVS with organic content using total organic carbon measurements.

\section{Classification: biosolids and sewage sludge materials}

From Table 1, compared with typical inorganic clayey soils, biosolids and sewage sludge materials generally have extremely high values of liquid limit $(L L)$, plastic limit $(P L)$ and plasticity index $(P I=L L-$ $P L)$. On the extended plasticity chart, dewatered biosolids and sewage sludge materials invariably plot above the A-line and are classified as organic clay of extremely high plasticity (Figure 2). However, air-dry sewage sludge test material (GLSEC, 2003; Kim et al., 2005) or biosolids and sewage sludge materials sampled from drying beds (Stone et al., 1998) and stockpiles (Arulrajah et al., 


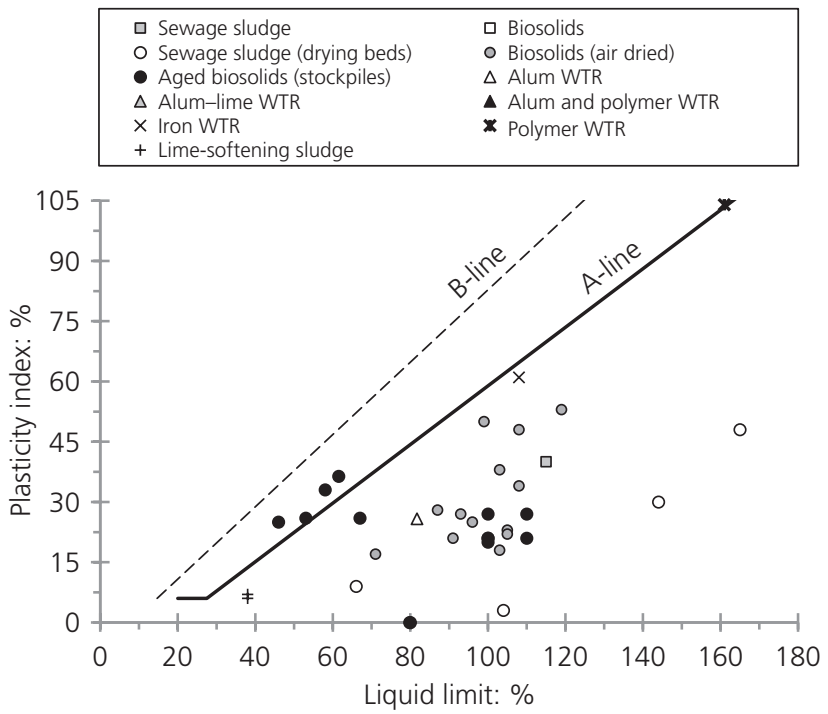

(a)

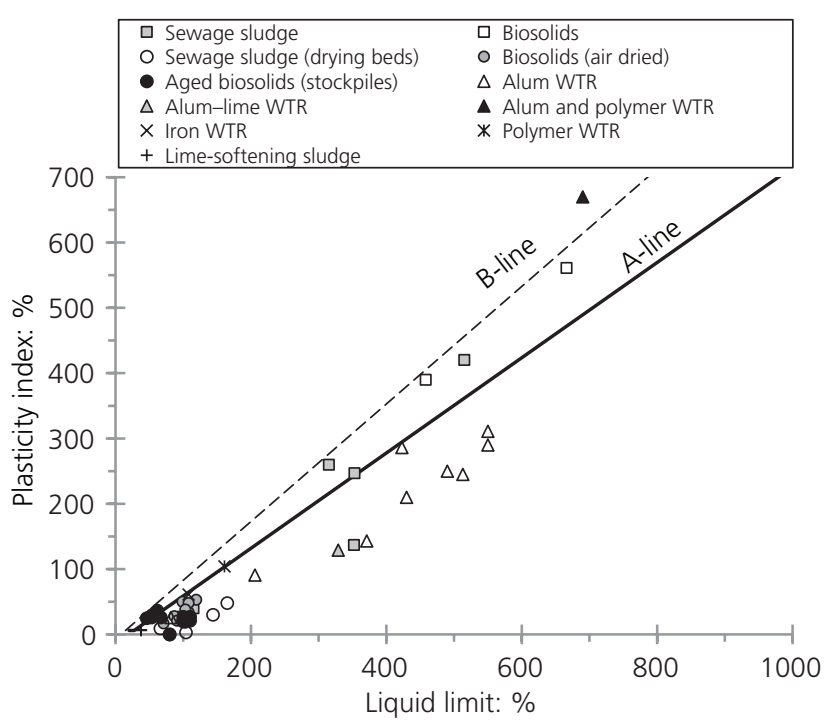

(b)

Figure 2. Soil classification: (a) plasticity chart and (b) extended plasticity chart

2011; Maghoolpilehrood et al., 2013; Wanigaratne and Udamulla, 2012) plot below the A-line and are classified as organic silt of high to extremely high plasticity. Exceptions include aged biosolids 2, which were reported as non-plastic (Wanigaratne and Udamulla, 2012), and aged biosolids 4-6 materials, which are classified in the present investigation as organic clay of intermediate to high plasticity. As described by O'Kelly (2016a), during the drying process, the soil structure alters significantly, with the solid 'particles'/aggregates clumping together forming peds, in addition to permanent material changes caused by oxidation and biodegradation processes, which have the effect of substantially reducing the plasticity. Similar transformational behaviour has been reported to accompany the drying (oxidation) of peat materials (O'Kelly and Pichan, 2013).

\section{WTR materials}

All the WTR materials considered in the present investigation plot below the A-Line on the plasticity chart, apart from the alum and polymer WTR 1 and the polymer WTR 1 materials. Alum, alum-lime and iron WTRs are classified as organic silt of extremely high plasticity. Compared with iron WTR, the presence of hydrated calcium aluminates and hydrated aluminium sulfate explain the high capacity of water retention and significantly greater plasticity of the alum WTRs. According to O'Kelly (2008a), significant irreversible decreases in plasticity occur for the drying of alum WTR material, characteristic of some soils rich in oxides and hydroxides of aluminium (Mitchell and Soga, 2005). Lime-softening sludge, typically comprising 80-95 wt $\%$ calcite (Raghu and Hsieh, 1986), is classified as silt of low to intermediate plasticity. The alum and polymer WTR 1 and the polymer WTR 1 are classified as organic clay of extremely high plasticity, and it is postulated that this change in material characteristics, from that of silt to clay, was due to the polymer additive. The alum and polymer WTR 1 materials plots above the B-line (a tentative upper limit set for all natural soils drawn from experimental data), consistent with its unconventional composition for soil.

\section{Specific gravity of solids}

Compared with inorganic clayey soils (typical $G_{\mathrm{S}}$ of $2 \cdot 5-2 \cdot 75$ ), the biosolids, sewage sludge and WTR materials typically have low specific gravity of solids (refer to Table 1) and, hence, low bulk and dry density values. The ongoing biodegradation of biosolids and sewage sludge reduces the solids mass (volume) due to loss of susceptible organic matter, as reflected by the reduction in TVS and increase in specific gravity (Diliūnas et al., 2010; O'Kelly, 2005a, 2006, 2008b; Zhan et al., 2014). For instance, sewage sludge 1 slurry material was stored outdoors in drums and allowed to biodegrade naturally for a 13-year period at ambient temperatures of $5-15^{\circ} \mathrm{C}$ (O'Kelly, 2006, 2008b). Further, the same slurry material was biodegraded for a $21-\mathrm{d}$ period at the optimum temperature for mesophilic digestion of $35^{\circ} \mathrm{C}$, which produced a $33 \%$ reduction in its solids dry mass, with the TVS value reducing from 70 to $55 \%$ (O'Kelly, 2005a, 2006). These two test conditions are represented by data points A-F in Figure 3(a). The increase in specific gravity occurs due to loss of biodegradable components having low $G_{\mathrm{S}}$. In practice, if this increase in $G_{\mathrm{S}}$ is not considered in mass-volume relation calculations for biosolids and sewage sludge, the knock-on effect is an overestimation of the degree of saturation and underestimation of the gas content for these materials (O'Kelly, 2013a, 2016c). Similar conclusions were reported by Yesiller et al. (2014) for MSW material. In this regard, O'Kelly (2016c) presented a new correlation for specific gravity determinations from measured TVS values for biosolids and sewage sludge materials, with the specific gravity of the inorganic and organic fractions determined as 


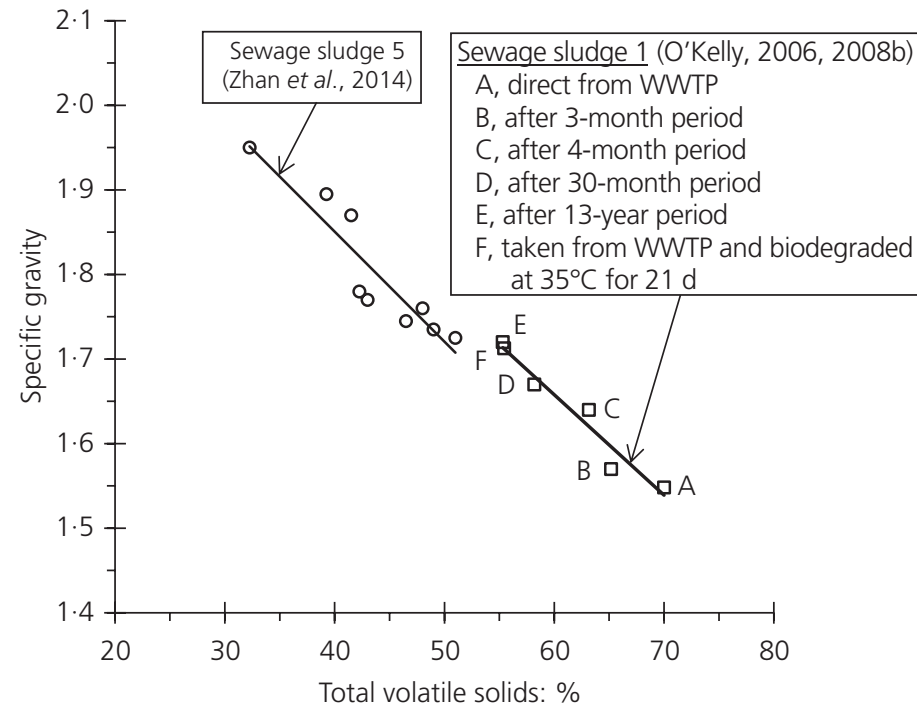

(a)

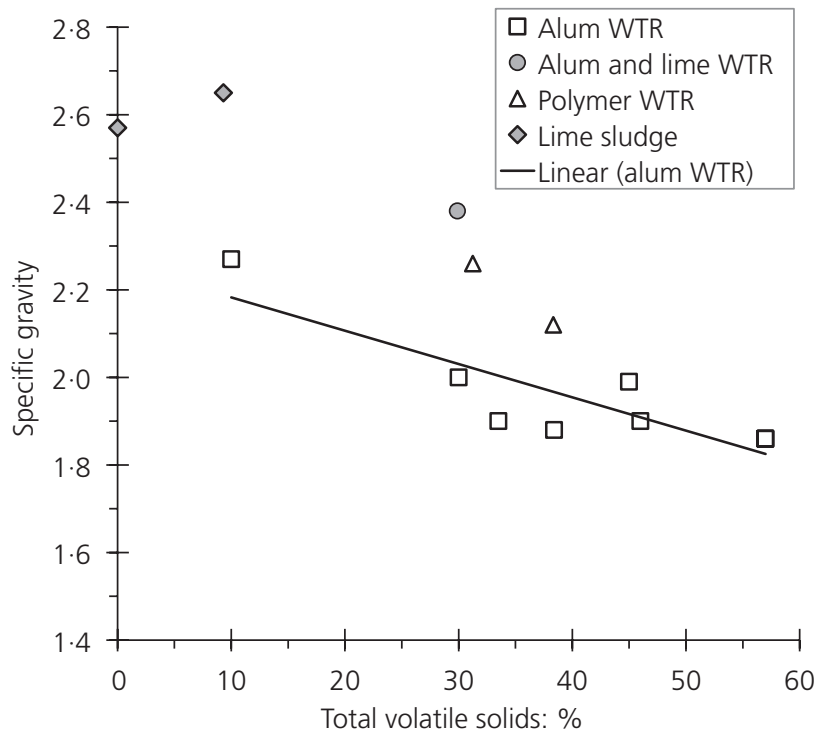

(b)

Figure 3. Specific gravity against total volatile solids: (a) sewage sludge and (b) WTR and lime sludge materials

$2 \cdot 65$ and $1 \cdot 32$, respectively. These values are dissimilar from corresponding values reported for peat, organic clay (Hobbs, 1986; Skempton and Petley, 1970) and paper mill sludge (Moo-Young and Zimmie, 1996) materials on account of inherent differences in mineralogy and the nature (origin) of the organic matter, which for biosolids and sewage sludge materials principally comprises proteins, carbohydrates and oils and greases (Metcalf and Eddy, Inc., 2004).

For lime-softening sludge and WTR materials, mineralisation rates of organic carbon and nitrogen are very slow and similar to those of natural soils (Elliott et al., 1990). For instance, the measured TVS value of alum WTR 4 material remained unchanged at 57\% after this material had been stored at constant composition and ambient laboratory temperature for a 5-year period (O’Kelly, 2014a), indicating that its organic matter content had remained unchanged. For alum WTR material, the specific gravity would appear to be approximately inversely related to TVS (see correlation line in Figure 3(b)). Further, considering that the TVS significantly overestimates organic matter content for alum WTRs ('Organic matter content' section), the specific gravity of WTR materials is generally strongly dependent on the mass percentage and specific gravity of the chemical additives. From the limited data in Figure 3(b), it would appear that for a given TVS value, alum-lime WTR has a higher specific gravity than polymer WTR, which in turn has higher specific gravity than alum WTR. Lime-softening sludge has a low TVS $(<10 \%)$ and a specific gravity of typically 2.60 (consistent with its $80-95 \mathrm{wt} \%$ calcite content having a specific gravity of $2 \cdot 71$ ).

\section{Compaction}

Biosolids, sewage sludge and alum WTR materials compact poorly, producing relatively flat dry density against water content curves (Figure 4). In the author's experience, compaction testing of sewage sludge starting with the material prepared at the wet side of the optimum water content $(O W C)$ for compaction, and proceeding to the dry side of $O W C$, produces marginally higher compacted dry densities compared with the standard procedure of testing from the dry side to the wet side of $O W C$ (BS EN 13774:1990 (BSI, 1990c)). This difference in compaction behaviour can be explained by the difficulty in uniformly rewetting the dry sewage sludge (biosolids) peds. Similar findings were reported by Basim (1999) for WTR materials. For these reasons, the author recommends that compaction practice for biosolids, sewage sludge and WTR materials requires that compaction testing proceed from the wet side to dry side of the $O W C$.

Compared with inorganic clayey soils, these materials have significantly lower maximum dry density $\left(\rho_{\mathrm{d}_{\max }}\right)$, higher $O W C$ for compaction and higher air content values - for example, standard Proctor compaction of sewage sludge 1 material at its $O W C$ value of $85 \%$ produced a $\rho_{\mathrm{d}_{\max }}$ value of $0.56 \mathrm{t} / \mathrm{m}^{3}$ (Figure $4(\mathrm{a})$ ) and an air content of $16.3 \%$ (O'Kelly, 2016a). From the data presented by Arulrajah et al. (2011) for aged biosolids 1 material compacted using standard Proctor energy $\left(\rho_{\mathrm{d}_{\max }}=0.80-0.82 \mathrm{t} / \mathrm{m}^{3}\right)$, the author deduced an air content of $\sim 15 \%$ for the reported $O W C$ range of $51-53 \%$. This compares with approximately 5\% air content for standard Proctor compaction at the $O W C$ for inorganic clayey soils. The saturated bulk density and the dry density zero-air-voids curves plotted in Figures 4(a) and 4(b) relate to the fully saturated condition (e.g. achieved by mechanically pressing or on-site consolidation of these materials) and are computed from their respective specific gravity values.

Having similar plasticity characteristics, and with $G_{\mathrm{S}}$ ranging from 1.86 to 1.99 , the density-water content curves for alum WTR $1-3$ 
Geotechnics of municipal sludges and residues for landfilling O'Kelly

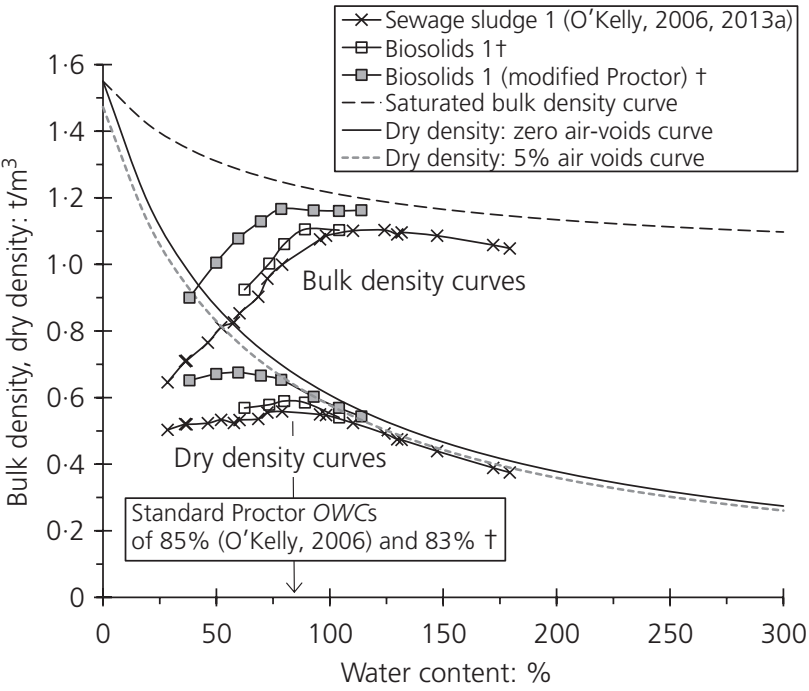

(a)

Figure 4. Density against water content curves (standard Proctor energy unless stated otherwise): (a) biosolids and sewage sludge; (b) alum WTRs. Note: zero air voids (saturation) curves in

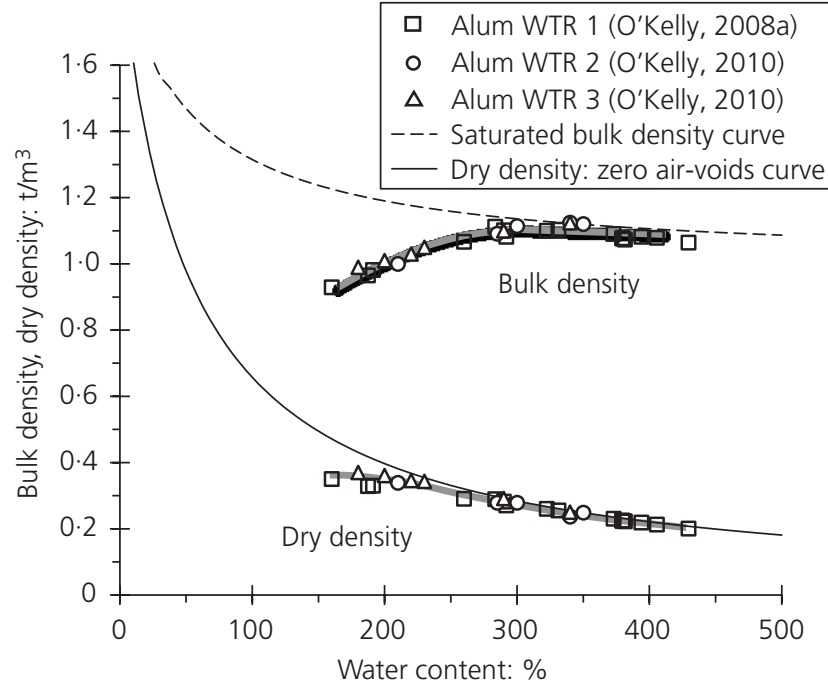

(b)

Figures $4(a)$ and $4(b)$ based on mean $G_{s}$ values of 1.55 and 1.92 , respectively (tfrom forthcoming article entitled 'Shear strength of biosolids for monofill design' by Oettle, O'Kelly and Ramos) materials plot along common trend lines (Figure 4(b)). Wang et al. (1992) reported that alum WTR 5 and 6 materials did not exhibit peak formation in their standard Proctor dry density-water content compaction curves. This also appears to be the case for alum WTR 1-3 materials over the water content range investigated (see Figure 4(b), in which the experimental dry density curve is relatively flat, ranging from 0.20 to $0.37 \mathrm{t} / \mathrm{m}^{3}$ for $w=160-430 \%$ ). For most inorganic soils, the $O W C$ for compaction is about $10 \%$ (in terms of the percentage of difference rather than the actual water content) less than the $P L$ (Sridharan and Nagaraj, 2005). On this basis, with $P L=220-260 \%$, the $O W C$ for compaction of alum WTRs 1-3 would occur at approximately $200 \%$ water content. In Figure 4(b), the dry density curve for these materials appears to be plateauing in the vicinity of $200 \%$ water content, supporting this analysis. For alum WTR 9 (Roque and Carvalho, 2006) and iron WTR 1 (Wang et al., 1992), the dry density-water content curves exhibit the typical one-hump shape, with reported $\rho_{\mathrm{d}_{\max }}$ of 0.63 and $1.13 \mathrm{t} / \mathrm{m}^{3}$, respectively, at $O W C$ for compaction values of 84 and $\sim 45 \%$, respectively. Compared with alum WTR, the significantly greater $\rho_{\mathrm{d}_{\max }}$ achieved for iron WTR is largely accounted for by its significantly higher $G_{\mathrm{S}}$ value.

In a forthcoming article entitled 'Shear strength of biosolids for monofill design' by Oettle, O'Kelly and Ramos, the authors investigated standard and modified (heavy) compaction behaviour/properties of the biosolids 1 material (see Figure 4(a)), and as expected, modified Proctor compaction produced a higher $\rho_{\mathrm{d}_{\max }}$ of $0.67 \mathrm{t} / \mathrm{m}^{3}$ and lower $O W C$ value of $59 \%$ compared with standard Proctor energy $\left(0.58 \mathrm{t} / \mathrm{m}^{3}\right.$ and $83 \%$, respectively). In practice, for low confinement stress conditions, inundation with water and compaction-induced overconsolidation state result in significant swelling and strength reduction for compacted biosolids and sewage sludge materials (O'Kelly, 2004, 2010; O'Kelly and Quille, 2010), such that the standard (rather than modified) Proctor compaction is more appropriate on-site (see also section titled 'Strength reduction due to compaction-induced overconsolidation').

As described by O'Kelly (2004, 2010), to maximise the operational life of the monofill site and for efficient handling, placement and compaction, the water content of the material should fall between the $O W C$ for compaction and the sticky/adhesion limit (water content value below which material does not adhere to smooth metal surface) - for example, water content ranges of 260-365\% and $220-345 \%$ for alum WTRs 2 and 3, respectively (O'Kelly, 2010 ) and $85-95 \%$ for sewage sludge 1 (O'Kelly, 2004). For water contents above the adhesion limit, the handling and landfilling operations prove more difficult due, in part, to the tendency of the materials to adhere to the machine plant.

\section{Biodegradation effects for physiochemical properties of biosolids and sewage sludge}

Greater levels of biodegradation for biosolids and sewage sludge materials are accompanied by changes in the composition and properties of the solids and pore fluid; $(b)$ a reduction in the solids mass (volume) due to loss of susceptible organic matter, as reflected by the reduction in TVS; (c) a reduction in plasticity; (d) an increase in specific gravity (see Figure 3(a)) and, hence, the bulk and dry densities achieved (assuming the biogas produced internally escapes); and (e) a reduction in the $O W C$ for compaction value, accompanied by an increase in the $\rho_{\mathrm{d}_{\max }}$ value achieved (Diliūnas et al., 2010; O'Kelly, 2005a, 2006, 2008b; Zhan et al., 2014). Furthermore, the degradation and loss of organic matter, which typically has extremely high water-holding capacity, correlates with reductions in natural water content and 
void ratio values. For instance, from field and laboratory investigations on the $15 \mathrm{~m}$ deep very soft sewage sludge deposit at Chengdu Changan landfill, Zhan et al. (2014) reported that the TVS (18.5-51.8\%) showed a decreasing trend (indicating greater levels of degradation) with depth, since the material had biodegraded on-site for longer periods and inorganic matter in the sludge pit had also tended to settle under gravity. The water content (210-790\%) also showed a decreasing trend with depth on account of the decreasing organic matter content and selfconsolidation of the deposited material. Bulk density and specific gravity showed increasing trends with depth, correlating with the measured water content and TVS profiles presented.

High $\mathrm{pH}$ has been widely used as an indicator of biochemical stabilisation because a $\mathrm{pH}>11$ leads to the immobilisation of heavy metals, the destruction of pathogens and lowering of microbial activity (Bednarik et al., 2004; Samaras et al., 2008). Conversely, a decline in $\mathrm{pH}$ can lead to a surge in the biodegradation of organic matter. As described in 'Management of these waste streams and principal disposal options' section, biosolids and sewage sludge amended with additives such as lime, fly ash, cement or slag can be used as structural fill material in road embankments (Arulrajah et al., 2013; Disfani et al., 2013, 2015; Wanigaratne and Udamulla, 2012), with special protection required to mitigate against potential leaching/flow to adjoining water bodies. Because the organic matter content of biosolids and sewage sludge materials is invariably very high, limiting the rate of biodegradation to achieve acceptable long-term biodegradation-induced settlements is important for such applications, and therefore, maintaining a $\mathrm{pH}$ of >11 is necessary (Disfani et al., 2015; Kayser et al., 2011).

\section{Compressibility}

Although the primary focus of this paper is on strength and its determination for efficient landfill disposal of biosolids, sewage sludge and WTR materials, this section presents a summary of their characteristic compressibility, consolidation and permeability behaviour/properties. Experimental investigations have been reported by Aydilek et al. (2000), O'Kelly (2005a, 2006, 2008b), Chen et al. (2014), Lin et al. (2014) and Zhan et al. (2014), to name a few, for biosolids and sewage sludge materials and by Wang et al. (1992), Wang and Tseng (1993), O'Kelly (2008a, 2010, 2016a) and O'Kelly and Quille (2009) for alum WTR materials. Recommendations on laboratory consolidation and permeability testing of biosolids and sewage sludge materials are presented in O'Kelly (2016a). The reader is referred to these publications for additional information to that presented below. Further, O'Kelly (2005a, 2006) described the use of an experimental setup that included a hydraulic consolidation cell $250 \mathrm{~mm}$ in diameter to investigate the rate of biogas production and the resulting increase in pore fluid pressure over time for various drainage provisions and controlled environmental conditions.

\section{Consolidation}

Although highly compressible (e.g. alum WTR 5 and 6 materials dewatered using centrifuge and sand-drying methods, respectively, had reported compression index values of $6 \cdot 7$ and $5 \cdot 2$ (Wang et al., 1992)), saturated biosolids, sewage sludge (O'Kelly, 2008b, 2016a) and alum WTR (O'Kelly, 2008a, 2010; O'Kelly and Quille, 2009) materials consolidate very slowly on account of their fine grading, high organic matter contents and distinctive microstructures, with a significant proportion of the solid particles (flocs) comprised of aggregated clay-sized organic matter and containing significant volumes of interstitial water (O'Kelly, 2013a). For biosolids and sewage sludge, another major factor for the very slow consolidation rate is the composition and viscous gel-like nature of the nonNewtonian pore fluid that contains fine suspended solids and the effect of gas bubbles generated internally by ongoing biodegradation (Klein and Sarsby, 2000; O'Kelly, 2008b, 2013a, 2016a; Sarsby, 2005). According to Sarsby (2005), each solid particle in a sewage sludge material is surrounded by thick polysaccharide liquor that is linked to a particle by a series of calcium bridges and tends to restrict the flow in between the solids. The coefficient of consolidation $\left(c_{\mathrm{v}}\right)$ values for these materials generally decreases dramatically with increasing $\sigma_{\mathrm{v}}^{\prime}-$ for example, from $c_{\mathrm{v}}$ of $\sim 0.35 \mathrm{~m}^{2} /$ year to $0 \cdot 003-0.03 \mathrm{~m}^{2} /$ year for $\sigma_{\mathrm{v}}^{\prime}$ increasing from 3 to $100 \mathrm{kPa}$ for sewage sludge 1 (O'Kelly, 2008b) and from $c_{\mathrm{v}}=0 \cdot 1-0 \cdot 7 \mathrm{~m}^{2} /$ year for $\sigma_{\mathrm{v}}^{\prime}=$ $1-5 \mathrm{kPa}$ (Sarsby, 2005), decreasing to $0.075 \mathrm{~m}^{2} /$ year at $\sigma_{\mathrm{v}}^{\prime}=10 \mathrm{kPa}$ (Klein and Sarsby, 2000) and to $0.02 \mathrm{~m}^{2} /$ year at $\sigma_{\mathrm{v}}^{\prime}=30 \mathrm{kPa}$ (Sarsby, 2005 ) for aged (>17 years) sewage sludge having a TVS value of $51 \%$. In other words, with increasing $\sigma_{\mathrm{v}}^{\prime}$, the secondary compression becomes increasingly dominant over the primary consolidation, with the former including a significant contribution arising from ongoing biodegradation (O'Kelly, 2005a). For greater levels of biodegradation, the secondary compression and biodegradationinduced contributions reduce, with the result that the contribution of primary consolidation to the overall deformation response increases.

For alum WTR materials, another major factor for their very slow consolidation rate is the electrovalent character of the aluminium (III) $\left(\mathrm{Al}^{3+}\right)$ ion (binds a greater number of water molecules within its aluminium hydroxide matrix state), its exceptionally high affinity for water compared with other coagulants (O'Kelly, 2008a; Wang et al. 1992; Wang and Tseng, 1993) and the fact that alum flocs are generally slightly larger and more compact than ferric flocs (Vesilind and Martel, 1990). For these reasons, alum WTR is more difficult to dewater compared with iron WTR and lime-softening sludge materials. According to Raghu and Hsieh (1986), lime sludge is relatively easy to dewater, with Fei et al. (2016) reporting measured $c_{\mathrm{v}}$ values for lime-softening sludge 2 material that were eight to nine orders of magnitude greater than the range of $0 \cdot 1-0 \cdot 4 \mathrm{~m}^{2} /$ year reported by O'Kelly (2008a) for alum WTRs $1-3$ for $\sigma_{\mathrm{v}}^{\prime}=3-200 \mathrm{kPa}$.

O'Kelly (2016a) urged caution on the use of classical consolidation theory for the analysis/interpretation of experimental data gathered for biosolids and sewage sludge materials. By contrast, the strain against elapsed time data curves obtained from the one-dimensional compression testing of alum WTR 1-3 materials were typical of organic clay, with primary consolidation generally remaining dominant over the secondary compression for 
higher $\sigma_{\mathrm{v}}^{\prime}$, and closely followed the characteristic shape given by the Terzaghi consolidation theory for inorganic soils when plotted on the square root or logarithm of time plots (O'Kelly, 2008a; O'Kelly and Quille, 2009). Further, the primary consolidation and secondary compression phases for the alum WTRs 1-3 were readily discernible using standard curve-fitting analyses, and good agreement was reported between the time periods required for substantial completion of consolidation deduced from standard curve-fitting analyses of strain-time curves and pore water pressure measurements (O’Kelly, 2008a).

\section{Permeability}

Laboratory permeability coefficient values for consolidated biosolids, sewage sludge and alum WTR materials are typically of the order of $10^{-9}$ to $10^{-11} \mathrm{~m} / \mathrm{s}$, exhibiting inverse relationships with $\sigma_{\mathrm{v}}^{\prime}$ on a bilogarithmic plot - for example, for alum WTR 5, the permeability coefficient value decreased from $8 \times 10^{-8}$ to $3 \times$ $10^{-10} \mathrm{~m} / \mathrm{s}$ for $\sigma_{\mathrm{v}}^{\prime}$ increasing from 1.7 to $541 \mathrm{kPa}$ (Wang and Tseng, 1993). Following conventional soil mechanics theory, the permeability coefficient for sewage sludge 1 and alum WTR 1-3 materials exhibited approximately direct relationships with void ratio (and hence water content) on a semi-logarithmic plot (O'Kelly, 2008a, 2008b, 2010; O'Kelly and Quille, 2009). In comparing oedometer results for sewage sludge 1 material at different states of biodegradation (namely TVS of 55 and 70\%), O'Kelly (2008b) found that the more strongly degraded material had greater permeability initially, but its permeability coefficient value remained extremely low overall, ranging from $10^{-9}$ to $10^{-12} \mathrm{~m} / \mathrm{s}$.

Compared with consolidated material, standard Proctor-compacted biosolids, sewage sludge and alum WTR materials have significantly greater permeability coefficient values of the order of $10^{-7} \mathrm{~m} / \mathrm{s}$ (Arulrajah et al., 2011; Disfani et al., 2015; O'Kelly, 2016a; Roque and Carvalho, 2006; Stone et al., 1998) on account of the network of large pore voids between the peds facilitating preferential flow of pore fluid.

\section{Settlement predictions}

Anticipated amounts and rates of settlement for biosolids, sewage sludge and WTR deposits can be predicted from the summation of the immediate settlement, primary consolidation settlement, secondary compression (mechanical creep) settlement and, in the case of biosolids and sewage sludge deposits, associated biodegradation-induced settlement. The contributions of the first three components listed are typically estimated from the results of oedometer tests. For predictions of the biodegradation-induced settlement, Disfani et al. (2013) presented an analytical method adopted from one proposed for sanitary landfills by Chakma and Mathur (2007), which requires knowledge of the water content, $\mathrm{pH}$ value, biodegradable fraction, temperature and biodegradation rate (dependent on age) of the placed biosolids/sewage sludge material. The method showed that the rate of biodegradationinduced settlement for biosolids fill reduces with a reduction in $\mathrm{pH}$, and further, the time taken for the full process of biodegradation decreases dramatically with $\mathrm{pH}$ for values between
$\mathrm{pH} 0$ and 6, but increases exponentially with $\mathrm{pH}$ for values between pH 8 and 14 (Disfani et al., 2013).

\section{Shear strength}

\section{Strength measurement}

The principal approaches to the determination of the shear strength of dewatered sludge and residue materials are fall cone, vane shear, pocket penetrometer, direct simple shear, unconfined compression and triaxial compression. Early research work on this topic includes the use of fall cone (Geuzens and Dieltjens, 1991a, 1991b; Loll, 1986) and laboratory vane (Geuzens and Dieltjens, 1991a, 1991b; Koenig and Bari, 2001; Koenig and Kay, 1994, 1995; Loll, 1991) apparatuses for testing the suitability (strength evaluation) of dewatered sewage sludge materials for landfilling. The fall cone apparatus (e.g. see BSI (1990a) and Geonor (2015)) and the miniature, handheld and on-site shear vane apparatuses (BSI, 1990b, 1990d) are particularly attractive to operators of water treatment plants/WWTPs and landfills in performing strength testing for fine slurry and plastic materials since these mechanical tests can be performed relatively quickly, in both laboratory (Kayser et al., 2011; Klein and Sarsby, 2000; O'Kelly, 2006, 2013a, 2014a) and field (Voß, 1993; Zhan et al., 2014) settings, with good repeatability.

\section{Fall cone approaches}

For the fall cone method, a stationary contacting cone is allowed to fall under its own weight and penetrate into the soil testspecimen (average strain rate of the order of $\sim 10^{6} \% / \mathrm{h}$ (Koumoto and Houlsby, 2001)), with the measured penetration depth related to the static (i.e. low strain rate) undrained shear strength $s_{\mathrm{ur}}$, according to the following equation

1. $s_{\mathrm{ur}}=\frac{K W}{h^{2}}$

where $W$ is the weight of the fall cone, $h$ is its depth of penetration into the soil test specimen and $K$ is the cone factor, as defined by Hansbo (1957).

This test method has been standardised and adopted in many countries as the preferred approach to determining the $L L$ (e.g. using the $80 \mathrm{~g} 30^{\circ}$ cone in accordance with BSI (1990a)), the plastic strength limit $P L_{100}$ (Haigh et al., 2013; Kyambadde and Stone, 2012; Sivakumar et al., 2015) and the undrained shear strength of intact and remoulded clay for different water contents within the plastic range (e.g. using the $80 \mathrm{~g} 30^{\circ}$ (BSI, 1990a), $100 \mathrm{~g}$ $30^{\circ}$ or $400 \mathrm{~g} 30^{\circ}$ cones (Geonor, 2015)) and to determine sensitivity (i.e. ratio of undisturbed strength to remoulded strength). However, drawbacks for the testing of highly organic soils include the following: (a) there is a dearth of knowledge regarding appropriate cone factor $(K)$ and adhesion factor $(\alpha)$ values (O'Kelly, 2016b) and (b) coarse fibres present in the soil may significantly affect the penetration of the falling cone into the test specimen, producing 
erratic results for repeat tests; hence, any coarse particles and fibres are generally removed beforehand by wet sieving, with the fall cone tests performed on the fraction passing the $425 \mu \mathrm{m}$ test sieve.

Considering the greater uncertainty regarding the $\alpha$ values appropriate for organic soils, and since the $60^{\circ}$ cone is less sensitive to variations in cone roughness (Koumoto and Houlsby, 2001; O'Kelly, 2016b), the author recommends that this cone is more suitable than the $30^{\circ}$ cone for strength determinations on biosolids, sewage sludge and WTR materials. For typical inorganic soils ( $\mu=0 \cdot 1$, where $\mu$ is the rate dependence parameter) and cone penetration depths ranging from 5 to $15 \mathrm{~mm}$, the $400 \mathrm{~g} 60^{\circ}$ fall cone provides for strength determinations covering the range of 5-50 kPa (O'Kelly, 2016b). Using the concept presented by Sivakumar et al. (2015), O'Kelly (2016b) suggested that a lighter $60^{\circ}$ cone which incorporates a falling distance (i.e. before the cone tip contacts the test specimen surface) can be used to achieve the same effect. Further, higher strength $(>50 \mathrm{kPa})$ and (/or) materials having greater strain-rate dependence can be tested by increasing the cone-falling distance for the same cone mass. Another option is to use pseudostatic cones that are mechanically driven into the soil test specimen (see Stone and Kyambadde (2007)) for direct undrained strength measurements.

\section{Vane shear}

Although there are various challenges and shortcomings with the shear vane testing of organic soil, in particular for more fibrous material (Landva, 1980b; Long and Boylan, 2012), the vane shear approach is widely used in practice, with the field vane providing a reliable index for establishing relative changes in strength with depth and (/or) time for landfilled material. For instance, Zhan et al. (2014) used a $75 \mathrm{~mm}$ wide $\times 150 \mathrm{~mm}$ high cruciform vane torqued at a rate of $6 \%$ min to determine the strength profile $\left(s_{\mathrm{u}_{\mathrm{vane}}}:<7 \mathrm{kPa}\right)$ with depth for very soft sewage sludge 5 material disposed in a $15 \mathrm{~m}$ deep pit. Handheld shear vanes $(25 \mathrm{~mm} \times 50 \mathrm{~mm}$ (Kayser et al., 2011; Lee, 2010) and $19 \mathrm{~mm} \times 28 \mathrm{~mm}$ (Arulrajah et al., 2013)) were used in testing biosolids 2 and aged biosolids 1 materials $\left(s_{\mathrm{u}_{\text {vane }}}:<15 \mathrm{kPa}\right.$ and $136-152 \mathrm{kPa}$, respectively). Compared with the handheld vane, the laboratory vane has a fixed frame, with a head assembly, which allows much slower rates of rotation of a miniature vane - for example, $12.7 \mathrm{~mm} \times 12.7 \mathrm{~mm}$ (Lee, 2010; O'Kelly, 2004, 2006, 2013a) and $25 \mathrm{~mm} \times 25 \mathrm{~mm}$ (O'Kelly, 2010, 2014a; O'Kelly and Quille, 2010) vanes torqued at $9 \%$ min were used in testing sewage sludge 1, biosolids 1 , biosolids 2 and alum WTR 4 materials. A small proportion of fibres in the test material can affect smaller vanes to a greater extent, potentially resulting in unconservative strength measurements (O'Kelly, 2013a). Shear vanes having larger blades are more appropriate for the testing of material with low strength. Also, compared with triaxial testing, standard laboratory vane testing does not provide a means of applying a confinement pressure to the test specimen and, hence, cannot simulate the on-site overburden condition. This is not the case for the field vane and, unlike laboratory undisturbed strength testing, does not require specialist sampling and specimen preparation techniques.

\section{Triaxial compression}

For the determination of the undrained strength in triaxial compression (i.e. $s_{\mathrm{u}_{\text {tivina }}}$ ), the test specimen is subjected to a hydrostatic confining pressure and then sheared at a constant rate of axial compression, without allowing specimen drainage (consolidation) to occur at any stage during the test procedure - that is, unconsolidated undrained (UU) test condition. This approach is generally best suited for materials having undrained strengths of at least $15 \mathrm{kPa}$. For intermediate and long-term conditions, isotropically consolidated undrained compression (CIUC) and isotropically consolidated drained compression (CIDC) triaxial tests are performed to determine pertinent effective stress strength parameter values. Examples include CIUC triaxial testing of sewage sludge 1 (O'Kelly, 2005d, 2006), biosolids 4 (GLSEC, 2003) and aged biosolids 1 (Arulrajah et al., 2013; Disfani et al., 2015) and CIUC triaxial testing of alum WTRs 1-6 and iron WTR 1 (O'Kelly, 2008a, 2010, 2011; O'Kelly and Quille, 2010; Wang et al., 1992) materials. Unless all-around specimen drainage (i.e. vertical two-way drainage and with specimen side drains fitted) is provided, the author has found that the triaxial consolidation stage (and, hence, the overall test duration) for CIUC and CIDC testing of biosolids and sewage sludge materials requires an excessively long period to achieve substantial dissipation of excess pore fluid pressure. This arises on account of the materials' extremely low permeability coefficient values, continuous generation of biogas internally due to ongoing biodegradation and partial or complete clogging of the drainage media because of the migration of fine soil particles, biogenic gas bubbles and bioclogging, as well as the progressive increase in viscosity of the pore liquid remaining within the test specimen due to filtering action (O'Kelly, 2016a). Further information and recommendations on triaxial consolidation and permeability testing of biosolids and sewage sludge materials, including the selection and verification of appropriate drainage media, are presented in O'Kelly (2016a).

Other factors being equal, the strength value mobilised for a given biosolids or sewage sludge material may be greater for smaller sized test-specimens on account of the scale effect associated with fibrous inclusions, with such behaviour also associated with fibrous peats (O'Kelly, 2015a). For bioactive biosolids and sewage sludge materials, it is questionable whether back-pressure saturated specimens remain in a saturated condition for the duration of undrained triaxial tests performed at low strain rates on account of the slow but steady accumulation of biogas generated internally. This would also have the effect of producing a reduction in the effective confinement pressure on the test specimen and, hence, its mobilised strength (O'Kelly, 2006, 2013b), in accordance with the effective Mohr-Coulomb strength criterion. For this reason, before preparing the sewage sludge $1(T V S=70 \%)$ specimens for CIUC triaxial testing, O'Kelly (2005a, 2006) pasteurised the test material by heat treatment at $80^{\circ} \mathrm{C}$ for a 5 -h period. It was argued that the measured effective stress strength parameter values were appropriate for the analysis of monofilled sewage sludge 1 material at that particular state of degradation, provided effective biogas control and leachate drainage systems were in place. 
Geotechnical Research

Volume 3 Issue 4
Geotechnics of municipal sludges and

residues for landfilling

O'Kelly

\section{Relating undrained strength measurements for different testing methods}

There is no direct and theoretically rigorous method for relating undrained strength values determined using different apparatus and for different test conditions, since individual strength measurement apparatuses approach the estimation of strength in distinct ways for example, compared with general ductile bulging of the test specimen in UU triaxial compression, a cylindrical failure surface develops for shear vane testing. Further, the mobilised strength in vane shear is dependent on the vane size, its aspect (width-to-height) ratio and the time to achieve shear failure $\left(t_{\mathrm{f}}\right)$, which is a function of the torsional stiffness of the spring used in the vane apparatus, speed of the drive motor to the vane shaft and also the undrained strength of the test material (O'Kelly, 2013b, 2013a). For triaxial testing, the mobilised strength is dependent on the stress path, confinement pressure (see 'Unsaturated condition of biosolids and sewage sludge' section), specimen drainage condition, strain rate and the failure criterion adopted for its determination (often taken as the shear resistance for $20 \%$ axial strain unless peak resistance is mobilised beforehand). Besides water content, other important factors determining the mobilised undrained strength for a given test material are its degree of saturation and level of compaction.

For demonstration purposes, Figure 5(a) shows the distinctly different shear responses for physically identical specimen pairs of sewage sludge 1 material tested in vane shear $(12.7 \times 12.7 \mathrm{~mm}$ vane rotated at $9 \% \mathrm{~min}$ ) and UU triaxial compression specimens of $38 \mathrm{~mm}$ dia. $\times 76 \mathrm{~mm}$ length, $100 \mathrm{kPa}$ cell pressure and $1.2 \% / \mathrm{min}$ axial strain rate) for the same $t_{\mathrm{f}}$ value of $\sim 12.5 \mathrm{~min}$. For these specific test conditions, noting the $100 \mathrm{kPa}$ cell pressure for the

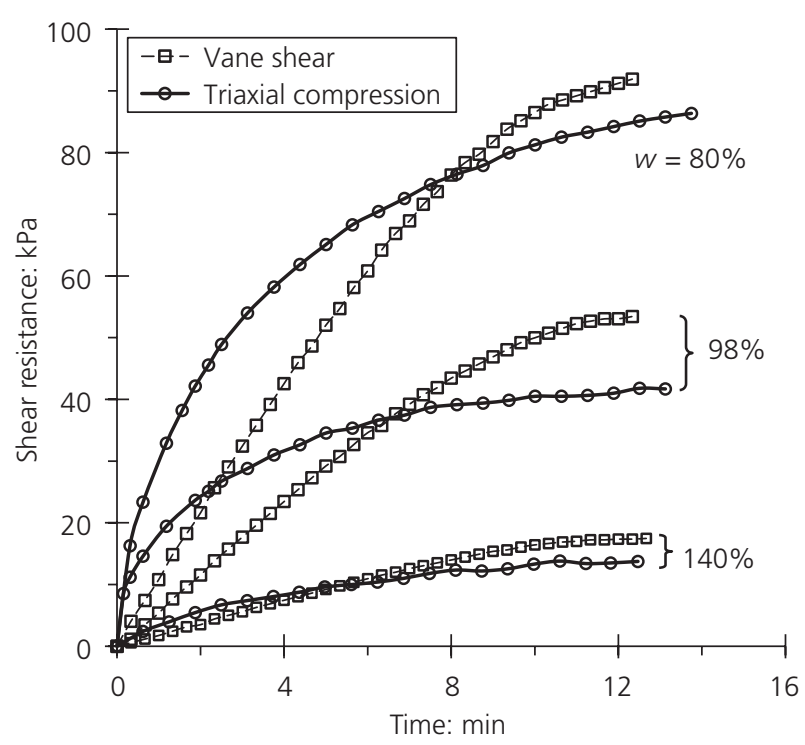

(a)
Figure 5. Vane and triaxial strengths mobilised for sewage sludge 1 and a time to failure $\left(t_{f}\right)$ of $\sim 12.5 \mathrm{~min}$ : (a) shear resistances of physically identical specimen pairs (adopted from O'Kelly (2013a)); triaxial specimens, the strength mobilised for sewage sludge 1 in vane shear was 1.21 times greater than that mobilised in UU triaxial compression (Figure 5(b)). Although the vane head rotation remained unchanged at $9 \%$ min for later tests, the $t_{\mathrm{f}}$ value for vane shear increases with reducing water content (increasing strength). For water content reducing from 150 to $80 \%$ (corresponding to soft and very stiff consistency states, respectively, for this particular material), the strength mobilised in vane shear generally increased from $1 \cdot 19$ to 1.40 times greater than that mobilised in UU triaxial compression (O'Kelly, 2006, 2013a).

Figure 6 shows remoulded undrained strength-water content relationships deduced using the $80 \mathrm{~g} 30^{\circ}$ fall cone, the $25 \mathrm{~mm} \times$ $25 \mathrm{~mm}$ laboratory vane torqued at $9 \%$ min and test specimens of $38 \mathrm{~mm}$ dia. $\times 76 \mathrm{~mm}$ length (sewage sludge 1 and alum WTR 4) or $76 \mathrm{~mm}$ dia. $\times 150 \mathrm{~mm}$ length (biosolids 2 at $w=330 \%$ ) sheared under 100 and $300 \mathrm{kPa}$ cell pressures in UU triaxial compression. As expected, strength measurements for these materials are particularly sensitive to strain rate on account of their high strain rate dependence (see 'High strain rate dependence' section). For the biosolids and sewage sludge, greater strength is mobilised for higher confinement pressure (see Figure 6(a) and 'Unsaturated condition of biosolids and sewage sludge' section), since these materials invariably occur in a partially saturated state. By contrast, the vane and triaxial strength relationships (0 and $100 \mathrm{kPa}$ confinement pressures, respectively) for the saturated alum WTR material in Figure 6(b) showed reasonable agreement. Referring to Figure 6(a), for the same cell pressure of $100 \mathrm{kPa}$ and strain rate (i.e. 1.6 and $2.0 \% / \mathrm{min}$ data), the standard Proctor-compacted sewage sludge 1 and saturated biosolids 2 materials mobilised different triaxial

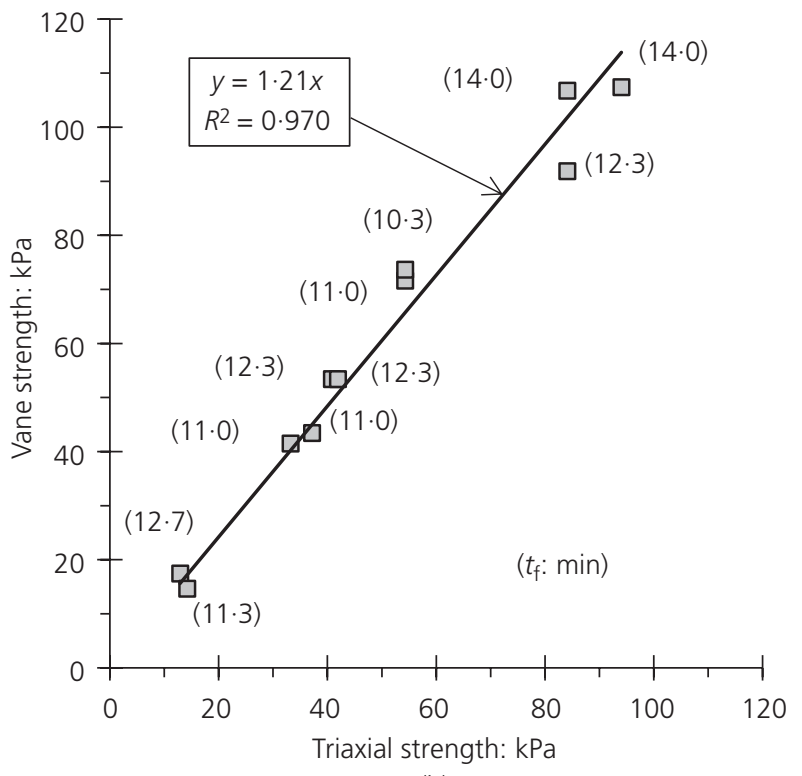

(b)

(b) correlation between undrained strengths deduced for $38 \mathrm{~mm}$ dia. triaxial specimens, with $100 \mathrm{kPa}$ cell pressure, and $12.7 \mathrm{~mm}$ dia. cruciform vane (adopted from O'Kelly (2013a)) 


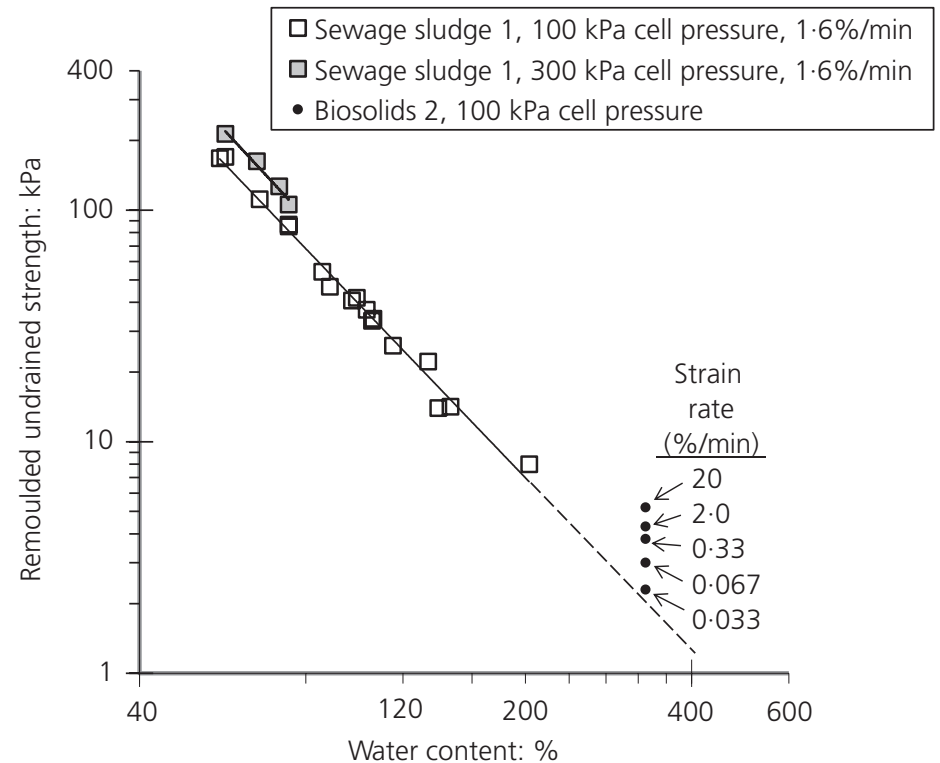

(a)

Figure 6. Undrained strength-water content relationships deduced using different strength measurement apparatus:

(a) sewage sludge 1 and biosolids 2 in UU triaxial compression

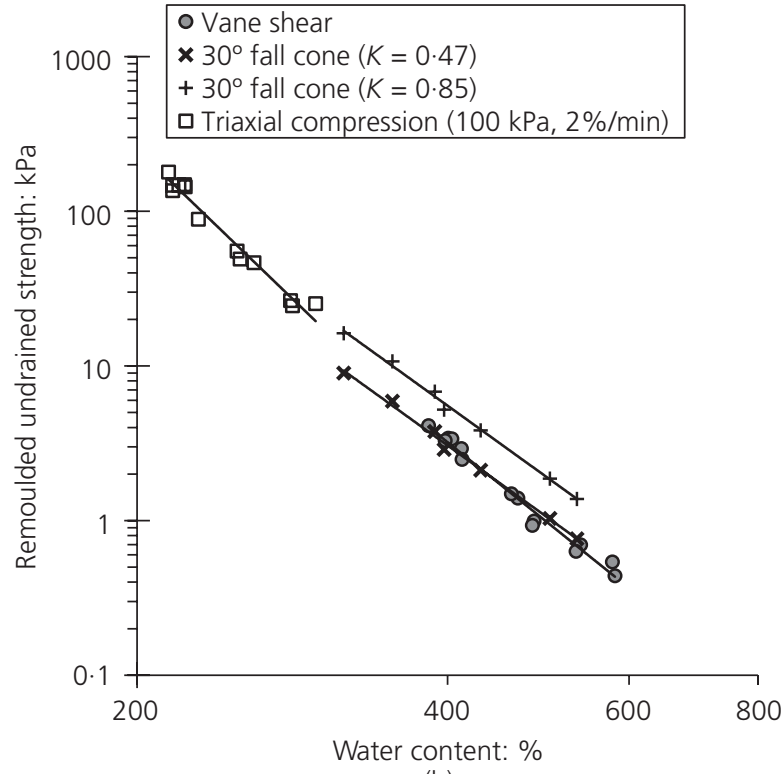

(b)

(adopted from O'Kelly (2013b)) and (b) saturated alum WTR 4 (adopted from O'Kelly (2014a, 2016b)) strength values of 2.2 and $4.3 \mathrm{kPa}$, respectively, at $330 \%$ water content, which may be explained, at least in part, by the fact that despite having similar TVS values, these materials had been sourced from different WWTPs and, therefore, had their own distinct compositions and geomechanical behaviours. Regarding the biosolids 2 data (undrained strengths: $\leq 5 \cdot 2 \mathrm{kPa}$ ), the author would have some general reservations on the appropriateness of routine triaxial testing for such very soft material, including the requirement for more specialised specimen preparation technique, necessary corrections for the sealing membrane that encloses the test specimen being of the same order of magnitude as the measured deviatoric stress and greater control and measurement accuracy requirements for the apparatus and instrumentation.

Other examples relating strength measurements for different testing methods reported in the literature include testing biosolids 2 material without lime and with $20 \%$ lime additive. The respective strengths mobilised using the $25 \mathrm{~mm}$ wide $\times 50 \mathrm{~mm}$ long Geonor handheld vane for $t_{\mathrm{f}} \approx 5 \mathrm{~s}$ were 1.8 and 1.6 times greater than those mobilised for specimens of $76 \mathrm{~mm} \mathrm{dia} . \times 150 \mathrm{~mm}$ length sheared at $0.33 \%$ axial strain/min under $100 \mathrm{kPa}$ cell pressure in UU triaxial compression (Kayser et al., 2011). Using data presented by Kayser et al. (2011), O'Kelly (2013b) showed that for these particular vane and triaxial test conditions, but for no applied cell pressure, deduced vane strength and unconfined compression strength values were in good agreement, again demonstrating that mobilised undrained strength for biosolids material generally increases with confinement pressure. In testing the same biosolids material, Lee (2010) reported that respective strengths mobilised by the $12.7 \times$ $12.7 \mathrm{~mm}$ laboratory vane rotated at $9 \% \mathrm{~min}$ and the same handheld vane apparatus (with $t_{\mathrm{f}} \approx 5 \mathrm{~s}$ ) used by Kayser et al. (2011) were typically 2.0 and 1.7 times greater than those mobilised in UU triaxial compression. Further, the laboratory vane produced strength readings that were typically 1.2 times greater than those mobilised by the handheld vane (Lee, 2010).

In testing biosolids material that had been treated with calcium hydroxide and ferric chloride before the dewatering process at the WWTP, Voß (1993) reported that strengths mobilised for the $12 \cdot 7 \times$ $12.7 \mathrm{~mm}$ laboratory vane rotated at $10^{\circ} / \mathrm{min}$ were between two and four (average of 2.8 ) times greater than those mobilised for specimens of $36 \mathrm{~mm}$ dia. $\times 80 \mathrm{~mm}$ length sheared at $0.83 \%$ axial strain/min in UU triaxial compression. Koenig and Bari (2001) reported that for a sewage sludge material investigated the strength mobilised for the pocket shearometer was approximately 1.27 times greater than that mobilised for the laboratory vane. In testing biosolids amended with quicklime, Horn (1990) reported that strengths mobilised for the $12.7 \times 12.7 \mathrm{~mm}$ laboratory vane were between 1.6 and 2.0 times greater than those mobilised for 50-127 mm wide handheld vanes having an aspect ratio of two.

Referring to Figure 6(b) for saturated alum WTR 4 material, the value of the cone factor ( $K$ in Equation 1) was adjusted in the study by O'Kelly (2016b) to obtain a one-to-one correspondence between the fall cone and shear vane strength relationships. The deduced $K$ value of 0.47 was significantly less than the value of 0.85 (Wood, 1985) generally used for remoulded inorganic fine-grained soil. This was explained by the significantly higher strain rate dependence of the alum WTR compared with most inorganic soils (see 'High strain rate dependence' section). As evident from Figure 
6(b), the use of a $K$ value of 0.85 in strength calculations for this WTR material would grossly overestimate its undrained strength. Hence, for these unconventional geomaterials, it is important to correlate fall cone results (i.e. achieve one-to-one correspondence) with some static undrained strength data (e.g. vane shear or UU triaxial compression) in order to establish an appropriate $K$ value for strength calculations. Further, from the investigations described earlier, it is clear that mobilised strengths are dependent on the test material and its physical state, the strength measurement apparatus employed and the specific test conditions adopted, as are the values of adjustment factors used to relate mobilised strengths determined for different strength measurement apparatus and different test conditions. For a given test material, smaller vanes generally produce higher strength readings, particularly at lower water content, which can be explained, at least in part, by the fibrous nature of some biosolids and sewage sludge materials. In other words, small vanes may produce unconservative strength determinations for material having fibrous inclusions. Further, biosolids and sewage materials generally occur in a partially saturated condition, such that the specimen confinement pressure can significantly increase the mobilised strength (see 'Unsaturated condition of biosolids and sewage sludge' section).

\section{Characteristic strength behaviour/properties of municipal sludge and residue materials}

As highly organic materials, there are general similarities between the strength behaviour/properties of biosolids, sewage sludge and WTR materials, which are described in this section, including the unsaturated condition and gel-like pore fluid of biosolids and sewage sludge, large strains required to mobilise peak shear resistance, high effective friction angle $\left(\phi^{\prime}\right)$ and strain rate dependence, strong thixotropic behaviour and strength reduction potential due to swelling on account of compaction-induced overconsolidation and continuing biogas generation internally. These materials also have some general similarities with peat materials, with critical reviews of various total and effective stress strength testing for peat materials presented by Long (2005), Long and Boylan (2012), Mesri and Ajlouni (2007), O'Kelly and Zhang (2013) and O'Kelly (2015a), to name a few. Although useful insights may be gained from analogies with peats and other highly organic soils, a degree of caution is required since significant physical differences exist between these materials, including the generally higher organic and fibre contents of peat and its significantly slower rate of biodegradation on-site (O'Kelly and Pichan, 2014; Wardwell et al., 1983) compared with biosolids and sewage sludge.

\section{Unsaturated condition of biosolids and sewage sludge}

As mentioned previously, gas generated internally by ongoing or reactivated biodegradation for $\mathrm{pH}$ of $<11$, and which remains trapped within biosolids and sewage sludge, reduces the degree of saturation of these materials, such that they do not behave as $\phi_{\mathrm{u}}=0^{\circ}$ materials under shearing (where $\phi_{\mathrm{u}}$ is the undrained friction angle (total stress)) (Kayser et al., 2011; O'Kelly, 2013a; 2013b). In other words, the Mohr-Coulomb failure envelope for these materials has a concave curvature (i.e. becoming less steep for increasing confinement pressure), with greater undrained strength mobilised for higher confinement pressure (e.g. see triaxial data for sewage sludge 1 in Figure 6(a)). Hence, the cell pressure applied in triaxial tests should simulate typical overburden conditions, with unconfined compression providing a lower-bound strength value for a given strain rate (O'Kelly, 2013b). Further, a build-up of pore fluid pressure occurring with time on account of biogas trapped within the landfill body would have the effect of producing a reduction in the effective overburden stress and, hence, the consolidation rate and shear strength (according to the effective stress Mohr-Coulomb strength criterion) (O'Kelly, 2005a, 2006, 2013b), which if left unchecked, may ultimately lead to structural instability problems for the landfill body.

Large strains required to mobilise peak shear resistance For plastic biosolids, sewage sludge and WTR materials, large shear deformations are required in laboratory strength tests to mobilise peak shear resistance. For example, as shown in Figure 7 for saturated alum WTR 4 material, typically $>20 \%$ axial strain is required to mobilise the peak deviatoric stress in UU triaxial compression. Where apparatus strain limitation arises, the ultimate shear stress (strength) can be found by the extrapolation of the triaxial test results using the hyperbolic formulation, first formulated by Kondner (1963), on the condition that the extrapolation is limited to $25 \%$ of the maximum measured shear strength for reliability reasons.

\section{High effective friction angle}

Compared with fine inorganic soils having similar plasticity (e.g. $\phi^{\prime}=5-10^{\circ}$ for montmorillonite (Mitchell and Soga, 2005)), the biosolids, sewage sludge and WTR materials have very high reported effective friction angle $\phi^{\prime}$ values. For instance, CIUC triaxial testing of back-pressure saturated, compacted specimens indicated $\phi^{\prime}=32-42^{\circ}$ for biosolids 4 (GLSEC, 2003),

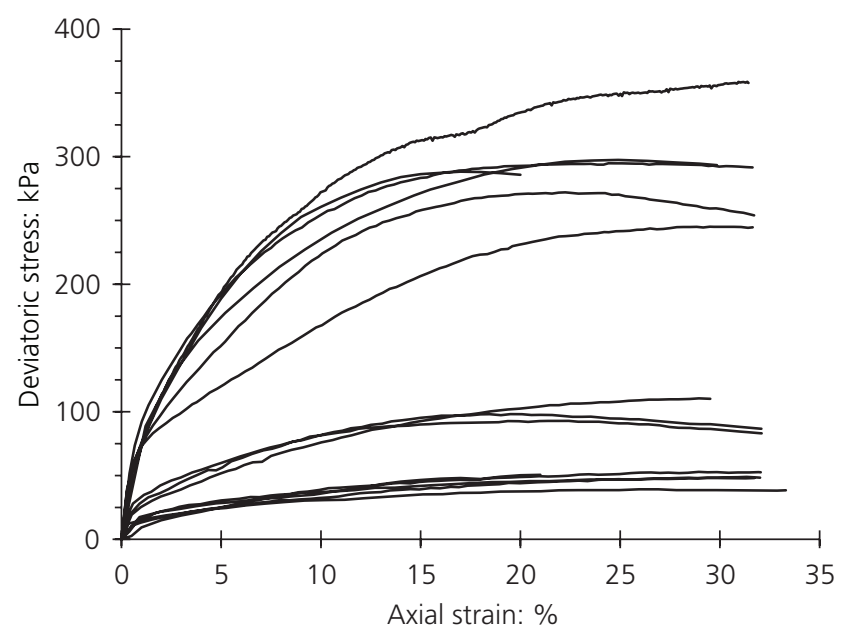

Figure 7. Deviatoric stress against axial strain for saturated alum WTR 4 material having water contents of $215-298 \%$ within plastic range (adopted from O'Kelly (2014a)) 
$33 \cdot 0-39 \cdot 6^{\circ}$ for aged biosolids 1 (Arulrajah et al., 2013) and $26 \cdot 5^{\circ}$ for aged biosolids 3 (Maghoolpilehrood et al., 2013). Further, compared with material sampled from the WWTP $($ TVS $=70 \%)$, CIUC triaxial testing of saturated pasteurised specimens of sewage sludge 1 that had been consolidated one-dimensionally from a slurry condition indicated that more degraded material $($ TVS $=55 \%)$ had a higher $\phi^{\prime}$ value (increasing from $32^{\circ}$ to $\left.37^{\circ}\right)$ (O'Kelly, 2005d, 2006). For saturated WTR materials, CIUC triaxial testing produced $\phi^{\prime}$ values of $39-44^{\circ}$ (alum WTRs $1-3$ (O'Kelly and Quille, 2010)), $\phi^{\prime}=44^{\circ}$, with $c^{\prime}=77 \mathrm{kPa}$ (alum WTR 9 (Roque and Carvalho, 2006)) and $\phi^{\prime}=42 \cdot 3-44 \cdot 0^{\circ}$, with $c^{\prime}=6 \cdot 9-8 \cdot 3 \mathrm{kPa}$ (iron WTR 1 and alum WTRs 5 and 6 (Wang et al., 1992)). As discussed in 'Intermediate and long-term conditions' section, these $\phi^{\prime}$ values are far too high for design purposes, and furthermore, the value of $c^{\prime}$ for different types of sludge and residue materials is usually negligible. For co-disposal with MSW, the value of $\phi^{\prime}$ for the composite material reduces significantly with increasing proportion of biosolids/sewage sludge material.

\section{High strain rate dependence}

Compared with most inorganic soils, the biosolids, sewage sludge and WTR materials exhibit significantly greater strain rate dependence of strength, with the strength mobilised during loading greater for higher strain rates (i.e. shorter $t_{\mathrm{f}}$ ). For instance, Figure 8(a) shows normalised UU triaxial compression strength data for various biosolids and an alum WTR material plotted against shear strain rate $(\dot{\gamma})$ values. The normalisation was against the triaxial strength value measured for the standard reference shear strain rate of $\dot{\gamma}_{0}=1 \% / \mathrm{h}$. For these materials, the value of the rate dependence parameter $\mu$, given by the gradient of the semi-logarithmic data plots, ranged from 0.2 to 0.4 (Figure 8(a)), compared with $0.1 \pm 0.05$ for most inorganic soils (Koumoto and Houlsby, 2001; Kulhawy and Mayne, 1990; Ladd and Foott, 1974). Note that similarly high $\mu$ values (e.g. $0 \cdot 28$ for amorphous peat having TVS $=98 \cdot 8 \%$ (O'Kelly, 2016b) have been reported for peat materials. Referring to Figure 8(a), biosolids 1 and 2 materials had $\mu$ values of $0 \cdot 38-0 \cdot 39$, meaning a tenfold increase in strain rate typically produced a $40 \%$ increase in UU triaxial compression strength.

Figure 8 (b) demonstrates the strain rate dependency of the vane strength for six sets of sewage sludge 1 specimens, each set having been prepared at the same water content and dry density, with greater vane strength mobilised for reduced $t_{\mathrm{f}}$ values. For fall cone strength testing, with a given cone angle and surface roughness, the value of the cone factor $K$ (and, hence, the undrained strength (given by Equation 1)) decreases with increasing strain rate dependence of strength. The practical significance of this was demonstrated by O'Kelly (2016b), with reference to a particular example for a $400 \mathrm{~g} 30^{\circ}$ fall cone having $\alpha=0.5$. For a cone penetration depth of $8.8 \mathrm{~mm}$, a $\mu=0 \cdot 1$ material would mobilise $s_{\text {ur }}=50 \mathrm{kPa}$, whereas a $\mu=0.3$ material would mobilise a lower $s_{\text {ur }}$ value of $\sim 29 \mathrm{kPa}$ - that is, the value of $K$ used in Equation 1 for the $\mu=0.3$ material is $\sim 74 \%$ smaller. According to numerical analysis presented by Hazell (2008), this assessment of the strength impact resulting from the difference in strain rate dependence values investigated generally applies for all values of the cone angle and adhesion factor $\alpha$. In other words, using this particular example for demonstration purposes, the strength value of $50 \mathrm{kPa}$ deduced for $\mu=0 \cdot 1$ material would

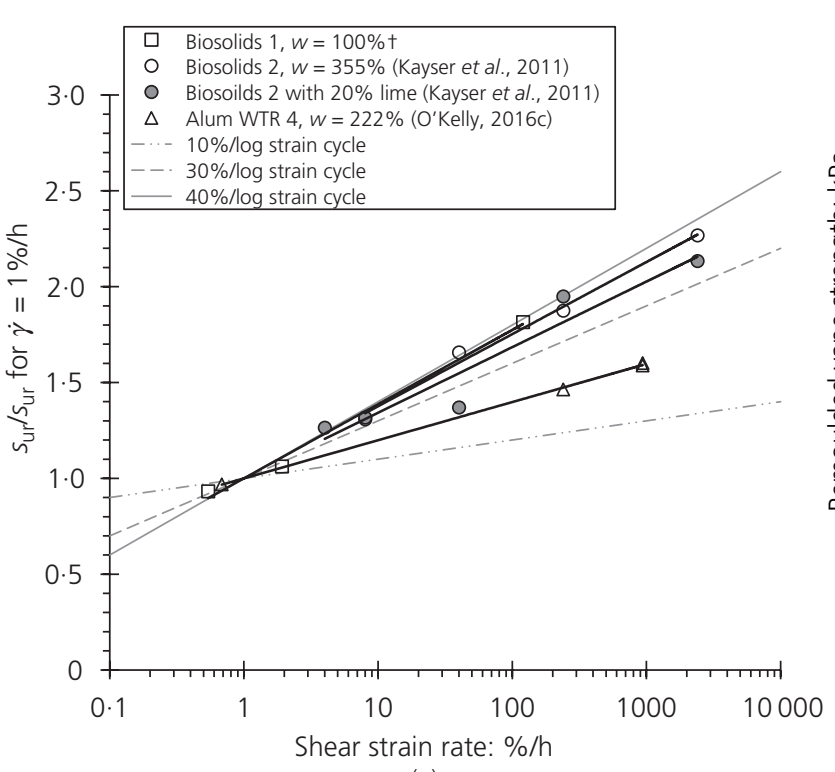

(a)

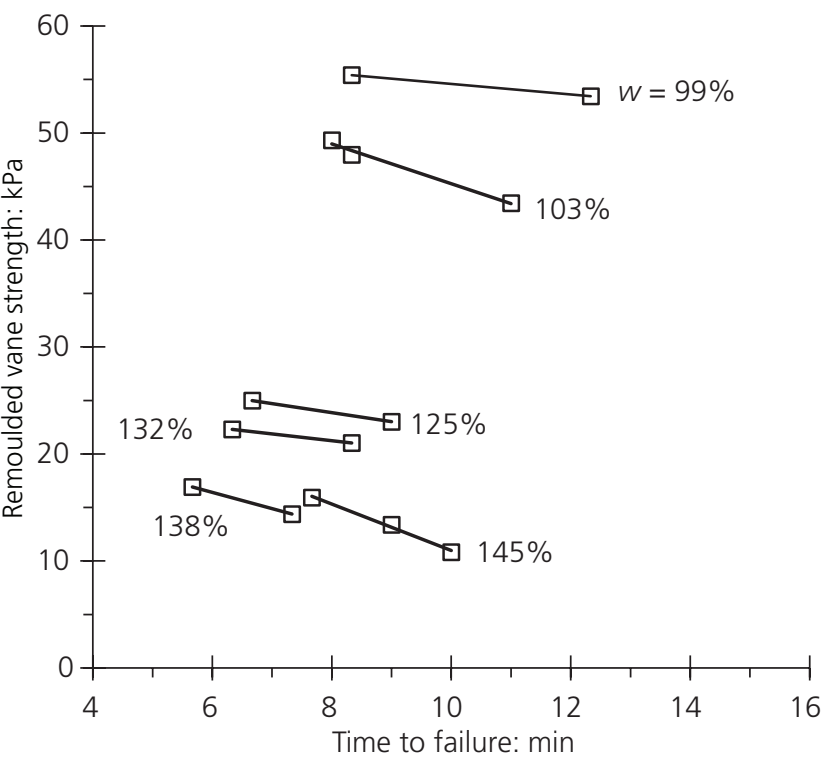

(b)

Figure 8. Strain rate dependence of strength: (a) normalised strength against shear strain rate in UU triaxial compression (adopted from O'Kelly (2016c)) and (b) mobilised vane strength

against time-to-failure for sewage sludge 1 (O'Kelly (2013a, 2013b)) (†from forthcoming article entitled 'Shear strength of biosolids for monofill design' by Oettle, O'Kelly and Ramos) 
indicate that it meets the minimum strength requirement for landfilling (i.e. $s_{\mathrm{ur}} \geq 50 \mathrm{kPa}$ for cohesive waste (EA, 2010), whereas if the material actually had a strain rate dependence value of $0 \cdot 3$, its undrained strength capacity would fall approximately $74 \%$ below this requirement. Further, the interpretation of fall cone data for undrained strength determinations is not straightforward in the cases of biosolids and sewage sludge of slurry consistency, because of the added complexity introduced by the viscous gel-like nature of the pore fluid in these materials (Klein and Sarsby, 2000; O'Kelly, 2013a, 2016b), described in the next section.

\section{Viscous pore fluid in biosolids and sewage sludge}

Compared with inorganic, WTR and other organic soil materials, the viscous pore fluid in biosolids and sewage sludge is a significant contributor to the mobilised strength for these materials in the slurry $(w>L L)$ and very soft consistency states, as demonstrated in Figure 9 for sewage sludge 1.

Methods of analyses were presented by O'Kelly (2013a) for estimating the contribution of the gel-like pore fluid to the mobilised strength and to determine more accurately the water content corresponding to the fall cone $L L$ condition, conventionally defined in terms of shear resistance (i.e. friction and bonding between the solids, excluding any strength contribution from the pore fluid). When fall cone strength determinations are not corrected for this gel strength contribution, the liquidity index ( $I_{\mathrm{L}}$, Equation 2$)$ has been shown as an unreliable indicator of sludge consistency - for example, for sewage sludge 3, Diliūnas et al. (2010) reported that laboratory testing gave $I_{\mathrm{L}}$ values ranging from 0.47 to 0.52 , whereas visual observations at the sludge storage site indicated that the same material was almost liquid.

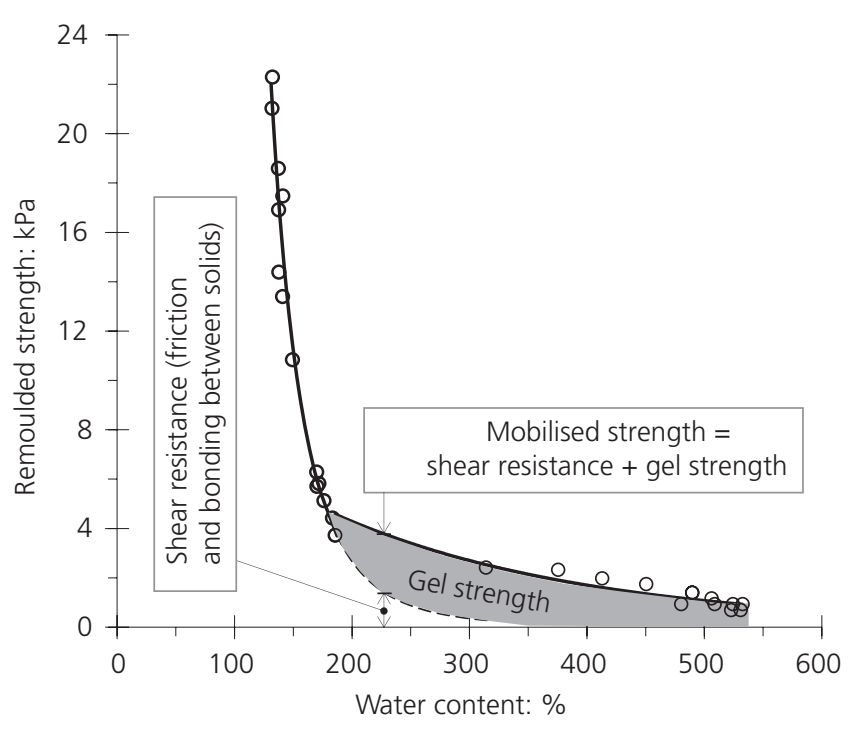

Figure 9. Vane strength against water content for sewage sludge 1 (adopted from O'Kelly (2013a))
2. $I_{\mathrm{L}}=\frac{w_{\mathrm{n}}-P L}{L L-P L}$

where $w_{\mathrm{n}}$ is the natural (on-site) water content and $L L$ and $P L$ are the liquid and plastic limits, respectively.

\section{Effect of chemical additives at WWTP}

Chemicals added during the water/wastewater treatment processes can significantly affect the strength and consolidation behaviours/ properties of the dewatered sludge and residue materials. For instance, over the water content range of $190-400 \%$ investigated, compared with non-chemically derived residue material, the alum WTR 2 material was found to have 10-20\% greater undrained strength, higher stress-strain modulus and marginally higher $\phi^{\prime}$ (O'Kelly, 2010, 2011, 2014a), with the mechanisms of charge neutralisation by adsorption, interparticle bridging and intertwining phenomena that brought about these improvements for the alum and polyelectrolyte additives used described by O'Kelly (2011). Further, the residue material without additives was more compressible $\left(C_{\mathrm{c}}\right.$ value of $5 \cdot 5$, compared with $3 \cdot 1$ measured for alum WTR 2) and was also found to consolidate at a quicker rate (O'Kelly, 2010, 2011, 2014a).

\section{Thixotropic behaviour}

Typical of fine-grained soils, the biosolids, sewage sludge and WTR materials are thixotropic in nature, as demonstrated in Figure 10. In other words, the undisturbed undrained strength and thixotropy strength ratio (Equation 3) increase with curing period, more rapidly during the first couple of weeks (Figure 10(a)), and for increasing liquidity index (Figure 10(b)), with significant effect for water contents nearer and above the $L L$ (i.e. $I_{\mathrm{L}}=1$ ) condition.

3. thixotropy strength ratio $=\frac{s_{\mathrm{u}(t)}}{s_{\mathrm{ur}}}$

where $s_{\mathrm{ur}}$ is the remoulded undrained strength and $s_{\mathrm{u}(t)}$ is the undisturbed undrained strength mobilised after time period $t$.

For a given $I_{\mathrm{L}}$ value, the increase in the thixotropy strength ratio with curing period plotted in Figure 10(b) appears to be broadly consistent for the four alum WTRs considered, with the limited data for iron WTR (1) suggesting that the thixotropy effect is significantly greater for alum WTR.

\section{Strength reduction due to compaction-induced overconsolidation}

Higher strengths are measured for soil with reducing water content. However, for the unsaturated as-compacted state under low on-site confinement stress state, inundation with water and the compactioninduced overconsolidation condition can result in swelling and strength reduction for material compacted on the dry side of $O W C$, such that a lower strength value can be mobilised compared with 


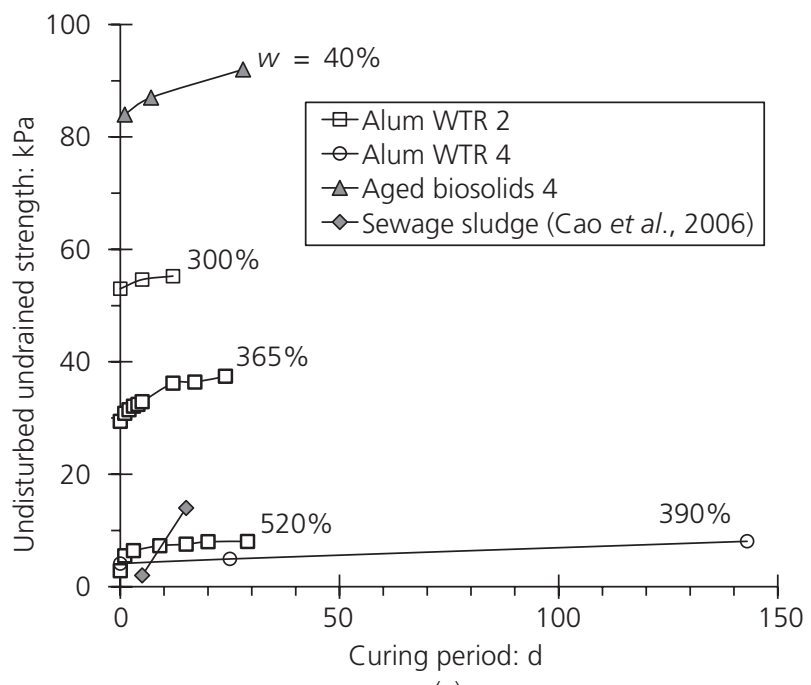

(a)

Figure 10. Thixotropic behaviour: (a) undisturbed vane strength for alum WTRs 2 and 4 (adopted from O'Kelly (2010, 2014a, 2016c)) and unconfined compression strength for aged biosolids 4 (Maghoolpilehrood et al., 2015) plotted against curing period and

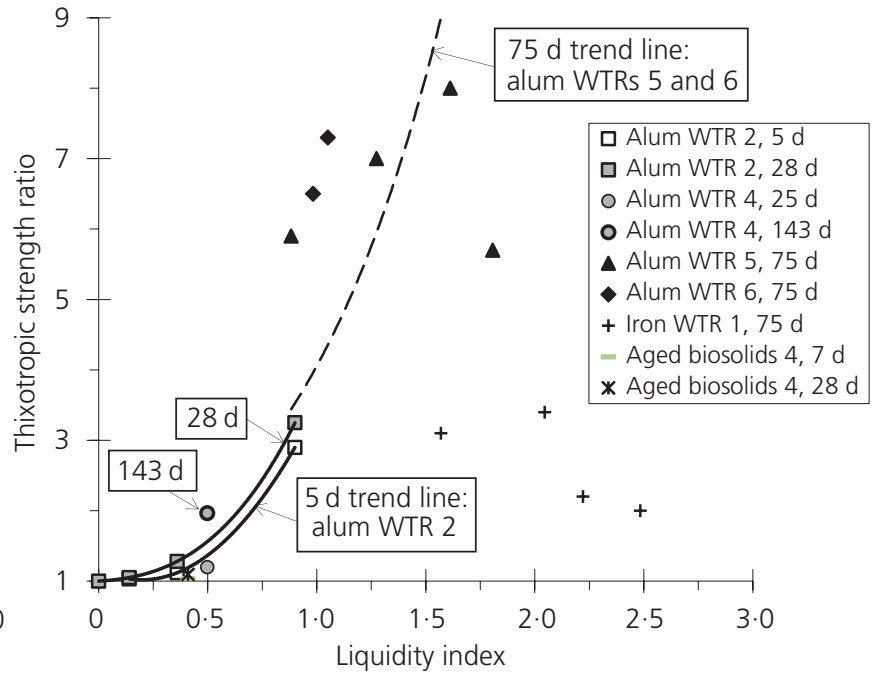

(b)

(b) thixotropy strength ratio against liquidity index, including alum WTRs 5 and 6 and iron WTR 1 data from Wang et al. (1992) measured using cone penetrometer the same material when compacted on the wet side of $O W C$. The effect can be significant for biosolids and sewage sludge materials (O'Kelly, 2004, 2005a, 2006) and has also been observed for some alum WTR materials (O'Kelly, 2010; O'Kelly and Quille, 2010). For instance, in a forthcoming article entitled 'Shear strength of biosolids for monofill design' by Oettle, O'Kelly and Ramos, the authors reported that the uptake of pore water for biosolids 1 specimens (modified Proctor compaction at the optimum water content of $59 \%$ to produce a $\rho_{\mathrm{d}_{\max }}$ value of $0.68 \mathrm{t} / \mathrm{m}^{3}$ ) during direct simple shear tests with applied vertical stress of 75 and $150 \mathrm{kPa}$ resulted in considerably lower mobilised strengths than material compacted at $100 \%$ water content. All the tested specimens were found to have approximately the same water content of $100 \%$ at the end of shearing. The lower saturated shear strength for material compacted at water contents on the dry side of $O W C$ is consistent with results presented by Mitchell and Soga (2005) for compacted clayey fills and was explained by the differences in the soil fabric arising from 'dry' against 'wet' compaction.

\section{Conceptual model towards explaining significant} undrained strength mobilised for extremely high water content

Building on an earlier model presented for sewage sludge by Klein and Sarsby (2000), O'Kelly (2014a) presented a conceptual model towards explaining the relatively high strength mobilised for alum WTR materials having extremely high water content. Shear strength is considered to be governed exclusively by the external water fraction (and not by the total amount of water evaporated by oven drying for water content determinations), which is comprised of free water and adsorbed water layer located within macropore spaces and around the aggregate flocs, respectively. In other words, the shear strength mobilised is considered independent of the internal water fraction (comprised of interstitial water located within microchannels and micropores, adsorbed water on surfaces within the aggregate flocs, chemically bound water and water of hydration). Internal water accounts for a significant proportion of the total water in alum WTR materials on account of the electrovalent character of the aluminium (III) ion (binds a greater number of water molecules within its aluminium hydroxide matrix state) (O'Kelly, 2008a; Wang and Tseng, 1993; Wang et al., 1992). Towards substantiating this model experimentally, O'Kelly (2014a) performed fall cone testing on alum WTR 4 slurry and the same material after blending for $10 \mathrm{~min}$ period using a domestic food liquidiser. For a given (total) water content value, the blended material was found to have inferior undrained strength on account of its relatively higher external water and lower internal water fractions produced by some shearing (disaggregation) of the flocs brought about by the blending action.

\section{Undrained strength requirements for landfilling}

The undrained strength relates to the short-term condition and is pertinent to trafficability, fill placement and compaction requirements and to ensure an adequate factor of safety $(F)$ value against the instability of the landfill slopes. Provided excess pore fluid pressures generated within the landfill body can readily dissipate by way of efficient well-maintained biogas extraction and leachate drainage systems, the $F$ value on slope instability generally increases over time on account of the strength gains that result from consolidation under the overburden pressure and thixotropic hardening behaviour of the undisturbed landfilled materials, although the strength gains (and changes in other engineering properties) may not be homogeneous throughout the sludge body (Diliūnas et al., 2010). Similar behaviour (i.e. 
strength heterogeneity) has been reported for peat deposits on account of non-uniform rates of decomposition on-site (Landva, 1980a; O'Kelly and Pichan, 2013; O'Kelly and Sivakumar, 2014).

\section{Monofilling}

For biosolids, sewage sludge and WTR monofills, minimum onsite undrained strengths of typically $50 \mathrm{kPa}$ are recommended for trafficability by landfill compactors and dump trucks and to achieve an adequate $F$ value against the instability of the landfill slopes (O'Kelly, 2004, 2005b, 2010; O'Kelly and Quille, 2010). Increasingly, in order to meet both geotechnical and environmental considerations for the monofilling of these materials, there is a tendency to require a minimum undrained strength of $50 \mathrm{kPa}$ (EA, 2010).

\section{Co-disposal at sanitary landfills}

For co-disposal at sanitary landfills, minimum vane strength of $20 \mathrm{kPa}$ (Loll, 1991) or $25 \mathrm{kPa}$ (Siedlungsabfall, 1993; Wichmann and Riehl, 1997) have been recommended for municipal sludge and residue materials. These materials are typically placed in thin layers and mixed and scarified on-site with the MSW material, which has the effect of reducing their water content, thereby increasing their shear strength. Geuzens and Dieltjens (1991a), for instance, reported that depending on the relative volume of sludge for disposal, WTR material in the Belgian-Flemish region was placed in sanitary landfills, either as packages or layers of up to $2 \mathrm{~m}$ thick, or as thin layers (which leads to a thorough mixing with the surrounding waste). Another approach used is introducing these materials of slurry or very soft consistency states into sanitary landfills as backfill for excavated trenches. According to Kayser et al. (2011), sludge and residue materials having shear strength of $>25 \mathrm{kPa}$ allow the use of tracked vehicles for their placement and compaction. Higher shear strength lowers the risk of slope instability and provides for the placement of larger volumes of these materials by increasing the allowable slope angle and fill depth.

\section{Sludge dewatering and solidification}

The levels of post-treatment dewatering necessary to achieve the undrained strengths reported in the 'Monofilling' and 'Co-disposal at sanitary landfills' sections can be achieved at the municipal works using recessed-plate filter press and belt dryer machines after the chemical conditioning of the sludge by-product (O'Kelly, 2010; O'Kelly and Quille, 2010). Centrifuge and belt press machines generally cannot reduce the water content sufficiently. A novel on-site dewatering technique, employing vacuum preloading with prefabricated vertical drains, was successfully trialled for aged sewage sludge 5 material deposited in a disposal pit, with the water content reduced from $860 \%$ initially to $140-450 \%$ posttreatment (Lin et al., 2014). Alternatively, these materials can be solar dried over longer periods in drying beds (Stone et al. 1998) and (or) stockpiles (Arulrajah et al., 2011, 2013), depending on the prevailing environmental conditions.

In many countries, off-site or on-site soil-conditioning techniques using additives such as lime, fly ash, cement and slag can be used to solidify/stabilise biosolids, sewage sludge and WTR stockpiles or deposits sufficiently and expeditiously. Of these additives, lime is the most commonly employed, but because of its high associated cost and main usage for biochemical stabilisation rather than solidification, alternatives have been investigated for strength enhancement. For instance, Kayser et al. (2011) reported on the strength improvement for biosolids 2 material ( $w=330-380 \%$ ) mixed with alkaline waste products (i.e. 30,40 and $50 \mathrm{wt} \%$ of fly ash, lime kiln dust or two smelter slags, respectively), together with 0,10 or $20 \mathrm{wt} \%$ lime. From these mixtures, the best performing additive in terms of the highest strength mobilised, and for $\mathrm{pH}>11$, was achieved for the fly ash with $20 \mathrm{wt} \%$ lime mixture. Subsequently, Kayser et al. (2015) assessed the efficacy of adding lime and lime mixed with fly ash, lime kiln dust or two smelter slags at various concentrations as potential stabilising agents for biosolids 2 material $(w=76 \cdot 7-80 \cdot 3 \%)$, while confined under pressures typically encountered in modern landfills. These alkaline additives were found to enhance strength and stiffness (fly ash and lime mixtures achieved the greatest strength increases), but produced more compressible material (i.e. larger leachate volumes and greater settlement). Maghoolpilehrood et al. (2013, 2014, 2015) reported that compacted aged biosolids 3 and 4 materials ( $w=40 \%$ and with $O W C$ for compaction values of 53 and $28 \%$, respectively) mixed with ordinary Portland cement (OPC) or lime at 3 and $5 \mathrm{wt} \%$, respectively, were suitable as embankment fill materials. Wanigaratne and Udamulla (2012) reported that when mixed with $30 \%$ crushed bricks, aged biosolids 2 material having $w=68.8 \%$ was also suitable as embankment fill. Disfani et al. (2015) reported on the chemical stabilisation of compacted aged biosolids $1(w=48-57 \%$ and with an $O W C$ for compaction value of 53\%) using 10 or $20 \mathrm{wt} \%$ Class $\mathrm{F}$ fly ash or bauxsol (red mud) at 3 or $5 \mathrm{wt} \%$, with the greater strength among the mixtures investigated achieved for the $10 \mathrm{wt} \%$ fly ash mixture. Lin et al. (2013) investigated the improvement in solidification/stabilisation for air-dried sewage sludge 4 material $(w=$ $76 \%$ ) mixed with OPC achieved using calcium bentonite (primarily montmorillonite), fly ash and kaolinite, as additives. He et al. (2015) investigated the feasibility of modifying sewage sludge 7 having $w=$ $554 \%$ for use as interim landfill cover material, with a sludge/lime/ cement/silt/tire-derived aggregate mixture (weight ratios of 100:15:5:70:15, respectively) satisfying strength and permeability requirements. It is clear from these studies that the amount of additive required depends significantly on the natural water content and TVS values of the biosolids and sewage sludge materials as well as the intended applications for the treated materials. Other determining factors include mineralogical and organic matter compositions and the amounts of drying, consolidation and (/or) biodegradation post-treatment, which are governed by the water/ wastewater source, types and levels of treatments provided at the municipal works and age of material deposited in stockpiles, pits, lagoons, monofills or sanitary landfills.

\section{Design strength for stability evaluations General considerations}

Appropriate design shear strength values for short- and long-term stability evaluations of biosolids, sewage sludge and WTR monofill 
facilities are difficult to estimate due to the complex nature of these materials and the lack of any documented design and field case histories. For instance, in considering the application of laboratory test results to design analysis for monofill stability evaluations, high strain rate dependency and the effects of wetting (dependent on the effectiveness of the surface water control system) and (or) solar drying on-site create a problematic situation in deciding which shear strength parameters and design strength values to employ. The situation is more complicated for biosolids and sewage sludge monofills because of the following.

- Because these materials are not fully saturated and, hence, not $\phi_{\mathrm{u}}=0^{\circ}$ materials ('Unsaturated condition of biosolids and sewage sludge' section), their undrained strengths are dependent on the overburden pressure.

- Ongoing biodegradation for $\mathrm{pH}<11$ alters their geotechnical properties, with the production of biogas that may or may not break free of these materials and escape to the ground surface, as well as dissimilar gas and liquid pressures (with the former unlikely to be solely a function of depth (Kayser et al., 2011)).

- Hence, the usual criteria of an 'end-of-construction' case and a long-term case may not capture the critical situation (Kayser et al., 2011).

Air-drying of the on-site materials produces significant volumetric shrinkage (e.g. ratio of reduction in bulk volume to reduction in water content was reported as 1.34 for sewage sludge 1 (O'Kelly, 2006)), such that the stability analysis of the landfill slopes must consider the effect of shrinkage cracks that may open up in the vicinity of the slope crest.

Drainage is also a critical aspect of monofill design because the provision of channels of relatively high permeability accelerates the consolidation process and promotes relatively uniform settlement, with the drainage system design based on the rate of leachate expulsion, which is governed (among other factors) by the permeability coefficient of the landfilled material. Containment measures must include means of controlling and treating the leachate and landfill gases generated, with routine monitoring of meteorological data, groundwater and surface water providing assurances that pollution control measures are working effectively.

\section{Intermediate and long-term conditions}

Stability calculations for the intermediate and long-term conditions are based on the constant volume effective friction angle $\phi_{\mathrm{cv}}^{\prime}$ (i.e. at critical state), rather than the peak effective friction angle $\phi^{\prime}$, and for a cohesion intercept $\left(c^{\prime}\right)$ value of zero. However, $\phi_{\mathrm{cv}}^{\prime}$ values have not been reported in any literature for biosolids, sewage sludge or WTR materials; rather only $\phi^{\prime}$ values, including CIUC triaxial $\phi^{\prime}$ values of $32-37^{\circ}$ (sewage sludge 1 by O'Kelly (2005d, 2006)), 32-42 (biosolids 4 by GLSEC (2003)), $33 \cdot 0-39 \cdot 6^{\circ}$ (aged biosolids 1 by Arulrajah et al. (2013)), 26.5 (aged biosolids 3 by Maghoolpilehrood et al. (2013)) and 39-44 ${ }^{\circ}$ (alum WTRs $1-3$ by O'Kelly and Quille (2010)), $\phi^{\prime}=44^{\circ}$, with $c^{\prime}=77 \mathrm{kPa}$ (alum WTR 9 by Roque and Carvalho (2006)), $\phi^{\prime}=42 \cdot 3-44 \cdot 0^{\circ}$, with $c^{\prime}=6 \cdot 9-8.3 \mathrm{kPa}$ (iron WTR 1 and alum WTRs 5 and 6 by Wang et al. (1992)) and $\phi^{\prime}=41^{\circ}$ (Wu et al., 2007). All these values are considered too high for design purposes, noting that the $c^{\prime}$ value for different types of normally consolidated sludge and residue materials is invariably negligible.

More realistic $\phi^{\prime}$ values ranging from $10^{\circ}$ to $15^{\circ}$ have been reported for sewage sludge 5 from consolidated drained direct shear testing (Zhan et al., 2014). In a forthcoming article entitled 'Shear strength of biosolids for monofill design' by Oettle, O'Kelly and Ramos, the authors deduced values of $\phi^{\prime}$ at the upper end of this range for inundated compacted biosolids 1 using consolidated undrained direct simple shear testing. In this instance, the compaction-induced cross-anisotropic fabric of the test specimens may also have some influence on the low measured $\phi^{\prime}$ values, with the direction of shear coincident with the cross-anisotropic plane. Encouragingly, the $\phi^{\prime}$ values of $\sim 17^{\circ}$ and $19^{\circ}$ predicted for biosolids 1 and sewage sludge 5 materials $(P I=$ 390 and $247 \%$, respectively) by using Equation 4 are in much better agreement with the range of $10-15^{\circ}$ determined using the direct shear and direct simple shear approaches, compared with the reported triaxial $\phi^{\prime}$ range of $32-42^{\circ}$ for biosolids 4 and sewage sludge 1 (GLSEC, 2003; O'Kelly, 2005d, 2006). Note that Equation 4 was deduced by Sorensen and Okkels (2013) from the combined data sets presented by Ladd et al. (1977), Terzaghi et al. (1996) and Brooker and Ireland (1965) for normally consolidated reconstituted and undisturbed clays.

\section{4. $\phi^{\prime}=43-10 \times \log P I$}

where $P I$ is the plasticity index.

Similar general conclusions have been reported for peat materials, with direct simple shear testing providing conservative $\phi^{\prime}$ values compared with triaxial compression (O'Kelly, 2015a). Further, according to Mesri and Ajlouni (2007), for fibrous peats having initial void ratio and effective confining pressure combinations that lead to contractive followed by dilative response during shear, $\phi_{\mathrm{cv}}^{\prime}$ is mobilised at the phase transformation point - that is, where the specimen deformation response changes from contractive to dilative behaviour. Using this approach, the value of $\phi_{\mathrm{cv}}^{\prime}$ can be determined for a given biosolids, sewage sludge or WTR material from the analysis of ideally three or more effective stress path plots. Note that the values of engineering properties used in stability analysis must be consistent with the actual/envisaged bioactivity and degree of biodegradation of the on-site material.

\section{Case study: As-Samra WWTP monofill facility}

In a forthcoming article entitled 'Shear strength of biosolids for monofill design' by Oettle, O'Kelly and Ramos, the authors adopted the observational method (after Peck (1969)) in designing the As-Samra WWTP monofill facility (proposed compacted biosolids monofill having a final fill height of $\sim 30 \mathrm{~m}$ and slope 
gradients of six horizontal and one vertical), towards overcoming design uncertainties described in 'General considerations' section. Using the observational method, the design envisaged compacting the biosolids material at $\sim 100 \%$ water content and was based on the higher end of the laboratory undrained strength range (43 $\mathrm{kPa}$ in UU triaxial compression) mobilised for this water content value, adopting an $F$ value against the slope instability of $1 \cdot 5$. The $100 \%$ water content value was adopted instead of the material's $O W C$ for standard Proctor compaction of $83 \%$ to mitigate against strength reductions arising from swelling on account of compactioninduced overconsolidation. In implementing the observational approach, extensive ground instrumentation and monitoring were designed to alert the monofill operator of impending instability issues, should the assumed shear strength not be achievable onsite, and allow for necessary corrective action to occur in a timely manner. As described by the authors, extensive biogas extraction, leachate drainage and surface water control systems were proposed, with the surface water control system designed to limit rainwater infiltration of the monofill body, thereby mitigating against wetting of the compacted biosolids material and, hence, reductions in its as-compacted shear strength.

\section{Strength predictions}

In practice, the strength testing of the sludge and residue materials can be time consuming and resource intensive compared with water content determinations, for which multiple measurements can be quickly obtained in field and (/or) laboratory settings using portable instruments that employ various radiological techniques (e.g. neutron scattering and gamma absorption) or rely on the soil's dielectric properties (e.g. using time-domain reflectometry) (IAEA, 2008). Note that the determination of the gravimetric water content from these volumetric water content measurements requires careful calibration for the specific soil under investigation. The challenge, however, is to accurately relate undrained strength with measured water content, with the relative merits of different approaches described in this section.

\section{Non-uniqueness of undrained strength-water content relationship}

For a given water content, the remoulded undrained strength mobilised is dependent on the soil grading, composition and mineralogy (in particular of the clay fraction), physical state (compaction level and degree of saturation) and the strength measurement method employed. For the latter, the determining factors include the test specimen size, stress and boundary conditions and shearing rate and mode (see 'Strength measurement' section). Hence, as discussed by O'Kelly (2013c), no universal relationship (correlation) exists between undrained strength and water content for geomaterials. Further, other influencing factors for biosolids, sewage sludge and WTR materials include

natural variability in the composition of the suspended solids in the raw (source) waters over time, which affects the mineralogical composition and organic matter content of the sludge/residue produced at the treatment plant
- treatment processes employed, including chemical additives and dosages (depend on source water quality and vary according to its temperature and $\mathrm{pH}$ ) used at the treatment plant to separate out the sludge/residue by-product

- level of bioactivity for biosolids and sewage sludge materials (O’Kelly, 2013b, 2013c).

\section{Undrained strength correlations WITH WATER CONTENT}

As evident from Figure 11(a), remoulded undrained strength-water content correlations for biosolids/sewage sludge and WTR materials are highly non-linear and generally cannot be applied with confidence to other for biosolids/sewage sludge or WTR materials, even for those of the same soil classification. Further, it has been well documented that, compared with the much-reduced concave curvatures of logarithm undrained strength against water content relationships (Figure 11(b)), such relationships are nearly linear when presented on a bilogarithmic plot (Koumoto and Houlsby, 2001; Sharma and Bora, 2003), especially for soils having wide water content ranges under investigation and also for organic soils (O'Kelly 2014a, 2016b; Zentar et al. 2009). For instance, referring to Table 2, the bi-logarithmic data plots for the sewage sludge 1 and alum WTR 1-6 materials in Figure 11(c) generally gave higher coefficient of determination $\left(R^{2}\right)$ values compared with the semilogarithmic plots of the same data in Figure 11(b). The justification for using the bilogarithmic approach, within the critical state soil mechanics framework, is given by Butterfield (1979).

\section{WITH LIQUIDITY INDEX}

Where $L L$ and $P L$ data are available, the liquidity index is often preferred over water content for correlations with strength. Although usually quite sharp for a given material, undrained strength-liquidity index correlations can also vary widely between geomaterials since the strengths mobilised at the Casagrande $L L$ and $P L$ states are not unique (Haigh et al., 2013; Nagaraj et al., 2012; O’Kelly, 2013c). This is compounded by general difficulties in measuring and interpreting consistency limit values for organic soils (O'Kelly, 2013a, 2013b, 2014a, 2016b, 2016e; O'Kelly and Zhang, 2013). For instance, in testing alum WTR 4, O'Kelly (2014a) observed that the bulk material could be easily remoulded by hand pressure at water contents significantly below the $P L$ measured using the standard thread rolling method (BSI, 1990a), indicating that its value did not represent the lower limit of plasticity. Similar findings were reported for blended and sieved peat materials having $L L=757 \%$ and $P L=$ $446 \%$ (O'Kelly and Zhang, 2013) and $L L=762 \%$ and $P L=446 \%$ (O'Kelly, 2015b). These findings cast doubt on the usefulness of measured and reported plastic limits in defining the lower water content limit for remoulding of these materials in practice. In practice, therefore, the liquidity index is an unreliable indicator of soil consistency, especially for organic soil and in particular fibrous organic soil (O'Kelly, 2014b).

\section{WITH BULK DENSITY}

Building on the experimental work of Voß (1993), Klein and Sarsby (2000) and Sarsby (2005) reported that bulk density appeared to be a 


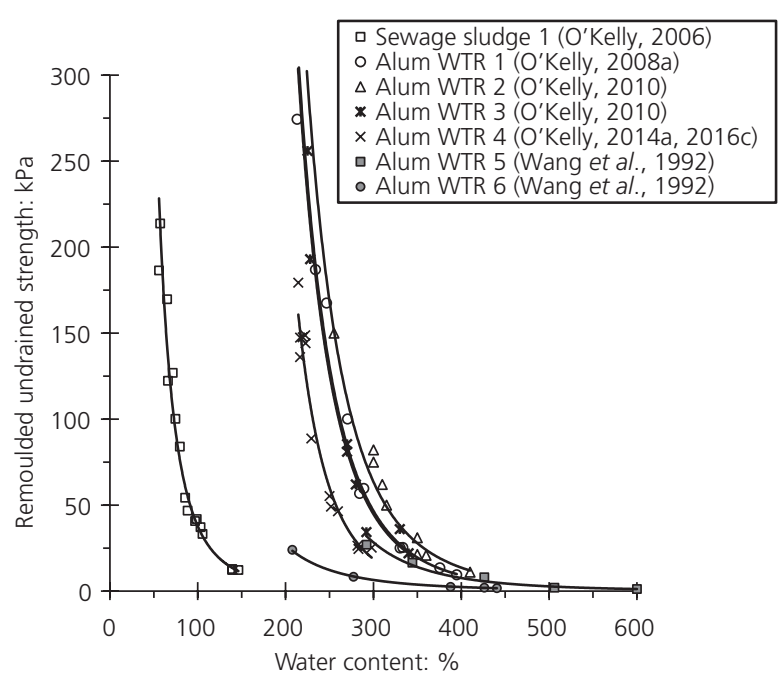

(a)

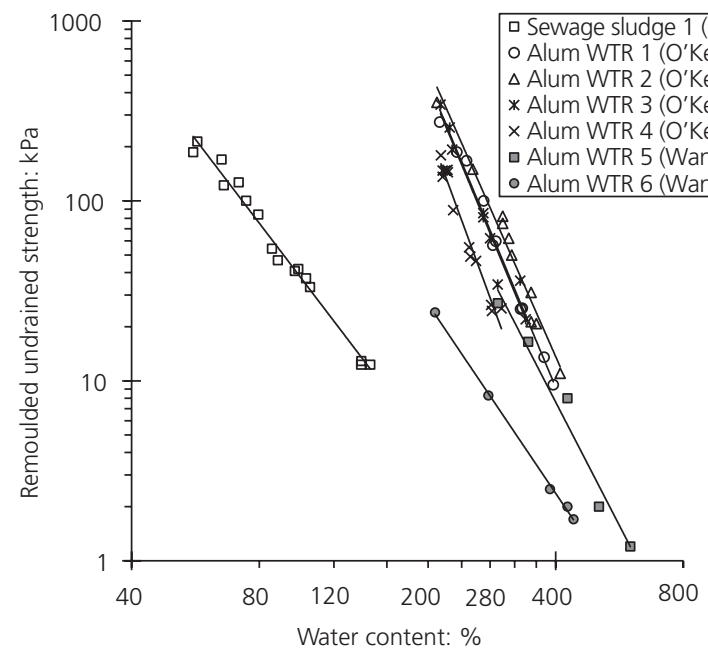

(c)

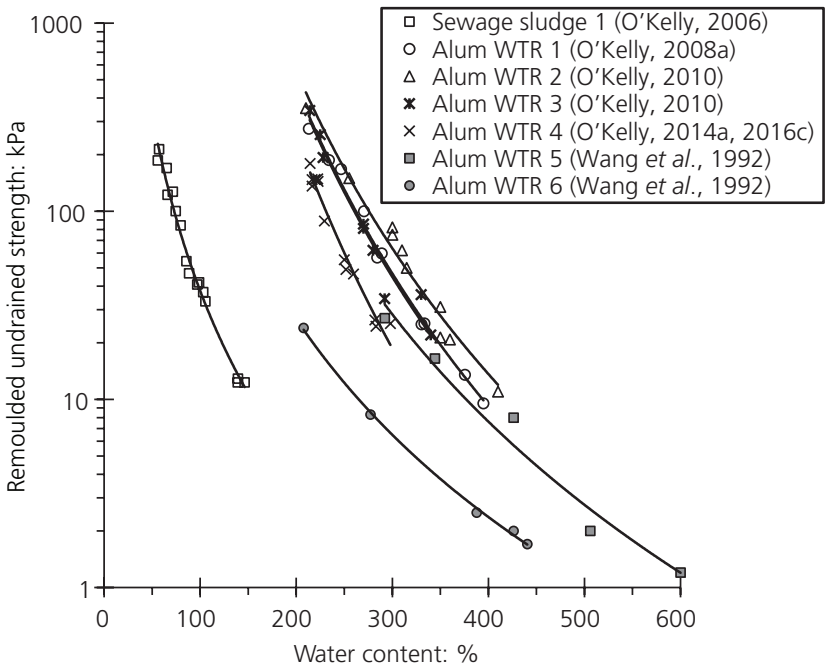

(b)

Figure 11. Undrained strength against water content correlations for municipal sludge and residue materials: (a) bilinear axes,

(b) semi-logarithmic plot and (c) bilogarithmic plots

better indicator than water content of the shear strength for soft sewage sludge since it encompasses the effects of both water content (void ratio) and fibre content, although they noted that the fibres in sewage sludge provide little frictional shear resistance at very high water content. Voß (1993) had presented an empirical relationship (Equation 5) between on-site vane shear strength $\left(s_{\mathrm{u}_{\text {vane }}}\right.$, in kilopascal) and bulk density ( $\rho$, in megagrams per cubic metre) for monofilled sewage sludge, which predicts strengths in the general range of $1-60 \mathrm{kPa}$ as bulk density increases from $1 \cdot 0$ to $1 \cdot 25 \mathrm{Mg} / \mathrm{m}^{3}$.

5. $s_{\mathrm{u}_{\text {vane }}}=2.09 \times 10^{-8} \mathrm{e}^{17.5 \rho}$

From their experimental work, Klein and Sarsby (2000) and Sarsby (2005) reported that Equation 5 gave a reasonable representation of laboratory vane strength data they obtained for fresh very soft to soft sewage sludge material, concluding that bulk density appeared to be a better indicator of the shear strength for soft sewage sludge. However, using laboratory vane strength data reported by O'Kelly (2006) for sewage sludge 1, the author has found that apart from $s_{\mathrm{u}_{\mathrm{v}} \text { of }}<7 \mathrm{kPa}$, Equation 5 does not give a reasonable representation of the experimental strength data, significantly underpredicting mobilised strength values for this sewage sludge material (see Figure 12). This further demonstrates that undrained strength-water content correlations derived for particular biosolids, sewage sludge or WTR materials cannot be applied with confidence to other materials for the reasons described in 'Non-uniqueness of undrained strength-water content relationship' section.

\section{Existing undrained strength-water content relationships}

Various relationships have been proposed for estimating the remoulded undrained shear strength from measured values of water 
Sewage sludge 1

Alum WTR 1

Alum WTR 2

Alum WTR 3

Alum WTR 4

Alum WTR 5

Alum WTR 6
0.9726
0.9889
0.9825
0.9378
0.9597
0.9751
0.9865

0.9855

0.9909

0.9721

0.9559

0.9698

0.9691

0.9986

Table 2. Analyses of semi-logarithmic and bilogarithmic correlations for various sewage sludge and WTR materials

content, with such relationships often incorporating measured $L L$ and $P L$ values in the calculations, with the main ones reviewed by O'Kelly (2013c). Many of them assume a 100-fold strength variation between the water content values corresponding to the $L L$ and $P L$ conditions, but as O'Kelly (2013c) emphasised, there is no theoretical basis for this, with the ratio of the strengths mobilised at the $P L$ and $L L$ conditions varying over a wide range when many different soils are considered (Haigh et al., 2013; Nagaraj et al., 2012; O'Kelly, 2013c, 2015b). This is particularly true for organic soils, including the municipal water/wastewater sludge and residue materials under consideration in this paper, for which the ratio of the strengths mobilised at the $P L$ and $L L$ has been found to be significantly less than 100 (O'Kelly, 2013c, 2014a, 2014b, 2015b, 2016b; Zentar et al., 2009). For example, using consistency limit and vane strength data reported by Zentar et al. (2009) for four marine sediments (TVS $=6 \cdot 7-9 \cdot 7 \%$ ), O'Kelly (2013c) deduced a 10-27-fold strength increase over the measured plastic ranges for these materials.

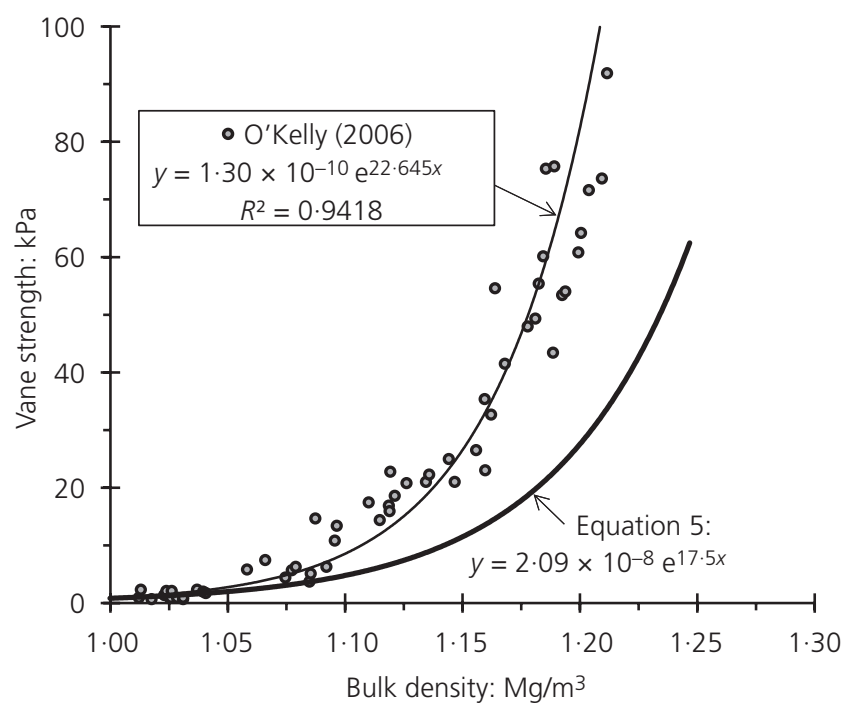

Figure 12. Measured and deduced strength-bulk density correlations for sewage sludge 1
Hence, when applied to organic soils, such correlations (i.e. based on an assumed 100-fold strength variation over the plastic range) produce significant overestimations of undrained shear strength.

\section{New approach to undrained strength prediction from measured water content}

A new approach to predicting remoulded undrained strengths mobilised for different water contents, which uses a power-law relationship, was proposed by O'Kelly (2013c). This approach does not rely on empirical strength values associated with the $L L$ and $P L$, nor does it rely on the fallacy of an assumed (fixed) value for the strength variation over the plastic range ('Existing undrained strength-water content relationships' section). In applying the method, the control data are obtained for the specific soil material under investigation from strength measurements for two test specimens prepared at different water contents within the plastic range (i.e. $P L<w_{2}<w_{1}<L L$ ), but ideally for water contents close to the $L L$ and $P L$, so as to cover a wider water content range. From these strength and corresponding water content measurements for the two test specimens, the remoulded undrained strength value corresponding to any value of water content $\left(w_{\mathrm{n}}\right)$ within the plastic range can be deduced for this particular soil material, as

6. $\log s_{\mathrm{ur}}=\left(1-W_{\mathrm{LN}}\right)\left(\log \frac{s_{\mathrm{ur} 2}}{s_{\mathrm{ur} 1}}\right)+\log s_{\mathrm{ur} 1}$

where $s_{\text {ur1 }}$ and $s_{\text {ur2 }}$ are measured remoulded undrained strengths (with corresponding water contents of $w_{1}$ and $w_{2}$ ) and $W_{\mathrm{LN}}$ is a relative water content parameter given by Equation 7, noting that $W_{\mathrm{LN}}$ is not tied to any standard test or procedure

7. $W_{\mathrm{LN}}=\frac{\log w_{\mathrm{n}}-\log w_{2}}{\log w_{1}-\log w_{2}}$

Full details on the development of this approach and its application in determining the remoulded undrained strength of different geomaterials are presented in the papers by O'Kelly (2013c, 2016b). 


\section{Effect of oven-drying temperature on undrained strength-water content correlation}

As described in the 'Water content determinations' section, the oven temperature value used for water content determinations by the standard oven-drying method can significantly affect the measured water content value, and as demonstrated in Figure 13, this has a knock-on effect in translating the undrained strength-water content correlation, especially for high water content materials. For routine water content determinations on organic soils, standardised oven-drying temperature ranges of $110 \pm 5^{\circ} \mathrm{C}$ (ASTM, 2014) or $105-110^{\circ} \mathrm{C}$ (BSI, 1990a) specified for the testing of inorganic soils should be consistently used (Hobbs, 1986; O'Kelly, 2014b; O'Kelly and Sivakumar, 2014; Skempton and Petley, 1970) in conjunction with a 24-h drying period and minimum wet specimen mass of $50 \mathrm{~g}$ (O'Kelly and Sivakumar, 2014).

Oven-drying temperatures in the range of $60-90^{\circ} \mathrm{C}$ are still used in some commercial and research laboratories, in which case, it is recommended that values of water content corresponding to the pertinent standardised oven-drying temperature range be deduced from these measured water content values. For this purpose, methods presented by Skempton and Petley (1970) and O'Kelly (2005e) to relate water content values determined for the same material but on the basis of different oven-drying temperatures can be used. Further, as recommended by O'Kelly (2014b), where correlations with water content are used to assess strength, an oven temperature value should also be specified with the required minimum strength value in cases where water content is determined using the oven-drying method. For instance, a shear strength of $10 \mathrm{kPa}$ would be mobilised for alum WTR 4 at water contents of 303, 329 and 336\% (Figure 13), basis on oven-drying

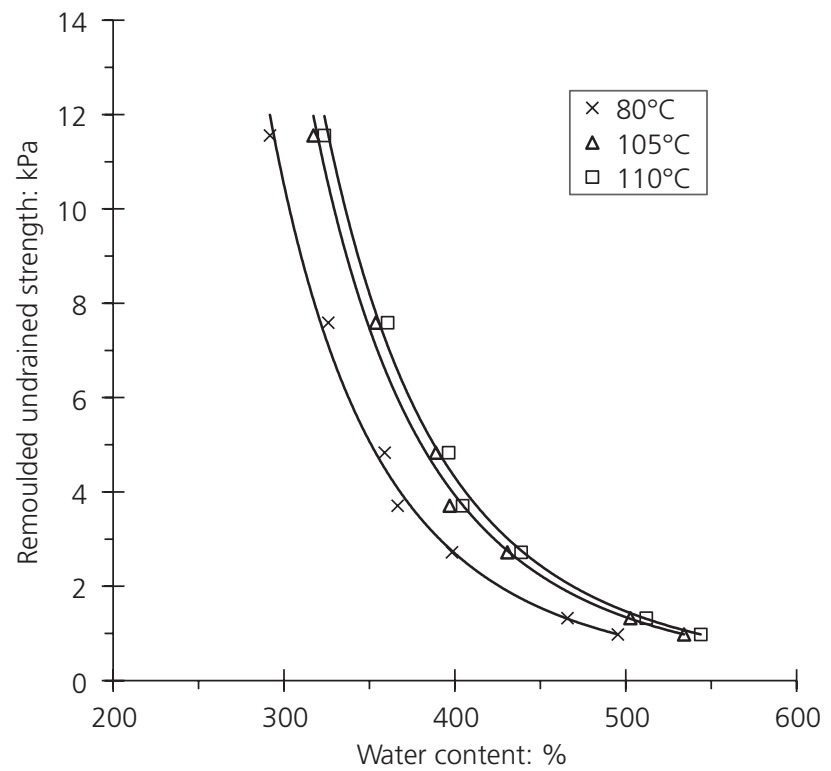

Figure 13. Undrained strength correlations for alum WTR 4 demonstrating the effect of different oven-drying temperatures for water content determinations (adopted from O'Kelly (2014b)) temperatures of 80,105 and $110^{\circ} \mathrm{C}$, respectively. In other words, strength assessment and verification procedures for landfilling should consistently use the same combination of minimum strength requirement and oven-drying temperature values in applying correlations. In practice, as the example mentioned demonstrates, the error resulting from the use of an oven-drying temperature value below the standard ranges would result in higher mobilised strength (conservative design), although on the downside, it would require unnecessarily higher levels of dewatering to meet specified minimum strength requirements.

\section{Summary and conclusions}

Dewatered biosolids, sewage sludge and WTR materials are manufactured fine-grained soils, having extremely high water content and plasticity, high to very high organic matter content, low specific gravity of solids and low bulk and dry densities. Further, these materials typically exhibit low shear strength, poor compaction behaviour, very high compression, swelling and shrinkage potentials and have very to extremely low permeability. The mineralogical and organic matter compositions of these challenging and unconventional geomaterials are determined by the water/wastewater source from which they were generated, types and extent of treatment processes employed, amounts of ions, suspended solids and colloidal materials removed and the types of chemicals added, with all these factors influencing their geotechnical behaviour/properties. In general, wet biosolids and sewage sludge materials are classified as organic clay of extremely high plasticity, WTR materials as organic silt of extremely high plasticity and lime-softening sludge as silt of low to intermediate plasticity.

The behaviour of these dewatered sludge and residue materials in lagoons, monofills and sanitary landfills can be assessed with reasonable accuracy using soil mechanics theory and conventional on-site and geotechnical laboratory testing, provided due care and attention are given to their distinctive properties, in particular the high strain rate dependence of strength; and for biosolids and sewage sludge, the viscous gel-like pore fluid and the fact that they do not behave as $\phi_{\mathrm{u}}=0^{\circ}$ materials.

Biosolids and sewage sludge materials are arguably more problematic geotechnically than WTR materials since they generally have higher organic matter content and a propensity to degrade and produce biogas, such that their compositions and, hence, engineering behaviour/properties can change significantly over time. Permanent material change also arises from the oxidation of the dry sludge material in beds and stockpiles, with the transformation producing a change in material behaviour from that of organic clay of extremely high plasticity to organic silt of high to extremely high plasticity. Available information suggests that greater levels of biodegradation for biosolids and sewage sludge materials are associated with reductions in plasticity and organic content (the latter correlating with reductions in natural water content); an increase in specific gravity and, hence, bulk and dry densities; a reduction in the $O W C$ for compaction and an 
increase in the maximum dry density achieved; increases in the relative proportion and rate of primary consolidation; reductions in secondary compression and biodegradation-induced settlements; and tentative increases in the permeability coefficient and effective friction angle, although for landfilled material the changes in engineering properties may not occur uniformly throughout the sludge body. Significant knowledge gaps exist, meriting experimental and theoretical investigations on the relative changes in geotechnical behaviour/properties resulting from different treatment processes and (/or) retention periods at water treatment plants/WWTPs as well as for extended periods under different environmental conditions experienced at monofills and co-disposal sanitary landfills. Long-term studies of field situations, including measurements of biogas and leachate generation, on-site water content, organic matter content, density, strength and permeability coefficient profiles with depth and compression and consolidation rates, are recommended for greater understanding of the behaviour of these materials in the landfill environment. Such studies are likely to provide the critical link in determining appropriate geotechnical parameter values for analysis and design - for instance, how to relate strength measurements from element tests in the geotechnical laboratory to the field scenario, selection of design values for shear strength and how biogas production, time-dependent properties, creep, and so on should play a role in their selection.

For strength evaluations of these sludge and residue materials for landfilling, the fall cone and miniature, handheld and on-site shear vane apparatuses are particularly attractive to operators of municipal plants and landfills, despite various shortcomings of these tests, with the author recommending the $60^{\circ}$ cone over the $30^{\circ}$ cone for fall cone strength determinations on these materials. Specimen preparation for laboratory fall cone and miniature shear vane tests requires the removal of coarse fibres (present in the test soil) that would otherwise interfere with the shearing mechanism, resulting in unconservative strength measurements. Considering the effects of differences in the size and drainage conditions of the test specimens, shearing modes, confinement pressure and strain rate, it is important to calibrate the fall cone data against shear vane or preferably against triaxial compression strength measurements, since the effects of different confinement pressure and drainage conditions can be systematically studied using the triaxial apparatus.

For undrained biosolids and sewage sludge materials, evolving biogas trapped internally reduces the degree of saturation and increases the pore fluid pressure, causing reductions in the effective confinement (overburden) pressure, consolidation rate and strength over time, which if left unchecked, can lead to excessive differential settlements and potential structural instability problems in the landfill environment. Wetting of compacted material can result in significant swelling (arising from the compaction-induced overconsolidation state) and, hence, strength reductions. Reported triaxial peak effective friction angle values for biosolids, sewage sludge and WTR materials are generally far too high for design purposes. In any case, stability calculations are typically based on the critical state effective friction angle $\phi_{\mathrm{cv}}^{\prime}$, values of which have not been reported anywhere in the literature for these materials. Direct simple shear testing would appear to provide more realistic values for design than triaxial testing. Many of the reported studies on the geotechnical behaviour/properties of these materials provide little or no information regarding the source water/wastewater characteristics and the types and extent of treatment processes employed at the different plants. Future studies should report such information in sufficient detail and will add significant value in assisting with the interpretation and understanding of measured geotechnical data.

As generally accepted, correlations between remoulded undrained strength and water content, liquidity index and bulk density are soil specific and usually cannot be applied with confidence to other materials. Hence, a new approach using a power-law relationship was presented in this paper for predicting remoulded undrained strengths mobilised for different water contents (recommended standardisation for oven-drying temperature of $105-110^{\circ} \mathrm{C}$ ), with this relationship calibrated to the test soil using two or more strength measurements at different known water contents.

\section{REFERENCES}

Arulrajah A, Disfani MM, Suthagaran V and Imteaz M (2011)

Select chemical and engineering properties of wastewater biosolids. Waste Management 31(12): 2522-2526, http://dx. doi.org/10.1016/j.wasman.2011.07.014.

Arulrajah A, Disfani MM, Suthagaran V and Bo MW (2013) Laboratory evaluation of the geotechnical characteristics of wastewater biosolids in road embankments. Journal of Materials in Civil Engineering 25(11): 1682-1691, http://dx. doi.org/10.1061/(ASCE)MT.1943-5533.0000739.

ASTM (2014) D 2974-14: Standard test methods for moisture, ash, and organic matter of peat and other organic soils. ASTM International, West Conshohocken, PA, USA.

Aydilek AH, Edil TB and Fox PJ (2000) Consolidation characteristics of wastewater sludge. In Geotechnics of High Water Content Materials (Edil TB and Fox PJ (eds)). ASTM, West Conshohocken, PA, USA, Special Technical Publication no. 1374, pp. 309-323, http://dx.doi.org/10.1520/STP14376S.

Babatunde AO and Zhao YQ (2007) Constructive approaches toward water treatment works sludge management: an international review of beneficial reuses. Critical Reviews in Environmental Science and Technology 37(2): 129-164, http:// dx.doi.org/10.1080/10643380600776239.

Basim SC (1999) Physical and Geotechnical Characterization of Water Treatment Plant Residuals. PhD thesis, New Jersey Institute of Technology, Newark, NJ, USA. See http://archives. njit.edu/vol01/etd/1990s/1999/njit-etd1999-045/njit-etd1999045.pdf (accessed 08/11/2016).

Bednarik V, Vondruska M, Sild M and Koutny M (2004) Stabilization/solidification of wastewater treatment sludge. 
Journal of Environmental Engineering 130(12): 1527-1533, http://dx.doi.org/10.1061/(ASCE)0733-9372(2004)130:12(1527).

Brooker EW and Ireland HO (1965) Earth pressures at rest related to stress history. Canadian Geotechnical Journal 2(1): 1-15, http://dx.doi.org/ 10.1139/t65-001.

BSI (1990a) BS EN 1377-2:1990: Methods of test for soils for civil engineering purposes (classification tests). BSI, London, UK.

BSI (1990b) BS EN 1377-3:1990: Methods of test for soils for civil engineering purposes (chemical and electro-chemical tests). BSI, London, UK.

BSI (1990c) BS EN 1377-4:1990: Methods of test for soils for civil engineering purposes (compaction-related tests). BSI, London, UK.

BSI (1990d) BS EN 1377-9:1990: Methods of test for soils for civil engineering purposes (in-situ tests). BSI, London, UK

BSI (2015) BS 5930:2015: Code of practice for ground investigations. BSI, London, UK.

Butterfield R (1979) A natural compression law for soils (an advance on $e-\log p^{\prime}$ ). Géotechnique 29(4): 469-480, http://dx. doi.org/10.1680/geot.1979.29.4.469.

Cao YH, Yan SW and Yang CM (2006) Test on methods to solidify wastewater sludge. Journal of Tianjin University (Science and Technology) 39(2): 199-203.

Chakma S and Mathur S (2007) Settlement of MSW landfills due to biodegradation. In Proceedings of the International Conference on Sustainable Solid Waste Management, Chennai, India (Kurian J, Nagendran R and Thanasekaran K (eds)). Centre for Environmental Studies, Anna University, Chennai, India, pp. 234-238.

Chen P, Zhan L and Wilson W (2014) Experimental investigation on shear strength and permeability of a deeply dewatered sewage sludge for use in landfill covers. Environmental Earth Sciences 71(10): 4593-4602, http://dx.doi.org/10.1007/s12665013-2851-8.

Chiang KY, Chou PH, Hua CR, Chien KL and Cheeseman C (2009) Lightweight bricks manufactured from water treatment sludge and rice husks. Hazardous Materials 171(1-3): 76-82, http:// dx.doi.org/10.1016/j.jhazmat.2009.05.144.

Claydon JR, Eadie HS and Harding C (1997) Deighton tip failure, investigation and remedial works. In Proceedings of the 19th Congress of the International Commission on Large Dams (ICOLD), Florence, Italy. ICOLD Press, Paris, France, vol. 4, pp. 233-245.

Diliūnas J, Dundulis K, Gadeikis S, Jurevičius A and Kaminskas M (2010) Geotechnical and hydrochemical properties of sewage sludge. Bulletin of Engineering Geology and the Environment 69(4): 575-582, http://dx.doi.org/10.1007/s10064-010-0279-x.

Disfani MM, Arulrajah A, Suthagaran V and Bo MW (2013) Long-term settlement prediction for wastewater biosolids in road embankments. Resources, Conservation and Recycling 77(2013): 69-77, http://dx.doi.org/10.1016/j.resconrec.2013. 05.009 .

Disfani MM, Arulrajah A, Maghoolpilehrood F, Bo MW and Narsilio GA (2015) Geotechnical characteristics of stabilised aged biosolids. Environmental Geotechnics 2(5): 269-279, http://dx.doi.org/10.1680/envgeo.13.00054

EA (Environment Agency (UK)) (2010) Waste Acceptance at Landfills. Environment Agency, Bristol, UK. See https://www. gov.uk/government/uploads/system/uploads/attachment_data/ file/296422/geho1110btew-e-e.pdf (accessed 25/07/2016).

EC (European Community) (1999) Directive 1999/31/EC of the European Parliament and of the Council of 26 April 1999 on the Landfill of Waste. Official Journal of the European Communities $\mathbf{L 1 8 2}$.

EC (2006) Directive 2006/12/EC of the European Parliament and of the Council of 5 April 2006 on Waste. Official Journal of the European Communities L114.

Elliott HA, Dempsey BA, Hamilton DW and DeWolfe JR (1990) Land Application of Water Treatment Sludges: Impacts and Management. American Water Works Association Research Foundation and American Water Works Association, Denver, $\mathrm{CO}$, USA

Fei X, Zekkos D, Li L, Woods R and Sanford L (2016) Geocharacterisation of lime water treatment sludge. Environmental Geotechnics, http://dx.doi.org/10.1680/jenge.15.00028.

Geonor (2015) Data Sheet on GEONOR Fall Cone Apparatus. Geonor, Eiksmarka, Norway. See http:/geonor.com/datasheets/ Geonor_Fall_Cone_Apparatus.pdf (accessed 18/05/2016).

Geuzens P and Dieltjens W (1991a) Mechanical strength determination of cohesive sludges - a Belgian research project on sludge consistency. In Proceedings of a Workshop on Recent Developments in Sewage Sludge Processing, Lappeenranta, Finland (Colin F, Newman PJ and Puolanne YJ (eds)). Elsevier, London, UK, pp. 14-23.

Geuzens P and Dieltjens W (1991b) Presentation of a research project on sludge consistency. In Proceedings of a Symposium on Treatment and Use of Sewage Sludge and Liquid Agricultural Wastes, Athens, Greece, 1st-4th October 1990 (L'Hermite P (ed.)). Elsevier, London, UK, pp. 381-387.

GLSEC (Great Lakes Soil \& Environmental Consultants, Inc.) (2003) Geotechnical Characterization of Biosolids. Research and Development Department, Metropolitan Water Reclamation District of Greater Chicago, Chicago, IL, USA, Report No. 03-8. See https://www.mwrd.org/pv_obj_cache/ pv_obj_id_1F658A5ED4CB07BDB0A0104D97A71D 7D95E14B00/filname/03-8_Geotechnical_Charact erization_of_Biosolids.pdf (accessed 08/11/2016).

Haigh SK, Vardanega PJ and Bolton MD (2013) The plastic limit of clays. Géotechnique 63(6): 435-440, http://dx.doi.org/10. 1680/geot.11.P.123.

Hansbo S (1957) A new approach to the determination of the shear strength of clay by the fall cone test. Proceedings of the Royal Swedish Geotechnical Institute 14: 1-48.

Haynes RJ, Murtaza G and Naidu R (2009) Inorganic and organic constituents and contaminants of biosolids: implications for land application. In Advances in Agronomy (Sparks DL (ed.)). Academic Press, Burlington, MA, USA, vol. 104, pp. 165-267, http://dx.doi.org/10.1016/S0065-2113(09) 04004-8. 
Geotechnics of municipal sludges and

residues for landfilling

O'Kelly
Hazell E (2008) Numerical and Experimental Studies of Shallow Cone Penetration in Clay. PhD thesis, University of Oxford, Oxford, UK. See http://www.eng.ox.ac.uk/civil/publications/ theses/hazell.pdf (accessed 08/11/2016).

He J, Li F, Li Y and Cui XL (2015) Modified sewage sludge as temporary landfill cover material. Water Science and Engineering 8(3): 257-262, http://dx.doi.org/10.1016/j.wse.2015.03.003.

Hobbs NB (1986) Mire morphology and the properties and behaviour of some British and foreign peats. Quarterly Journal of Engineering Geology 19(1): 7-80, http://dx.doi.org/ 10.1144/GSL.QJEG.1986.019.01.02.

Horn A (1990) Erfahrung mit einer monodeponie für kalkstabilisierten klärschlamm. In Geotechnische Probleme beim Bau von Abfalldeponien (Gartung E (ed.)). Grundbauinstitutes Landesgewerbeanstalt Bayern, Nürnberg, Germany, vol. 56, pp. 163-177 (in German).

IAEA (International Atomic Energy Agency) (2008) Field Estimation of Soil Water Content: a Practical Guide to Methods, Instrumentation and Sensor Technology. IAEA, Vienna, Austria, Training Course Series No. 30. See http:// www-pub.iaea.org/mtcd/publications/pdf/tcs-30_web.pdf (accessed 25/07/2016).

Ippolito JA, Barbarick KA and Elliott HA (2011) Drinking water treatment residuals: a review of recent uses. Environmental Quality 40(1): 1-12, http://dx.doi.org/10.2134/jeq2010.0242.

Kayser C (2012) The Geotechnical and Environmental Properties of Amended Biosolids. PhD thesis, University of Auckland, Auckland, New Zealand. See http://hdl.handle.net/2292/18902 (accessed 08/11/2016).

Kayser C, Larkin T and Singhal N (2011) Enhancement of the shear strength of wastewater residuals using industrial waste by-products. Journal of Environmental Engineering 137(11): 1002-1011, http://dx.doi.org/10.1061/(ASCE)EE.1943-7870. 0000426.

Kayser C, Larkin T and Singhal N (2015) Amendment of biosolids with waste materials and lime: effect on geoenvironmental properties and leachate production. Waste Management 46: 165-175, http://dx.doi.org/10.1016/j.wasman.2015.08.024.

Kim EH, Cho JK and Yim S (2005) Digested sewage sludge solidification by converter slag for landfill cover. Chemosphere 59(3): 387-395, http://dx.doi.org/10.1016/j.chemosphere.2004. 10.038 .

Klein A and Sarsby RW (2000) Problems in defining the geotechnical behaviour of wastewater sludges. In Geotechnics of High Water Content Materials (Edil TB and Fox PJ (eds)). ASTM, West Conshohocken, PA, USA, Special Technical Publication no. 1374, pp. 74-87, http://dx.doi.org/10.1520/STP14360S.

Koenig A and Bari QH (2001) Vane shear strength of dewatered sludge from Hong Kong. Water Science and Technology 44(2-3): 389-397.

Koenig A and Kay JN (1994) A mathematical model for the prediction of vane shear strength in dewatered sewage sludges. Proceedings of the International Conference on Computational Methods in Structural and Geotechnical Engineering, Hong Kong, pp. 1596-1601.
Koenig A and Kay JN (1995) Geotechnical stability of dewatered wastewater sludges for landfills. Proceedings of the 68th Annual Conference of the Water Environment Federation, Miami Beach, FL, USA, pp. 213-223.

Koenig A, Kay JN and Wan IM (1996) Physical properties of dewatered wastewater sludge for landfilling. Water Science and Technology 34(3-4): 533-540, http://dx.doi.org/10.1016/ 0273-1223(96)00621-X.

Komlos J, Welker A, Punzi V and Traver R (2013) Feasibility study of as-received and modified (dried/baked) water treatment plant residuals for use in storm-water control measures. Journal of Environmental Engineering 139(10): 1237-1245, http://dx.doi.org/10.1061/(ASCE)EE.1943-7870. 0000737 .

Kondner RL (1963) Hyperbolic stress-strain response: cohesive soils. Journal of the Soil Mechanics and Foundations Division, ASCE 89(1): 115-144.

Koumoto T and Houlsby GT (2001) Theory and practice of the fall cone test. Géotechnique 51(8): 701-712, http://dx.doi.org/ 10.1680/geot.2001.51.8.701.

Kulhawy FH and Mayne PW (1990) Manual on Estimating Soil Properties for Foundation Design. Electric Power Research Institute, Palo Alto, CA, USA, Report No. EL-6800. See http://www.epri.com/abstracts/Pages/ProductAbstract.aspx? ProductId=el-6800\&Mode=download (accessed 08/11/2016).

Kyambadde BS and Stone KJL (2012) Index and strength properties of clay-gravel mixtures. Proceedings of the Institution of Civil Engineers - Geotechnical Engineering 165(1): 13-21, http://dx.doi.org/10.1680/geng.2012.165.1.13.

Ladd CC and Foott R (1974) New design procedure for stability of soft clays. Journal of Geotechnical Engineering Division, ASCE 100(7): 763-786.

Ladd CC, Foott R, Ishihara K, Schlosser F and Poulos HG (1977) Stress-deformation and strength characteristics: state-of-the-art report. In Proceedings of the 9th International Conference on Soil Mechanics and Foundation Engineering, Tokyo, Japan. Balkema, Rotterdam, the Netherlands, vol. 2, pp. 421-494.

Landva AO (1980a) Geotechnical Behaviour and Testing of Peat. $\mathrm{PhD}$ thesis, Laval University, Quebec City, QC, Canada.

Landva AO (1980b) Vane testing in peat. Canadian Geotechnical Journal 17(1): 1-19, http://dx.doi.org/10.1139/t80-001.

Lee J (2010) Shear Strength Enhancement of Biosolids Using Industrial By-products. Master's thesis, University of Auckland, Auckland, New Zealand.

Lim S, Jeon W, Lee J, Lee K and Kim N (2002) Engineering properties of water/wastewater-treatment sludge modified by hydrated lime, fly ash and loess. Water Research 36(17): 4177-4184, http://dx.doi.org/10.1016/S0043-1354(02)00150-1.

Lin C, Zhu W and Han J (2013) Strength and leachability of solidified sewage sludge with different additives. Journal of Materials in Civil Engineering 25(11): 1594-1601, http://dx. doi.org/10.1061/(ASCE)MT.1943-5533.0000738.

Lin W, Zhan X, Zhan TL et al. (2014) Effect of $\mathrm{FeCl}_{3}$-conditioning on consolidation property of sewage sludge and vacuum preloading test with integrated PVDs at the Changan landfill, 
China. Geotextiles and Geomembranes 42(3): 181-190, http://dx.doi.org/10.1016/j.geotexmem.2013.12.008.

Lo IMC, Zhou WW and Lee KM (2002) Geotechnical characterization of dewatered sewage sludge for landfill disposal. Canadian Geotechnical Journal 39(5): 1139-1149, http://dx.doi.org/10.1139/t02-058.

Loll U (1986) Characterization of the physical nature of sewage sludge with particular regard to its suitability as landfill. In Proceedings of the 4th International Symposium on Processing and Use of Organic Sludge and Liquid Agricultural Wastes, Rome, Italy, 8-11th October 1985 (L'Hermite P (ed.)). D. Reidel, Dordrecht, the Netherlands, pp. $168-177$.

Loll U (1991) Measurement of laboratory vane shear strength as Community standard or reference method for testing the suitability of de-watered sludges for use as landfill. In Proceedings of a Symposium on Treatment and Use of Sewage Sludge and Liquid Agricultural Wastes, Athens, Greece, 1st-4th October 1990 (L'Hermite P (ed.)). Elsevier, London, UK, pp. 310-315.

Long M (2005) Review of peat strength, peat characterisation and constitutive modelling of peat with reference to landslides. Studia Geotechnica et Mechanica 27(3-4): 67-90.

Long $\mathrm{M}$ and Boylan N (2012) In situ testing of peat - a review and update on recent developments. Geotechnical Engineering Journal of the SEAGS \& AGSSEA 43(4): 41-55.

Maghoolpilehrood F, Disfani MM and Arulrajah A (2013) Geotechnical characteristics of aged biosolids stabilized with cement and lime. Australian Geomechanics 48(3): 113-120.

Maghoolpilehrood F, Disfani MM and Arulrajah A (2014) Geotechnical investigation of stabilised municipal biosolids. In Proceedings of the 20th International Conference on Advances in Civil Engineering for Sustainable Development, Nakhon Ratchasima, Thailand (Horpibulsuk S, Chinkulkijniwat A and Suksiripattanapong C (eds)). School of Civil Engineering, Suranaree University of Technology, Nakhon Ratchasima, Thailand, vol. 2, pp. 431-436.

Maghoolpilehrood F, Disfani MM and Arulrajah A (2015) Geotechnical properties of biosolids stabilised with lime and cement. In Proceedings of the 12th Australia New Zealand Conference on Geomechanics (ANZ 2015), Wellington, New Zealand (Ramsay G (ed.)). New Zealand Geotechnical Society Wellington, New Zealand and the Australian Geomechanics Society, St Ives, New South Wales, Australia, vol. 1, pp. 57-64. Mesri G and Ajlouni M (2007) Engineering properties of fibrous peat. Geotechnical and Geoenvironmental Engineering 133(7): 850-866, http://dx.doi.org/10.1061/(ASCE)1090-0241(2007) 133:7(850).

Metcalf and Eddy, Inc. (2004) Wastewater Engineering: Treatment and Reuse, 4th edn. (Tchobanoglous G, Burton FL and Stensel HD (eds)). McGraw-Hill, New York, NY, USA.

Mitchell JK and Soga K (2005) Fundamentals of Soil Behavior. Wiley, New York, NY, USA.

Moo-Young HK and Zimmie TF (1996) Geotechnical properties of paper mill sludges for use in landfill covers. Journal of
Geotechnical Engineering, ASCE 122(9): 768-775, http://dx. doi.org/10.1061/(ASCE)0733-9410(1996)122:9(768).

Nagaraj HB, Sridharan A and Mallikarjuna HM (2012) Reexamination of undrained strength at Atterberg limits water contents. Geotechnical and Geological Engineering 30(4): 727-736, http://dx.doi.org/10.1007/s10706-011-9489-7.

Nelson DW and Sommers LE (1996) Total carbon, organic carbon, and organic matter. In Methods of Soil Analysis Part 3 - Chemical Methods (Sparks DL (ed.)). Soil Science Society of America and American Society of Agronomy, Madison, WI, USA, pp. 691-1010, http://dx.doi.org/10.2136/ sssabookser5.3.c34.

Novak JT and Calkins DC (1975) Sludge dewatering and its physical properties. Journal of the American Water Works Association 67(1): 42-45.

O'Kelly BC (2004) Geotechnical aspects of sewage sludge monofills. Proceedings of the Institution of Civil Engineers Municipal Engineer 157(3): 193-197, http://dx.doi.org/10. 1680/muen.2004.157.3.193.

O'Kelly BC (2005a) Consolidation properties of a dewatered municipal sewage sludge. Canadian Geotechnical Journal 42(5): 1350-1358, http://dx.doi.org/10.1139/t05-054.

O'Kelly BC (2005b) Sewage sludge to landfill: some pertinent engineering properties. Journal of the Air and Waste Management Association 55(6): 765-771, http://dx.doi.org/10. 1080/10473289.2005.10464670.

O'Kelly BC (2005c) New method to determine the true water content of organic soils. Geotechnical Testing Journal 28(4): 365-369, http://dx.doi.org/10.1520/GTJ11963.

O'Kelly BC (2005d) Mechanical properties of dewatered sewage sludge. Waste Management 25(1): 47-52, http://dx.doi.org/10. 1016/j.wasman.2004.08.003.

O'Kelly BC (2005e) Method to compare water content values determined on the basis of different oven drying temperatures. Géotechnique 55(4): 329-332, http://dx.doi.org/10.1680/geot. 2005.55.4.329.

O'Kelly BC (2006) Geotechnical properties of municipal sewage sludge. Geotechnical and Geological Engineering 24(4): 833-850, http://dx.doi.org/10.1007/s10706-005-6611-8.

O'Kelly BC (2008a) Geotechnical properties of a municipal water treatment sludge incorporating a coagulant. Canadian Geotechnical Journal 45(5): 715-725, http://dx.doi.org/10. 1139/T07-109.

O'Kelly BC (2008b) Effect of biodegradation on the consolidation properties of a dewatered municipal sewage sludge. Waste Management 28(8): 1395-1405, http://dx.doi.org/10.1016/j. wasman.2007.08.004.

O'Kelly BC (2010) Landfill disposal of alum water treatment residues: some pertinent geoengineering properties. Residuals Science and Technology 7(2): 95-113, http://dpi-journals.com/ index.php/JRST/article/view/1371.

O'Kelly BC (2011) Effects of aluminum sulfate and polyelectrolyte solutions on the geotechnical properties of organic clay. Soils and Foundations 51(2): 359-367, http://doi.org/10.3208/sandf. 51.359 . 
Geotechnics of municipal sludges and

residues for landfilling

O'Kelly
O'Kelly BC (2013a) Undrained shear strength-water content relationship for sewage sludge. Proceedings of the Institution of Civil Engineers - Geotechnical Engineering 166(6): 576-588, http://dx.doi.org/10.1680/geng.11.00016.

O'Kelly BC (2013b) Discussion of 'Enhancement of the shear strength of wastewater residuals using industrial waste byproducts'. Journal of Environmental Engineering 139(2): 312-315, http://dx.doi.org/10.1061/(ASCE)EE.1943-7870. 0000608 .

O'Kelly BC (2013c) Atterberg limits and remolded shear strength-water content relationships. Geotechnical Testing Journal 36(6): 939-947, http://dx.doi.org/10.1520/GTJ20130012.

O'Kelly BC (2014a) Characterisation and undrained strength of amorphous clay. Proceedings of the Institution of Civil Engineers - Geotechnical Engineering 167(3): 311-320, http://dx.doi.org/10.1680/geng.11.00025.

O'Kelly BC (2014b) Drying temperature and water content-strength correlations. Environmental Geotechnics 1(2): 81-95, http://dx.doi.org/10.1680/envgeo.13.00016.

O'Kelly BC (2015a) Effective stress strength testing of peat. Environmental Geotechnics 2(1): 33-44, http://dx.doi.org/10. 1680/envgeo.13.00112.

O'Kelly BC (2015b) Atterberg limits are not appropriate for peat. Geotechnical Research 2(3): 123-134, http://dx.doi.org/10. 1680/jgere.15.00007.

O'Kelly BC (2016a) Laboratory permeability determinations for biosolids. Environmental Geotechnics 3(3): 132-139, http://dx. doi.org/10.1680/jenge.15.00026.

O'Kelly BC (2016b) Fall-cone strength testing of municipal sludges and residues. Environmental Geotechnics, http://dx. doi.org//10.1680/jenge. 15.00080 .

O'Kelly BC (2016c) Biodegradation of biosolids and specific gravity determination. Environmental Geotechnics, http://dx. doi.org/10.1680/jenge.16.00014.

O'Kelly BC (2016d) Assessing the shear strength of municipal sludges and residues for landfill disposal. In Proceedings of the 3rd Symposium on Urban Mining and Circular Economy (SUM2016), Bergamo, Italy (Cossu R, Lavagnolo MC and Mudhoo A (eds)). CISA, Padova, Italy (CD-ROM).

O'Kelly BC (2016e) Atterberg limits and peat. Environmental Geotechnics 3(6): 359-363, http://dx.doi.org/10.1680/envgeo. 15.00003 .

O'Kelly BC and Pichan SP (2013) Effects of decomposition on the compressibility of fibrous peat - a review. Geomechanics and Geoengineering 8(4): 286-296, http://dx.doi.org/10.1080/ 17486025.2013 .804210 .

O'Kelly BC and Pichan SP (2014) Effect of decomposition on physical properties of fibrous peat. Environmental Geotechnics 1(1): 22-32, http://dx.doi.org/10.1680/envgeo.13.00012.

O'Kelly BC and Quille ME (2009) Compressibility and consolidation of water treatment residues. Proceedings of the Institution of Civil Engineers - Waste and Resource Management 162(2): 85-97, http://dx.doi.org/10.1680/warm.2009.162.2.85.

O'Kelly BC and Quille ME (2010) Shear strength properties of water treatment residues. Proceedings of the Institution of Civil
Engineers - Geotechnical Engineering 163(1): 23-35, http:// dx.doi.org/10.1680/geng.2010.163.1.23.

O'Kelly BC and Sivakumar V (2014) Water content determinations for peat and other organic soils using the oven-drying method. Drying Technology 32(6): 631-643, http://dx.doi.org/10.1080/ 07373937.2013.849728.

O'Kelly BC and Zhang L (2013) Consolidated-drained triaxial compression testing of peat. Geotechnical Testing Journal 36(3): 310-321, http://dx.doi.org/10.1520/GTJ20120053.

Peck RB (1969) Advantages and limitations of the observational method in applied soil mechanics. Géotechnique 19(2): 171-187, http://dx.doi.org/10.1680/geot.1969.19.2.171.

Raghu D and Hsieh HN (1986) Material properties of water treatment plant sludges. Civil Engineering for Practicing and Design Engineers 5(11-12): 927-941.

Raghu D, Hsieh H-N, Neilan T and Yih CT (1987) Water treatment plant sludge as landfill liner. In Proceedings of Speciality Conference on Geotechnical Practice for Waste Disposal '87, Ann Arbor, MI (Woods RD (ed.)). ASCE, New York, NY, USA, Geotechnical Special Publication no. 13, pp. 744-758.

Ramer DS and Wang MC (2000) Performance of roadway embankment on lime waste. In Geotechnics of High Water Content Materials (Edil TB and Fox PJ (eds)). ASTM, West Conshohocken, PA, USA, Special Technical Publication no. 1374, pp. 351-362, http://dx.doi.org/10.1520/STP14379S.

Ratnayaka DD, Brandt MJ and Johnson K (2009) Twort's Water Supply, 6th edn. Butterworth-Heinemann, Oxford, UK.

Roque AJ and Carvalho M (2006) Possibility of using the drinking water sludge as geotechnical material. In 5th ICEG Environmental Geotechnics: Opportunities, Challenges and Responsibilities for Environmental Geotechnics (Thomas HR (ed.)). Thomas Telford, London, UK, vol. 2, pp. 1535-1542.

Samaras P, Papadimitriou CA, Haritou I and Zouboulis Al (2008) Investigation of sewage sludge stabilization potential by the addition of fly ash and lime. Hazardous Materials 154(1-3): 1052-1059, http://dx.doi.org/10.1016/j.jhazmat.2007.11.012.

Sarsby RW (2005) Geotechnical properties of sewage sludge. In Proceedings of the 16th International Conference on Soil Mechanics and Geotechnical Engineering, Osaka, Japan. Millpress Science Publishers/IOS Press, Amsterdam, the Netherlands, vol. 4, pp. 2327-2329, http://dx.doi.org/10. 3233/978-1-61499-656-9-2327.

Sharma B and Bora PK (2003) Plastic limit, liquid limit and undrained shear strength of soil - reappraisal. Geotechnical and Geoenvironmental Engineering 129(8): 774-777, http:// dx.doi.org/10.1061/(ASCE)1090-0241(2003)129:8(774).

Siedlungsabfall TA (1993) Technische Anleitung zur Verwertung, Behandlung und sonstigen Entsorgung von Siedlungsabfällen (Dritte Allgemeine Verwaltungsvorschrift zum Abfallgesetz). Federal Gazette, 29 May (in German). See http://www.bmub. bund.de/fileadmin/bmu-import/files/pdfs/allgemein/application/ pdf/tasi_ges.pdf (accessed 02/12/2016).

Sivakumar V, O'Kelly BC, Henderson L, Moorhead C and Chow SH (2015) Measuring the plastic limit of fine soils: an 
experimental study. Proceedings of the Institution of Civil Engineers - Geotechnical Engineering 168(1): 53-64, http:// dx.doi.org/10.1680/geng.14.00004.

Skempton AW and Petley DJ (1970) Ignition loss and other properties of peats and clays from Avonmouth, King's Lynn and Cranberry Moss. Géotechnique 20(4): 343-356, http://dx. doi.org/10.1680/geot.1970.20.4.343.

Sorensen KK and Okkels N (2013) Correlation between drained shear strength and plasticity index of undisturbed overconsolidated clays. In Proceedings of the 18th International Conference on Soil Mechanics and Geotechnical Engineering, Paris, France (Delage P, Desrues J, Frank R, Puech A and Schlosser F (eds)). Presses des Pont, Paris, France, vol. 1, pp. 423-428. See http://www.issmge.org/ uploads/publications/1/2/423-428.pdf (accessed 08/11/2016).

Sridharan A and Nagaraj HB (2005) Plastic limit and compaction characteristics of fine soils. Ground Improvement 9(1): 17-22, http://dx.doi.org/10.1680/grim.2005.9.1.17.

Stone KJL and Kyambadde BS (2007) Determination of strength and index properties of fine-grained soils using a soil minipenetrometer. Geotechnical and Geoenvironmental Engineering 133(6): 667-673, http://dx.doi.org/10.1061/ (ASCE)1090-0241(2007)133:6(667).

Stone RJ, Ekwue El and Clarke RO (1998) Engineering properties of sewage sludge in Trinidad. Journal of Agricultural and Engineering Research 70(2): 221-230, http://dx.doi.org/10. 1006/jaer.1998.0266.

Suthagaran V, Arulrajah A, Bo MW and Wilson J (2009) Stabilisation of biosolids with admixtures for potential use as an embankment fill material. Australian Geomechanics 44(3): 63-70.

Terzaghi K, Peck RB and Mesri G (1996) Soil Mechanics in Engineering Practice, 3rd edn. Wiley, New York, NY, USA.

Ukwatta A, Mohajerani A, Setunge S and Eshtiaghi N (2015) Possible use of biosolids in fired-clay bricks. Construction and Building Materials 91: 86-93, http://dx.doi.org/10.1016/j. conbuildmat.2015.05.033.

Ukwatta A, Mohajerani A, Eshtiaghi N and Setunge S (2016) Variation in physical and mechanical properties of fired-clay bricks incorporating ETP biosolids. Journal of Cleaner Production 119: 76-85, http://dx.doi.org/10.1016/j.jclepro. 2016.01.094.

US EPA (US Environmental Protection Agency) (2001) Method 1684: Total, fixed, and volatile solids in water, solids, and biosolids. US EPA, Washington, DC, USA, EPA-821-R-01-015.

US EPA (2015) Biosolids. US EPA, Washington, DC, USA. See https://www.epa.gov/biosolids (accessed 26/07/2016).

Vesilind PA and Martel CJ (1990) Freezing of water and wastewater sludges. Journal of Environmental Engineering 116(5): 854-862, http://dx.doi.org/10.1061/(ASCE)0733-9372(1990)116:5(854).

Voß T (1993) Beitrag zur Festigkeitsentwicklung von Klärschlämmen in Monodeponien. $\mathrm{PhD}$ thesis, Kassel University, Kassel, Germany (in German).

Wang MC and Tseng W (1993) Permeability behavior of a water treatment sludge. Journal of Geotechnical Engineering, ASCE
119(10): 1672-1677, http://dx.doi.org/10.1061/(ASCE)07339410(1993)119:10(1672).

Wang MC, Hull JQ, Jao M, Dempsey BA and Cornwell DA (1992) Engineering behavior of water treatment sludge. Journal of Environmental Engineering, ASCE 118(6): 848-864, http://dx. doi.org/10.1061/(ASCE)0733-9372(1992)118:6(848).

Wanigaratne D and Udamulla L (2012) Mechanically and chemically stabilized bio-solids as embankment fill material. In Proceedings of the 3rd International Conference on Sustainable Built Environment, Kandy, Sri Lanka. Department of Civil Engineering, University of Moratuwa, Moratuwa, Sri Lanka. See http://www.civil.mrt.ac.lk/conference/ICSBE2012/ SBE-12-44.pdf (accessed 24/11/2016).

Wardwell RE, Charlie WA and Doxtader KA (1983) Test method for determining the potential for decomposition in organic soils. In Testing of Peats and Organic Soils (Jarrett PM (ed.)). ASTM, West Conshohocken, PA, USA, Special Technical Publication no. 820, pp. 218-229, http://dx.doi.org/10.1520/STP37344S.

Watanabe Y, Komine H, Yasuhara K and Murakami S (2011) Batch leaching test focusing on clod size of drinking water sludge and applicability to long-term prediction using column leaching test. In Proceedings of Geo-Frontiers 2011: Advances in Geotechnical Engineering, Dallas, TX (Han J and Alzamora DE (eds)). ASCE, Reston, VA, USA, Geotechnical Special Publication no. 211, pp. 1075-1080.

Wichmann K and Riehl A (1997) Mechanical properties of waterwork sludges - shear strength. Water Science and Technology 36(11): 43-50, http://dx.doi.org/10.1016/S02731223(97)00667-7.

Wood DM (1985) Some fall-cone tests. Géotechnique 35(1): 64-68, http://dx.doi.org/10.1680/geot.1985.35.1.64.

Wu TH, Zhou SZ and Gale SM (2007) Embankment on sludge: predicted and observed performances. Canadian Geotechnical Journal 44(5): 545-563, http://dx.doi.org/10.1139/t07-004.

Yesiller N, Hanson JL, Cox JT and Noce DE (2014) Determination of specific gravity of municipal solid waste. Waste Management 34(5): 848-858, http://dx.doi.org/10.1016/j. wasman.2014.02.002.

Zentar R, Abriak NE and Dubois V (2009) Fall cone test to characterize shear strength of organic sediments. Geotechnical and Geoenvironmental Engineering 135(1): 153-157, http:// dx.doi.org/10.1061/(ASCE)1090-0241(2009)135:1(153).

Zhan TL, Zhan Z, Lin W, Luo X and Chen Y (2014) Field and laboratory investigation on geotechnical properties of sewage sludge disposed in a pit at Changan landfill, Chengdu, China. Engineering Geology 170: 24-32, http://dx.doi.org/10.1016/j. enggeo.2013.12.006

\section{HOW CAN YOU CONTRIBUTE?}

To discuss this paper, please submit up to 500 words to the editor at journals@ice.org.uk. Your contribution will be forwarded to the author(s) for a reply and, if considered appropriate by the editorial board, it will be published as a discussion in a future issue of the journal. 